\title{
United States Transuranium and Uranium Registries
}

Washington State University 100 Sprout Road

Richland, Washington 99352

Phone: 509-372-7317

Phone: 1- 800-375-9317 (toll free)

FAX: $509-375-1817$

Web Address: /WWW.tricity.wsu.edu/htmls/ustur/page1.html

\section{ANNUAL REPORT \\ OCTOBER 1, 1994 - SEPTEMBER 30, 1995}

Compiled and Edited by: R.L. Kathren, L.A. Harwick and M.J. Markel 


\section{Dedication}

Since the inception of the Registries in 1968, more than 350 men and women have participated in this research through postmortem donation of tissues. The faculty and staff of the Registries recognize these generous and anonymous contributors to science and dedicate this 1996 Annual Report to their memory. So too is this report dedicated to the memory of two of our scientific colleagues, Dr. Roy C. Thompson (1920-1995) and Professor Robley D. Evans (1907-1995), who during their many years of service as members of the USTUR Advisory Committee provided guidance and support, and who throughout the entire existence of the program, served as colleague, mentor, and friend to the entire faculty and staff. These contributors to this research have earned the respect and admiration of all of us within the Registries family. Through their contributions, our understanding of the biological and health physics aspects of the actinide elements has been greatly facilitated, and we moved closer to achieving a primary goal of the Registries - providing a sound scientific basis for radiation protection standards, thereby assuring their adequacy for the protection of people and the environment. 


\section{DISCLAIMER}

This report was prepared as an account of work sponsored by an agency of the United States Government. Neither the United States Government nor any agency thereof, nor any of their employees, make any warranty, express or implied, or assumes any legal liability or responsibility for the accuracy, completeness, or usefulness of any information, apparatus, product, or process disclosed, or represents that its use would not infringe privately owned rights. Reference herein to any specific commercial product, process, or service by trade name, trademark, manufacturer, or otherwise does not necessarily constitute or imply its endorsement, recommendation, or favoring by the United States Government or any agency thereof. The views and opinions of authors expressed herein do not necessarily state or reflect those of the United States Government or any agency thereof. 


\section{DISCLAIMER}

Portions of this document may be illegible in electronic image products. Images are produced from the best available original document. 


\section{TABLE OF CONTENTS}

Dedication ii

Acronyms and Abbreviations ..........................................................................................ii

Executive Summary ....................................................................................................... 1

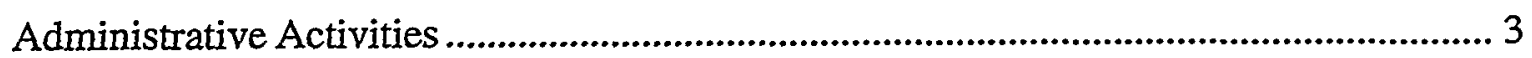

Database, USTUR ….................................................................................................. 7

Figure 1:Registrant database flowchart ......................................................................... 9

Scientific Progress

Cytogenetic Studies and Radiation Carcinogenesis .................................................. 10

Comparing Actinide Concentrations ................................................................................ 14

Figures 2,3:Skeleton:liver plutonium concentration ratios .................................... 17

The Russian-U.S. Registries Collaboration ................................................................ 18

Figure 4:Liver concentration (Bq/kg),USTUR and DRMIA .............................. 20

Estimation of total actinide skeletal content from concentrations in individual bone samples collected at autopsy ............................................................................ 21

Table 1: Whole body skeletal actinide content ........................................................ 24

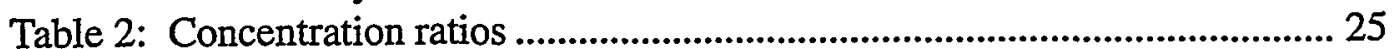

Teeth as an Indicator of Total Skeletal Actinide .......................................................... 26

Table 3: Fraction of skeletal activity in teeth ........................................................ 29

Table 4: Ash concentration ratios......................................................................33

Postmortem Distribution of ${ }^{238} \mathrm{Pu}$ in a Whole Body Donor 18 Years After

Acute Inhalation Exposure................................................................................. 34

Figure 5: ${ }^{238} \mathrm{Pu}$ urinary excretion for USTUR Case 0259 .................................... 38

Tables 5,6: Postmortem ${ }^{238} \mathrm{Pu}$ content of whole body ............................................. 38

A Study of Actinide Microdose Distribution in Selected Bones Using Electron

Paramagnetic Resonance (EPR) .......................................................................... 39

Figure 6: First derivative EPR spectra of unirradiated bone, etc. ......................... 40

Radiochemistry Operations .............................................................................................. 41

Appendices

Appendix A Policy and Procedure Manual Table of Contents .......................................... 45

Appendix B Functional Organization Chart ...................................................................... 46

Appendix C Staff Photographs ............................................................................................ 47

Appendix D Advisory Committee Report .......................................................................... 51

Appendix E Publications and Presentations ........................................................................ 61

Appendix F Projects in Progress ......................................................................................... 68

Appendix G Radiochemical Intercomparisons ................................................................. 72

Appendix H Distribution List ....................................................................................... 99 


\section{ACRONYMS AND ABBREVIATIONS}

ACHRE Advisory Committee on Human Radiation Experiments

AF $\quad$ activity fraction

AMAD Activity median aerodynamic diameter

CEDR Comprehensive Epidemiological Data Resource

CR concentration ratios

DNA deoxyribonucleic acid

DRMIA Dosimetry Registry of the Mayak Industrial Association

EPA Environmental Protection Agency

EPR electron paramagnetic resonance

FISH fluorescence in situ hybridization

GPA glycophorin-A

HEHF Hanford Environmental Health Foundation

ICD-9 International Classification of Diseases-9th Revision clinical Modification

ICRP International Commission on Radiological Protection

LANL Los Alamos National Laboratory

NHRTR National Human Radiobiology Tissue Repository 
NIST National Institute of Standard and Technology

OSTI Office of Scientific and Technical Information

PHA phytohemagglutinin

PNNL Pacific Northwest National Laboratory

RBC red blood cells

RES reticuloendothelial system

RNA ribonucleic acid

USTUR United States Transuranium and Uranium Registries

UW University of Washington

WSU Washington State University

WWW World Wide Web 
$\frac{\$}{0}$

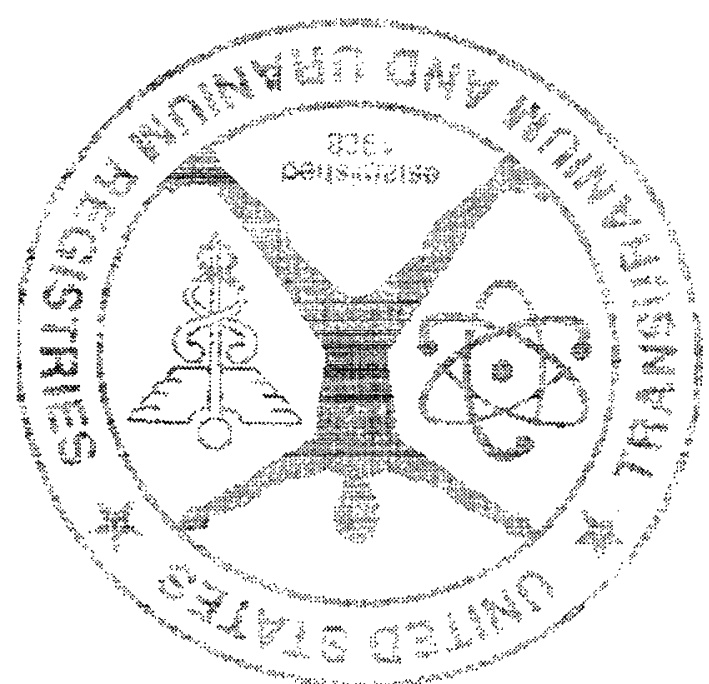




\section{Executive Summary}

This report documents the activities of the United States Transuranium and Uranium Registries for the year October 1, 1994 through September 30, 1995. Administrative accomplishments during the year included the publication of a new brochure, the Annual Newsletter and renewal of all active Registrants. Records and files were microfilmed and the microfilmed duplicates were stored in a protected location in the campus library. In response to a request from the President's Advisory Committee on Human Radiation Experiments, the Registries provided information and specific documentation pertaining to human subjects considerations. The Registries program was found to be ethically sound and in full compliance with all applicable regulations.

A Registries home page was created on the World Wide Web. In addition to general information about the Registries program, it includes summaries of the two most recent Annual Reports; a list of publications; and access to the Registries database. The Registries home page address is www.tricity.WSU.edu/htmls/ustur/page1.html. Considerable progress was made with respect to computerization of the database; the data base now includes, in addition to the administrative information on all registrants, radiochemical results for all tissues collected at autopsy and health physics information including radiourinalysis results and other dosimetry data for all deceased registrants. In progress are a table of the health history for all registrants and a clinical history table.

During the reporting period, Registries staff authored or coauthored more than 45 scientific papers or abstracts published or submitted for publication in the open peer reviewed scientific literature and presented more than two dozen scientific papers, seminars, and public presentations. The Director was named Hartman Medalist and Orator by the Radiology Centennial and was also the recipient of the Herbert M. Parker Award.

The radiochemistry laboratory became fully operational with primary effort devoted to reduction of the sample backlog received from Los Alamos National Laboratory and to quality assurance. Quality assurance intercomparisons with the University of Washington and Los Alamos National Laboratory were carried out and revealed no indications of random or systematic error.

Evaluation of USTUR Case 0259 , a whole body donor who had incurred an acute inhalation intake of high fired ${ }^{238} \mathrm{PuO}_{2} 18$ years prior to death, revealed a systemic distribution pattern of the 238 isotope of plutonium not significantly different from that observed for ${ }^{239} \mathrm{Pu}$. About half the total body burden of ${ }^{238} \mathrm{Pu}$ was found in the liver, but only 37 per cent in the skeleton. There was, however, considerably less activity in the respiratory tract than would be expected on the basis of current models, and this observation, coupled with the urinary excretion pattern observed during life, are indicative of more rapid clearance of 
the 238 isotope from the respiratory tract as compared with ${ }^{239} \mathrm{Pu}$, likely attributable to particle breakup because of the higher specific activity and consistent in this regard with what has been observed in animal studies.

Examination of tissue concentration ratios for both plutonium and americium in Registries cases as a function of time after intake suggests that there are no significant differences in the retention half-time among the various soft tissues as compared with the liver. Teeth were evaluated as a means of estimating total skeletal content of plutonium or americium. No consistent relationship was found between plutonium and americium concentration or content in the teeth and in the skeleton as a whole. The activity concentration in certain bones, notably the ribs, was found to be a constant fraction of the average skeletal concentration, and these bones can thus be used to estimate total skeletal content of actinide making appropriate assumptions relative to the mass of the skeleton.

Cytogenetic studies were initiated utilizing glycophorin-A and fluorescence in situ hybridization techniques to examine circulating red blood cells in persons with a known history of exposure to the actinide elements with the ultimate goal of utilizing stable chromosome changes to quantify exposure to the actinide elements.

The feasibility study was completed for joint USTUR-Russian research collaboration. This work documented the similarities and differences between the Registries of the two countries and a plan was developed for future effort. 


\section{ADMINISTRATIVE ACTIVITIES}

\section{Lynn A. Harwick and M. June Markel}

\section{Microfilming}

This year the Registries secured the funding necessary to microfilm all Registrant and related records. Each individual record was microfiched and is kept with the physical files in a secured room in the USTUR building. Another microfilmed copy is stored in the Max E. Benitz library at WSU in Richland. Although the microfilm is stored in the library, it is unavailable for public use since it contains personal identifiers and other information that requires protection in accordance with state and federal law. The records will be microfilmed periodically to ensure they are kept current and accurate.

Many benefits have been gained through the completion of the microfilming. Registries faculty and staff now have an extra copy of Registrant data for scientific and administrative use. Previously, only one staff member could use a particular file. It has also provided the security of having an additional copy in the event of a fire or natural disaster which may destroy documents significant to the Registries research. Additionally, the microfilming process actually added clarity to many of the older documents which were difficult to read due to fading.

\section{Advisory Committee Meeting}

The annual USTUR Advisory Committee Meeting was held October 17-18, 1995 at the University Inn in Moscow, Idaho. The meeting was attended by the USTUR Advisory Committee, USTUR staff, and others associated with the pro- gram. All Advisory Committee members were in attendance: Keith Schiager, Advisory Committee Chairman; Borje $\mathrm{K}$. Gustafsson, Kenneth G. W. Inn, George L. Voelz, Bruce Lawson, MaryBelle Thompson and the newly appointed Robert Thomas, recently retired from Argonne National Laboratory. The report of the Committee is included as an Appendix D.

The meeting was held in Moscow, Idaho which borders Pullman, Washington to allow meeting attendees to tour the recently remodeled radiochemical laboratory in the Nuclear Radiation Center on WSU's main campus where radiochemical analyses in Registries research formerly performed by the Los Alamos National Laboratory (LANL) are now carried out.

\section{Color Brochure}

A full-color information brochure on the Registries was printed and distributed. The brochure combined the information contained in the first USTUR brochure and that in the document formerly known as "Questions and Answers" about the USTUR. Charles Powell, Information Coordinator for the WSU College of Veterinary Medicine, and the USTUR Advisory Committee assisted with editing the material into an easily read and non-technical format.

The brochure provides an overview of the USTUR and the National Human Radiobiology Tissue Repository 
(NHRTR). It also briefly discusses the research interests of the program and how post-mortem tissue donations are obtained. Inside the brochure is a postage paid business reply card which can be returned to the USTUR to request further information about the program.

\section{Human Subjects Review}

As noted in the 1994 Annual Report, all research programs at WSU which use human subjects must be granted approval by the WSU Institutional Review Board (IRB). The USTUR which was initially granted approval by the IRB in February, 1992, and again this year received approval for continued research involving human subjects in 1995. No changes were recommended by the IRB.

\section{Manuscript Tracking System}

Due to rapid programmatic growth and the addition of the radiochemistry operations last year, a significant increase in publications has arisen necessitating the establishment of a manuscript tracking system. Each manuscript receives a tracking number in the following format: USTUR-\#-YY.

The five letters identify the program and are followed by a unique four-digit number, with the last two digits corresponding to the year of publication. Once a number is assigned, a file is established and the publication is either submitted to a peer-reviewed journal or to the Office of Scientific and Technical Information (OSTI).

Persons interested in receiving a publication registered with OSTI can request a copy from the Office of Scientific and
Technical Information, P.O. Box 62, Oak Ridge, TN 37831, as well as directly from the Registries, although supplies from the latter source are limited.

\section{Registrant Newsletter}

The second registrant newsletter was published and mailed in December to all currently active Registrants. Once again, the newsletter highlighted USTUR activities for the past year and gave Registrants the opportunity to see how their participation is essential to the continued research of the Registries. The newsletter also gives the Registries an opportunity to extend season's greetings to several hundred program Registrants located in various parts of the country.

\section{New Phone System for the campus}

WSU installed a new phone system this past Fall. The system allows anyone on any WSU campus to reach any of the other WSU campus by dialing a five-digit number. This is not only more convenient, but toll-free as well. In the past, the phone number had to be dialed in its entirety and there was a long-distance charge for each call. The system has also brought voice mail to the campuses and several new features which bring WSU into the "communications 90's."

Prior to the switch to the new phone system, the Richland campus received all new phone numbers. Previously the prefix was 375-9XXX, but was changed to $372-7 X X X$ in anticipation of the new system.

\section{6-6010 Disconnect}

As mentioned in the previous Annual Report, the Registries now has an 800 telephone number which is replacing the 
hotline which was formerly used to place collect calls to the USTUR. If you dial the hotline at (509)376-6010, you will hear a recorded message that refers you to the new 800 number, (800)375-9317. This number is toll-free and was established for the use of Registrants, their families, and caretakers as well as others who may have questions or need more information about the Registries.

The recording will eventually be disconnected, so please make note of the new 800 number.

\section{Advisory Committee on Human Radia- tion Experiments (ACHRE)}

ACHRE was created by President Clinton to evaluate the history and policies of human radiation experiments carried out or sponsored by the U.S. Government. As part of their evaluation, ACHRE began a Research Proposal Review Project in which several programs funded by various federal agencies were selected and asked to provide specific documentation pertaining to their human subjects research approval. The USTUR provided this information as well as offered copies of the Registries' pertinent policies and procedures. The Registries program was found to be ethically sound and in complete compliance with all applicable regulations.

\section{Registrant Renewal 1994-95}

After the 1993 audit review of all Registrant files, it was concluded that a mass renewal of Registrant agreements was required. Historically and prior to the transfer of the Registries, the participants in the tissue donor program were renewed every five (5) years with the date of deter- mination for renewal being the date the completed forms were signed by the Registrant and accepted by the Registries. This method, while previously adequate, was inefficient and incompatible with the modern automated system at Washington State University. The Registrant renewal began with a mass mailing to all active Registrants regardless of the donor expiration date.

A comprehensive review of the Registrant files indicated that a majority were not complete, lacking medical and health physics information on virtually every active case. Prior to the 1992 Registries transfer to WSU, standard practice was to request medical and dosimetry records after death and at the time of tissue analysis. However, to gain information necessary to determine whether Registrants met the criteria for enrollment in the Registries, it was decided that information should and would be requested prior to acceptance of the enrollment forms. This task compounded the renewal by slowing down the process, adding a financial and time burden to former Registrant employers faced with a dwindling medical and dosimetry workforce and in some cases, outright refusal by the employer to release medical and dosimetry records.

As a result of the renewal, a number of improvements have been implemented including color coding of the file labels which gives instant recognition of Registrant status and minimizes the possibility of completing incorrect documentation at the time of a death.

\section{The Long Range Plan}

The future development, growth and 
USTUR have been identified in the Long Range Plan 1996-2005. These include contributions of interests and vision by Registries staff members as well as suggestions put forth by the Advisory Committee in previous years. A copy of this document is available and can be requested directly from the USTUR or by writing to OSTI, as instructed in the Manuscript Tracking System. The tracking number for the Long Range Plan is \#USTUR0040-95.

\section{Record Archives}

Review of the archival records and files transferred from HEHF indicated a need to implement an alpha-numeric coding system to access information, not required in the every day functions of the office but valuable as historical information on the Registries and other entities involved with the inception and continued effort. This task was tabled until the Renewal was completed and has now been reactivated. 


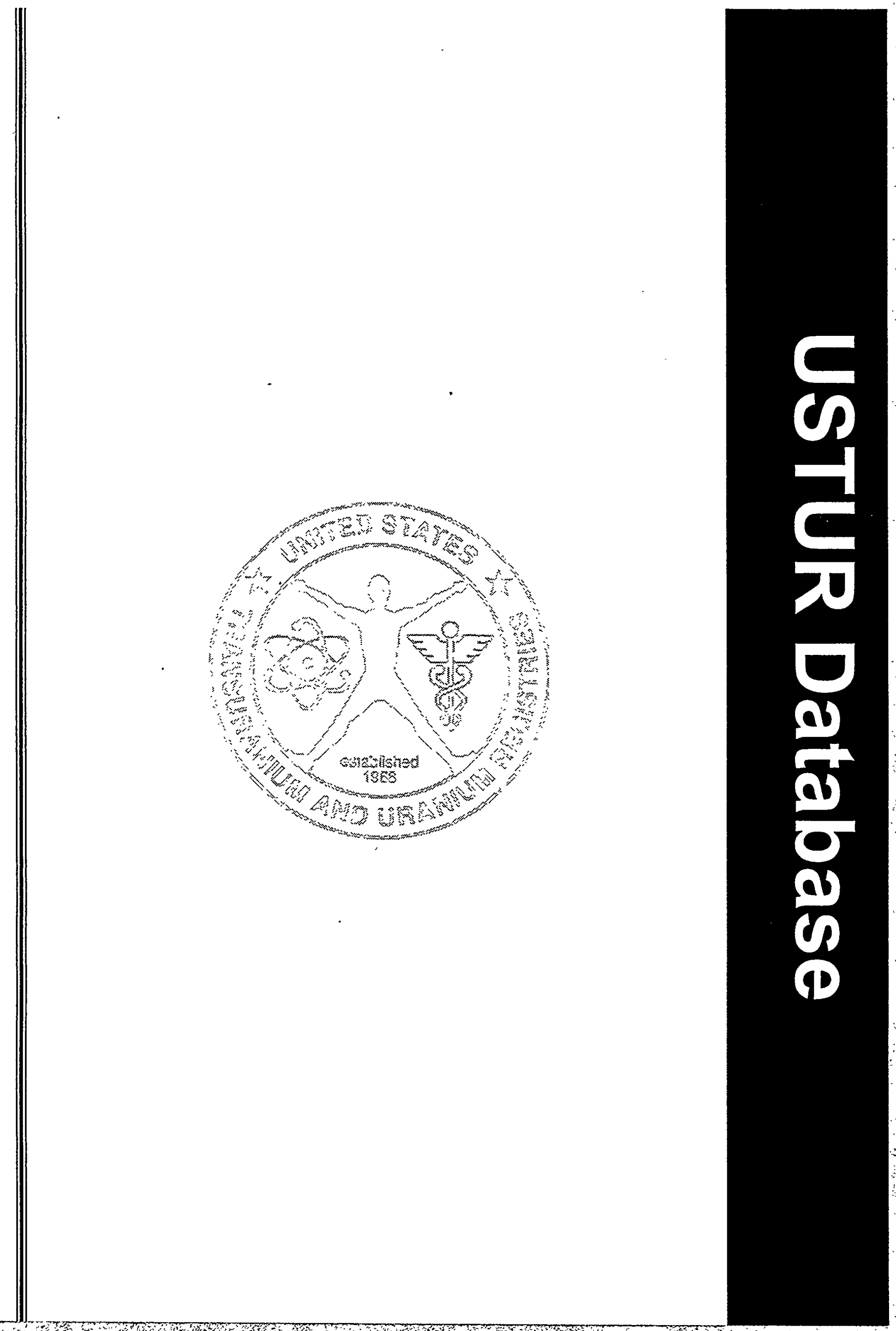




\section{USTUR DATABASE}

\section{Minh V. Pham}

\section{Introduction}

During fiscal year 1995, notable progress was made with the USTUR database system, which has been modernized to eliminate software and format incompatabilities and now utilizes a unified standard format. The improved high reliability and consistency of the data not only facilitates statistical analyses, but enables certain mathematical and other procedures to be carried out expeditiously and with a previously unattainable degree of accuracy. Several major database files have been completed, and at the same time supplementary database files continue to be developed to accommodate the growing needs of the Registries. Much of the data has also been made readily accessible to the scientific community both nationally and internationally through the Registries' homepage on the World Wide Web and the Comprehensive Epidemiologic Data Resource (CEDR).

\section{Database Files}

The three main files in the USTUR database are labeled Radiochemical, Health Physics, and Medical. The first two files are complete and contain large volumes of data which are regularly updated, while the Medical file is still under development.

The Radiochemical file contains basic file information about radiochemical analysis of tissue donations from USTUR registrants. These data were originally collected from a number of sources, primarily national laboratories. Because of dif- ferences in the data collection protocols for the various sites, it was necessary to convert the data into a consistent format which was accomplished using the commercially available PARADOX For Windows software. The data generated from the radiochemical laboratory in Pullman have also been incorporated into the USTUR database. Additional data are routinely integrated into the system as it is received from the laboratory.

The Health Physics file contains bioassay and other health physics data and was the second major database file to be completed. This file contains about 14,000 registrant records including external dose assessments and information, and results of excreta analysis and in vivo counting. Although there was a large volume of records, all those existing have been inputted and will continually be updated. To ensure quality control, the data are also cross-checked for accuracy.

The Medical file contains both personal and clinical data and is currently being developed. To remain consistent and be able to share data with other research institutes. the file has been created utilizing ICD-9 CM Coding, a world recognized standard medical format which is commonly used for medical data coding. The personal data have been entered and input of the analyzed data has continued through this reporting period.

Figure 1 illustrates the workings and accountabilities of cognizant Registries' 
staff with regard to the USTUR database.

\section{World Wide Web}

The Registries now have a homepage on the World Wide Web. This new technology has allowed the Registries to make the entire electronically formatted database available through CEDR. In addition to data, the homepage also allows users to access Registries' information such as annual reports, publications, and the program's history which all can be downloaded. Comments and questions can be sent to the Registries through the homepage, and inquiries will be responded to via computer or mail. The Registries home page is linked to the Washington State University home hage, and the CEDR home page.

USTUR World Wide Web address is: http://www.tricity.wsu.edu/htmls/ustur/page1.html 
Figure 1. USTUR Registrant Database Flowchart

\section{USTUR Registrant Database Flowchart}

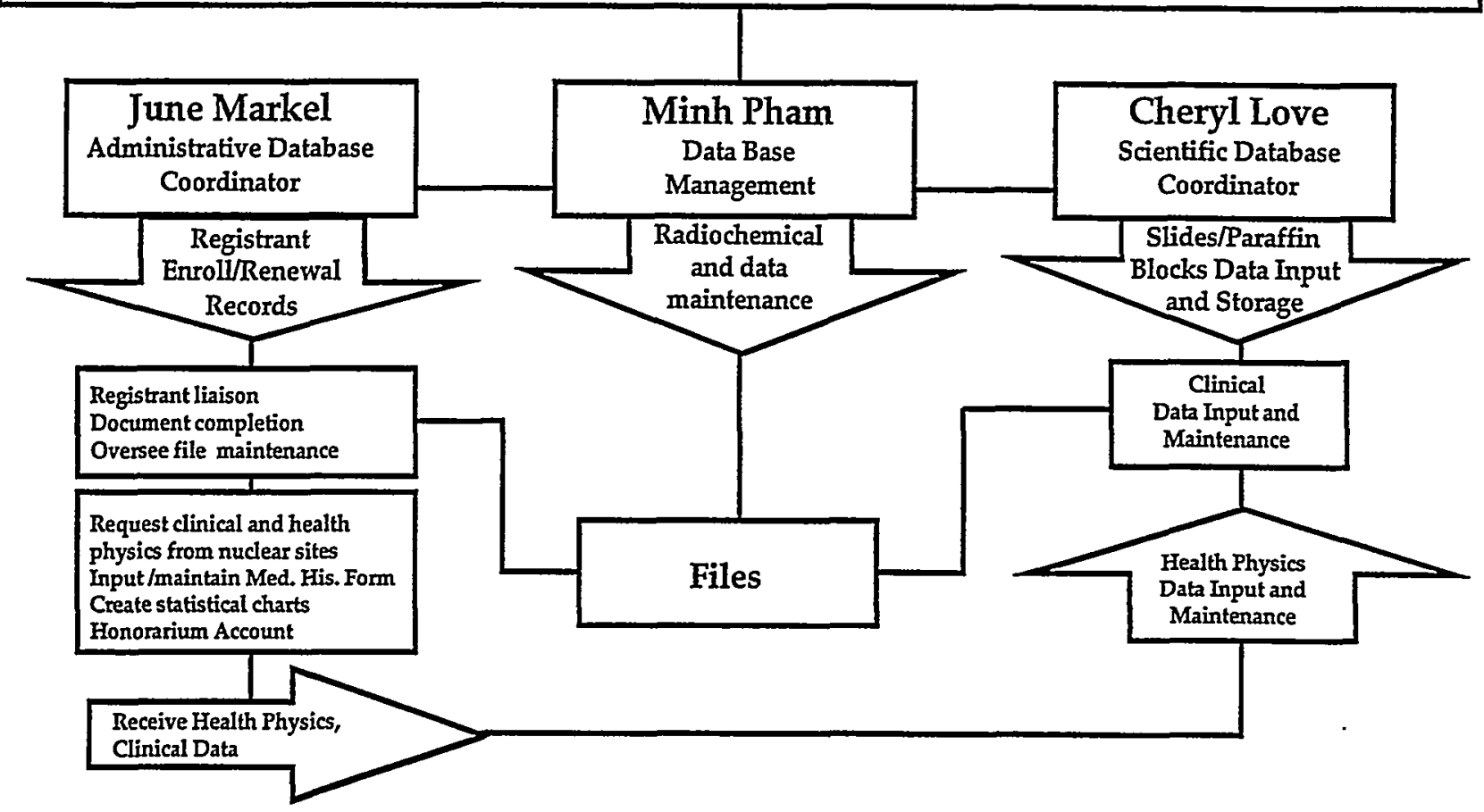




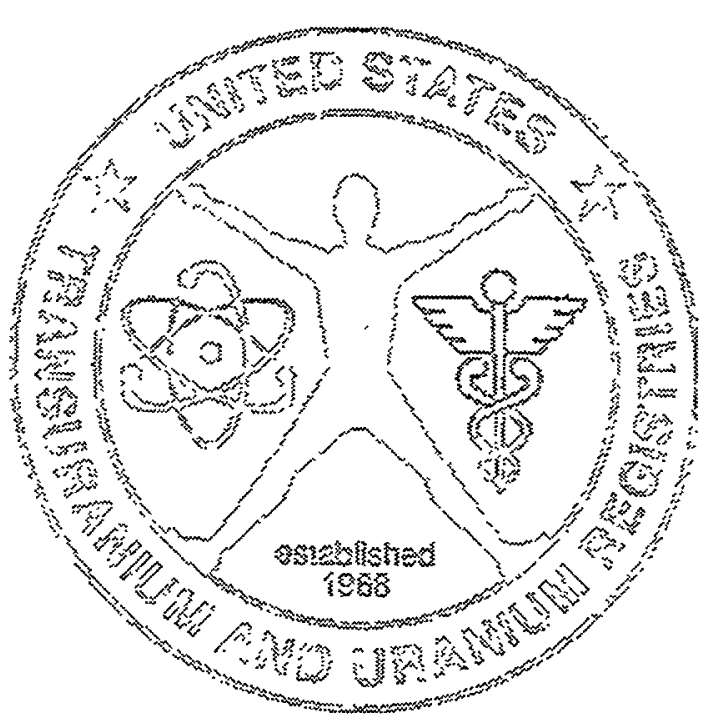

$\infty$

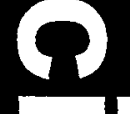

(D)

$\square$

.

争

?

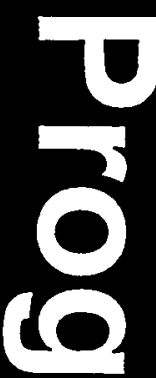

2

(1)

a

$\omega$ 


\section{CYTOGENETIC STUDIES AND RADIATION CARCINOGENESIS}

Principal Faculty Investigator: John J. Russell

It has become increasingly apparent that the development of a tumor involves a number of specific mutations including deletions of partial or entire chromosomes. From studies using chemical carcinogens, certain oncogenes have been associated with phenotypic changes of transformation. It is not known which oncogenes are responsible for radiation-induced transformation, but numerous studies have demonstrated that agents other than ionizing radiation can cause neoplasia via a series of steps. These steps are identified as initiation, promotion, and progression and suggest that similar steps may be involved in radiation tumorigenesis as well. Thus, in addition to identifying which and how many oncogenes may be involved and in what manner they become activated, it is also essential to know what role they play in the overall carcinogenic process.

Whether in human or animal tissue, it is clearly impossible to distinguish a tumor or neoplasm induced by ionizing radiation from one that occurs spontaneously. Radiation induced neoplasms are identified in a population study by calculating the difference between the background frequency of spontaneous tumors and the excess rate (BEIR IV). It is also equally true that neoplasms can be induced in virtually any tissue or organ of the body if the exposures are appropriate; however, there are significant differences in the oncogenic potential of irradiation in different tissues.
Radiation is generally accepted as a complete carcinogen in that a single exposure can induce neoplasia. Many combinations of physical and chemical agents can have varying degrees of effects on carcinogenesis. Their interactions can be additive, synergistic, or multiplicative. Several studies have shown radiation serving as the second event in the multi-step process of oncogenesis after initiation by other means.

The value of tissue specimen banking projects such as those at National Institute of Standards and Technology (NIST) and the Environmental Protection Agency (EPA) have provided baseline environmental data for monitoring chemical toxicant trends over time and among different sites, and provided samples for reanalyses as well as samples for retrospective analysis with new and or improved techniques. They have also helped to evaluate the stability of biological samples and environmental pollutants in archived or long-term storage. These advantages and numerous others can be obtained from the use of human tissue samples archived in the NHRTR.

In addition to the traditional studies of organ retention, dosimetry, microdosimetry, and biokinetic modeling, the Registries' research efforts have expanded into other areas, including studies of radiation carcinogenesis and exposures to mixed hazardous wastes. Thus, we be- 
lieve that additional analyses of these archival samples for such things as hazardous chemicals i.e. halogenated hydrocarbons, heavy metals, asbestos, or other toxic compounds frequently encountered in the work place, will provide valuable information. This information regarding the level and type of interactions produced in combination with radiation, and whether or not the combination of exposures are more deleterious than either alone, could be very significant.

The importance of gross chromosomal changes has been recognized and valued in the very recent past as a marker for cellular damage. New techniques for characterizing chromosomes have been developed that allow whole or pieces of chromosomes to be identified and the subsequent loss, partial deletion, or rearrangement of chromosomes in tumors to be examined. The emergence of new and improved biodosimetric techniques have made it possible to evaluate a radiation worker in new ways never before possible. In addition, these biodosimeter techniques can be used to augment or challenge official dosimetry record information maintained during employment.

Two such biodosimeter techniques, glycophorin-A (GPA) and fluorescence in situ hybridization (FISH), detect somatic mutations and chromosome translocations that are stable with time post-exposure and integrate radiation damage from chronic radiation conditions. Two other techniques, micronuclei and dicentrics, are unstable and only detect relatively recent radiation exposures.

The first one, GPA, detects mutations in the GPA gene of bone marrow euthyroid precursor cells that produce variant peripheral blood erythrocytes that fail to express a normal form of GPA. The FISH assay was developed to detect chromosome translocations in peripheral blood lymphocytes using in situ hybridization of chromosome-specific DNA probes. The in situ hybridization technique has become a very powerful and versatile tool for detecting and localizing nucleic acid (RNA or DNA) sequences within cell nuclei of tissue sections or cell preparations. The sub cellular target i.e., chromosome translocation, is detected by the hybridization of a complimentary probe that has been labeled with a fluorescent dye with the tissue section or cell preparation. For these studies, a heparinized blood sample is cultured with phytohemagglutinin (PHA) to stimulate the growth of $\mathrm{T}$ lymphocytes which are then arrested in metaphase by colcemide treatment.

GPA is a cell surface sialoglycoprotein of red blood cells (RBC). For the GPA assay, a heparinized blood sample is fixed and the RBC's are labeled with monoclonal antibodies and analyzed on a flow cytometer. The assay is used to determine the frequency of RBC's lacking the expression of one of the allelic forms of the cell surface protein GPA that may have resulted from a mutation induced in the GPA locus in bone marrow erythroid precursor cells.

In an effort to expand understanding of the effects of radiation exposures in humans, the Registries are set to pursue, identify, and quantify the cytogenetic aberrations, both induced and spontaneous, in existing living registrants who are cur- 
rently identified as long range follow-up study participants. To perform the outlined studies above, we will use a 10-15 $\mathrm{ml}$ blood sample from each participant, collected twice a year to accommodate seasonal variations. The blood samples will be collected by independent qualified medical personnel using routine procedures and safety precautions.

\section{Selected Future Studies}

To understand radiation-induced carcinogenesis, it is necessary to identify the specific genes responsible for the initiation, promotion, and progression events of the multi-step carcinogenic process. Currently, there are approximately 100 oncogenes that can, if they malfunction, cause uncontrolled cell growth. Conversely, there are at least six known genes that suppress the growth of potential cancer cells. How ionizing radiation affects genes and gene expression is a hotly debated issue and a highly promising area for Registries related research. Accordingly, the Registries, through the NHRTR, has initiated collaborations with other investigators. Specific study areas include:

1. Iteration or deletion of genes such as $c$ - myc, that function in cell proliferation, differentiation, and tumor promotion.

2. The relationship of $p 53$ and the retinoblastoma gene in the development of bone tumors.

3. The development of biological dosimeters or biomarkers for retrospective dosimetry such as electron spin resonance (ESR) of tooth enamel, FISH for the detection of gene translocations, and glycophorin-A analysis for somatic mutation detection.

4. Whether one or all of the above are dose and or dose-rate related.

5. Mixed hazardous wastes exposure-induced health effects incurred from accidental exposures received during site cleanup activities.

6. The induction of micronuclei in deep lung epithelial cells as a model for radiation sensitivity of the respiratory tract.

A number of the study areas listed above are currently under active investigation with collaborative institutions and will be reported in the near future. However, the successful development of much needed in vitro cell culture methodology to grow and maintain deep lung and nasal epithelial cells has been accomplished in collaboration with scientists at Battelle Pacific Northwest National Laboratory (PNNL). These techniques are being used to investigate the relationship between cancer induction and cytogenetic instability induced by radiation exposure. Results from these initial studies were discussed in two papers presented at the 12th Annual Meeting of the Pacific Northwest Association of Toxicologists, September 1516, 1995 in Moscow, Idaho. The presentations were made by Registries faculty member Shiping Bao and were entitled, Induction of Micronuclei In The Respiratory Tract Following Exposure To ${ }^{60} \mathrm{Co}$ Gamma Rays and Use of Cellular Damage To Determine The Relationship Between Exposure And Dose From Inhaled Radon. 
Availability of NHRTR Tissue Samples

The unique materials of the NHRTR are available to investigators for research purposes. Any scientific investigator may request NHRTR tissues or tissue samples by writing to the Registries. Investigators agree to maintain the privacy of the cases and follow all legal requirements as well as the published policies of the Registries. If available, the Registries will provide the most suitable tissue requested, e.g. frozen, formalin-fixed, or dried. In addition, if the radiochemical data are known at the time of the request, it will be provided as well. The only stipulation is that the Registries be acknowledged as the source of the samples or radiochemical data used in scientific proposals or manuscripts submitted for publication. Scientific collaboration with the Registries scientific staff is encouraged.

\section{References}

National Research Council. Committee on the Biological Effects of Ionizing Radiations (BEIRIV). Health risks of radon and other internally deposited alpha-emitters. Washington, DC: National Academy Press; (1988). 


\section{COMPARING ACTINIDE CONCENTRATIONS IN THE SKELETONS AND LIVER OF USTUR ROUTINE AUTOPSY CASES}

\section{Principal Faculty Investigator: Ronald E. Filipy}

In the USTUR annual report for 1994, the report of progress in actinide biokinetic investigations was focused on several soft tissues of the body (Kathren and Harwick 1995); the results of that investigation were recently published (Filipy and Kathren 1996). The skeleton and the liver are the major deposition sites of actinide elements in the body and they are of primary concern for radiation protection purposes because, next to the lungs, they are the organs of highest risk for radiation-induced biological changes including cancer. Therefore, deposition and retention of the actinides in those two organs are the focus of this report. As indicated in another section of this report (Filipy 1996), the Dosimetry Registry of the Mayak Industrial Association (DRMIA) has collected similar human tissue data from Russian plutonium workers and some of these data were included in the analysis.

Initial systemic depositions of actinides in most USTUR cases can only be roughly approximated from urinalyses, fecal analyses, and/or whole body counting; therefore, estimates of the contents of individual organs, initially or at any given time after exposure, are highly uncertain. Such information is necessary for characterization of clearance rates from individual organs, as well as for accurate dose estimation, which in turn is crucial to epideimiologic and risk and effects studies. A useful means of circumventing that problem is to compare concentration ra- tios of the organs with residence times (times between exposure and death).

Skeleton-to-liver ${ }^{239+240} \mathrm{Pu}$ and ${ }^{241} \mathrm{Am}$ concentration ratios were calculated and plotted as a function of residence times in Figures 2 and 3 , respectively. Also shown in the figures are regression lines through the observed data and lines representing concentration ratios calculated by ICRP67 methodology (ICRP 1994). There is a notable difference between the magnitude of the concentration ratios of plutonium and americium. Most ratios of plutonium are in the range between 0.05 and 1.0 while those of americium are generally between 0.1 and 10.0. This indicates greater deposition and retention of americium than plutonium in the skeleton; or less americium than plutonium in the liver; or both, not surprising in light of previous reports that arrived at the same conclusions (ICRP 1986; Kathren et al. 1988; McInroy et al. 1989; Kathren 1994).

For plutonium (Fig. 2), the regression line and the model-predicted lines are very nearly parallel for the entire range of residence times. The slight positive slope of the lines suggests that the retention halftime of the liver is slightly shorter than that of the skeleton although the slope of the regression line was not significantly different from zero which would indicate no difference in retention half-times in the two organs. The ratios calculated by the ICRP technique are about 1.5 times greater than 
those of the regression line which suggests that the ICRP model predicts a slightly greater than observed skeletal concentration or a slightly less than observed liver concentration, or both. Because of the variability in the observed data, there is not a statistically significant difference between the ICRP model and the regression line through the observed data. It is noted, however, that approximately three-fourths of the observed skeleton:liver concentration ratios are smaller than the ratios calculated by the ICRP technique.

For americium (Fig. 3), the modelpredicted line is higher than the regression line through the observed data by approximately a factor of two with residence times greater than $10 \mathrm{y}$. Again, the variation in data probably precludes any statistical difference between the lines although it is apparent that the majority of observed data points are below the ICRP-predicted concentration ratios. The slope of the regression line through the observed skeleton:liver americium concentration ratios was nearly the same as that for the plutonium ratios although, again, the slope was not significantly different from zero.

One possible explanation for the differences between the model-predicted lines and the regression lines, if the differences are in fact real, might be in the mode of exposure. Approximately one-third of the USTUR cases had no recorded exposure incidents or positive bioassays during the time they worked with actinides, yet they had actinide body burdens at death which indicates very low-level, chronic exposure and the ICRP models are based on acute exposures. Also, most USTUR and DRMIA exposures were by inhalation of relatively insoluble forms of plutonium so the systemic uptake from the lungs would be expected to occur over a long period of time. The effect of acute versus chronic intakes on actinide biokinetics is not known.

The ICRP models are primarily based on animal experimental data with a very limited amount of human data, largely from short-term experiences. The data shown in Figs. 2 and 3 suggest that some adjustment to the models might be appropriate to more closely align with observed, long-term human data.

\section{References}

Kathren, R.L., L. A. Harwick, R. E. Toohey, J. J. Russell, R. E. Filipy, S. E. Dietert, M. M. Hunacek, and C. A. Hall. Annual Report of The United States Transuranium and Uranium Registries, October 1, 1994-September 30,1995. USTUR-0049-95 (1996).

Filipy, R. E. and R.L. Kathren. Changes in soft tissue concentrations of plutonium and americium with time after human occupational exposure. Health Phys. 70:153-159 (1996).

International Commission on Radiological Protection. The metabolism of plutonium and related elements. ICRP Publication 48; Ann. ICRP 16(2/3):1-98 (1986).

International Commission on Radiological Protection. Age-dependent doses to members of the public from intake of radionuclides. ICRP Publication 67. Ann. ICRP 23(3/4):1-167 (1994). 
Kathren, R. L., J.F. McInroy, M.M. Reichert, and M.J. Swint. Partition ing of ${ }^{238} \mathrm{Pu},{ }^{239} \mathrm{Pu}$, and ${ }^{241} \mathrm{Am}$ in skeleton and liver of U. S. Transuranium Registry autopsy cases. Health Phys. 54:181-188 (1988).

Kathren, R. L. The United States Transuranium and Uranium Registries, a twenty-five year report: Toward improved biokinetic models for actinides. Radiat. Prot. Dos. 53:219-227 (1994).

Kathren, R. L. and L.A. Harwick. eds. Annual Report of the United States Transuranium and Uranium Registries. October 1, 1993 - September 30, 1994. Washington State University. USTUR0036-95:69 (1995).

McInroy, J. F., R.L. Kathren, and M.J. Swint. Distribution of plutonium and americium in whole bodies donated to the United States Transuranium Registry. Radiat. Prot. Dos. 26:151-158 (1989). 
Figure 2. Skeleton: liver plutonium concentration ratios as a function of estimated time between exposure and death (residence time) in USTUR and DRMIA cases, including the predicted ratios calculated by ICRP (1994) methodology and the regression line through the observed data.

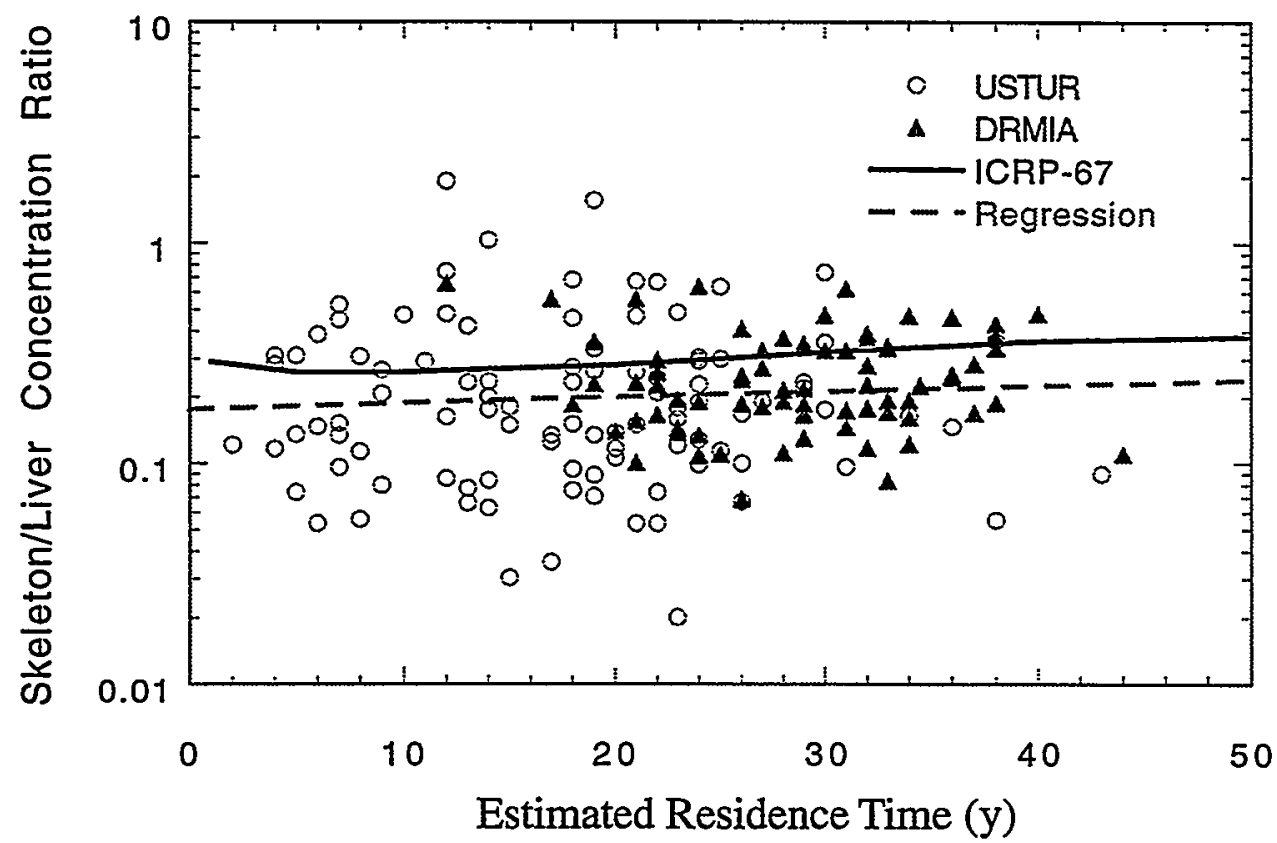

Figure 3. Skeleton: liver americium concentration ratios as a function of estimated time between exposure and death (residence time) in USTUR and DRMIA cases, including the predicted ratios calculated by ICRP (1994) methodology and the regression line through the observed data.

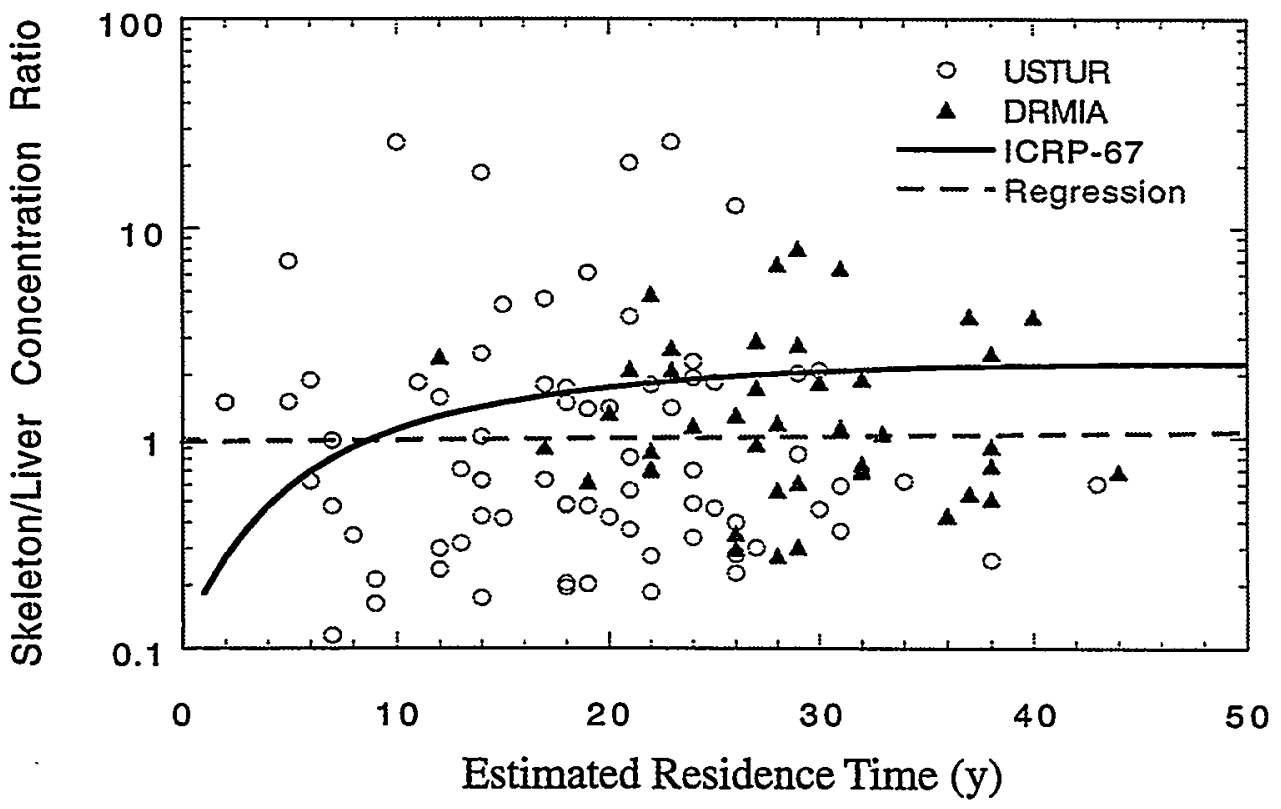




\section{THE RUSSIAN-U.S. REGISTRIES COLLABORATION}

\section{Principal Faculty Investigator: Ronald E. Filipy}

Scientists of the First Branch of the Russian Institute of Biophysics have been collecting autopsy and human tissue analytical data nearly as long as the USTUR has been operating. The Russians have concentrated mainly on occupationallyexposed plutonium workers from Mayak, the Russian plutonium production facility.

In January, 1995, USTUR Professor Ronald E. Filipy attended a scientific symposium at Chelyabinsk, Russian Federation (140 km from Mayak) and presented a paper entitled "Estimation of Actinide Element Biokinetics and Organ Doses in Humans on the Basis of a Limited Number of Samples Collected at Autopsy." At the symposium, meetings with Russian scientists involved with the DRMIA resulted in a collaborative research agreement, sanctioned by the U. S. and Russian governments. The project, officially started in March, 1995 as a one-year feasibility study, is expected to greatly enhance understanding of plutonium biokinetics and dosimetry in man.

The primary focus of the first year of the joint Russian - U.S. collaboration focussed on comparison of the methods used by the DRMIA and the USTUR for collection and limited comparison of data. Communication with DRMIA scientists has been accomplished primarily by electronic mail and facsimile transmission. However, in August of 1995, three Russian scientists visited the USTUR facilities. During that visit, a project progress report comparing the methods and data of the two Registries was drafted and submitted to a peer-reviewed journal for publication. A number of differences in the Registries methods of operation were noted. Among them were:

1) The USTUR cases are derived from a number of work sites with differing operational, dosimetry, bioassay, and medical practices whereas, the DRMIA cases are from a single site and more likely homogeneous in terms of exposure histories and dosimetry;

2) Autopsies on DRMIA cases have been performed by a single group of pathologists, as compared with the USTUR which relies on pathologists available at the location and time of registrant death;

3) The USTUR has received and analyzed several whole-body donations which have provided more complete data regarding distribution of the actinide elements among body organs than that of the DRMIA;

4) Actinide levels in tissue samples collected by the DRMIA were generally higher than those of the USTUR;

5) Tissues collected by the DRMIA have all been analyzed on site by a single laboratory, while USTUR tissues have been analyzed by four separate laboratories, with intercomparisons available; 
6) Radiochemical analytical techniques differ between the two Registries; the DRMIIA utilized co-precipitation techniques and direct scintillation counting while the USTUR routinely uses radiotracers with alpha-spectrometry using state-of-the-art counting equipment.

Overall, there are more similarities than differences between the two Registries providing a number of advantages to be gained from the joint use of data. Some advantages are:

1) The USTUR and the DRMIA have post mortem data from more than 350 and 750 deceased registrants, respectively. Collaboration would increase the number of cases available for analysis by a factor of four relative to the number of USTUR deceased registrants thereby greatly enhancing the statistical power for variable data analysis.

2) Combining data sets will result in greater heterogeneity of the population studied. For example, the USTUR has very few female registrants while there were a large number of females in the Russian plutonium production work force.

3) A broader range of exposures and exposure situations will result from combination of data. The Russian workers had much higher occupational exposures to actinides as evidenced by a comparison of liver burdens in USTUR and DRMIA cases (Fig. 4). Median liver contents of plutonium in
DRMIA cases were 240 times those in USTUR cases and over $90 \%$ of DRMIA cases had higher liver concentrations than those of USTUR registrants.

4) The differences in body burdens of the Registries cases will allow an investigation of the dose-dependence or independence of biokinetic parameters. Body burdens in some of the Russian workers have been sufficiently such high such that some plutonium-related effects may be noted. In general, body burdens of U. S. workers were low enough that few effects could be conclusively ascribed to actinide exposures.

Frequency distributions of plutonium liver concentrations in USTUR and DRMIA cases are shown in Figure 4; both were log-normally distributed. The median liver concentration in the DRMIA cases was more than 200 times that of the USTUR cases. Since the liver is one of the major deposition sites of actinide elements, liver concentrations relate differences in the total body burdens or incorporation of actinide.

A proposal has been submitted to extend the collaborative project beyond the first-year feasibility study. This proposal contains many long-term objectives including a full investigation of actinide biokinetics in the human body as well as the relationship of body burdens at death to results of bioassays (urinalyses, fecal analyses, and in-vivo counts) made during life. 
Figure 4. Frequency distribution of plutonium liver concentrations in USTUR and DRMIA cases.

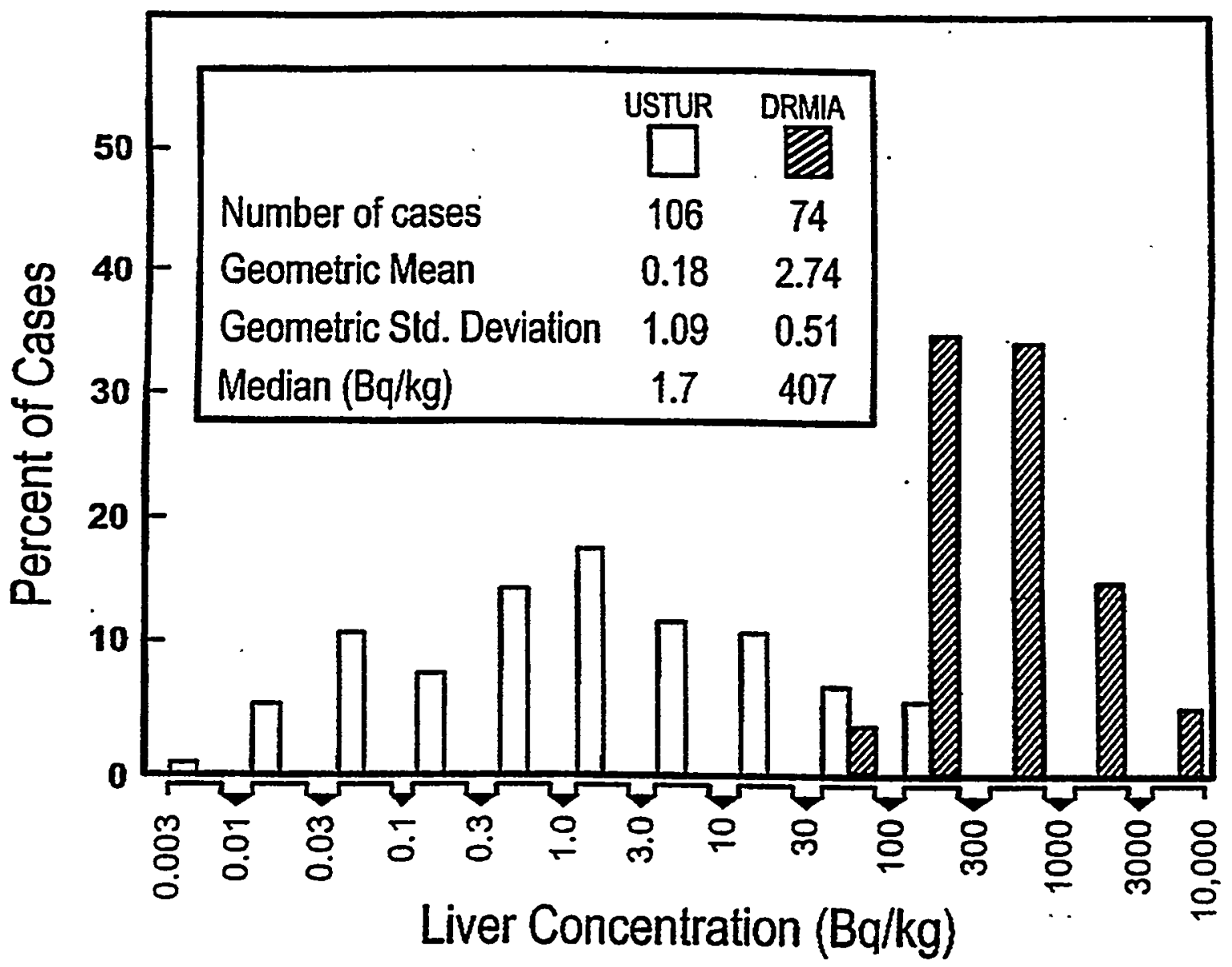




\section{ESTIMATION OF TOTAL ACTINIDE SKELETAL CONTENT FROM CONCENTRATIONS IN INDIVIDUAL BONE SAMPLES COLLECTED AT AUTOPSY}

Principal Faculty Investigator: Ronald E. Filipy

During routine autopsies (non wholebody donations), the USTUR collects bone samples which may include the sternum, one or more ribs, one or both clavicles, one or both patellae, and a vertebral wedge cut from within the abdominal cavity (Kathren 1989; 1995). These limited bone samples are the basis for estimation of the total skeletal content of plutonium and/or americium in these cases.

The USTUR has had a number of whole-body donations and, typically, onehalf the bones of each skeleton is radiochemically analyzed (McInroy et al. 1985). The remainder is used for other studies and for further radiochemical analysis if more data are required. Actinide activities of the analyzed portions of six of the wholebody skeletons (Kathren et al. 1994) were used to derive total skeletal activities for each case and are shown in Table 1 . Relationships of the measured actinide concentration in individual bones or bone groups to the average concentration in the entire skeletons of whole-body donors is a basis for estimation of skeletal content of routine autopsy cases if these ratios or relationships are found to be more or less constant from individual to individual.

The mean skeletal actinide concentration was calculated for each of the wholebody skeletons by dividing the sum of measured actinide contents in all the individual bone samples by the total weight of the samples. To determine the concen- tration ratios, actinide concentrations in individual bones or groups of bones of the same skeleton were divided by skeletal concentrations.

Both wet and ashed concentration ratios were calculated from each skeleton and the means of the six concentration ratios for each bone or bone group are shown in Table 2. The concentration ratios for ribs were based on average concentrations in ribs 5-10 of the whole-body skeletons; these ribs had similar concentrations of the actinide elements. Concentration ratios for the vertebral wedges were based on average concentrations in vertebral bodies from the fifth thoracic vertebra through the third lumbar vertebra. Again, concentrations in these bones were similar. These groups of bones were used rather than individual ribs or vertebral bodies because of the potential nonuniformity in sampling methods by pathologists performing routine autopsies. They were considered the most likely to be included in the samples collected.

For wet weight concentrations of ${ }^{241} \mathrm{Am}$, the patellar, clavicular, and rib concentration ratios provide the most precise estimate of skeletal concentration as indicated by the relatively small coefficients of variation (CV) for those ratios among the six whole body skeletons. The sternum and the vertebral wedge ratios have the greatest variation. For ashed weight concentrations of ${ }^{241} \mathrm{Am}$, the clavicle has 
the smallest CV with the sternum, again, the largest. The bone-to-skeleton concentration ratio for the ribs provided the most precise estimate of skeletal concentrations for both ${ }^{238} \mathrm{Pu}$ and ${ }^{239+240} \mathrm{Pu}$ whether based on wet weight or on ashed weight. The sternal and vertebral wedge plutonium concentration ratios were generally the most variable of the five bones evaluated. There are, however, no statistically significant $(<0.05)$ differences among the concentration ratios listed in Table 2 indicating that any of them would be equally useful for estimation of skeletal concentrations. The skeletal content can be estimated on the basis of each sample collected at an individual autopsy and the mean of those estimates reflects the total skeletal content.

There are advantages and some problems associated with the use of the concentration ratios for estimating total skeletal content of actinides from bone samples collected during routine autopsies. One primary advantage is that concentration ratios are independent of sample mass and thus essentially any sample size can be used, assuming the entire bone is sampled and analyzed to eliminate nonuniformity within an individual bone. Some of the problems include:

1. in a number of the early USTUR cases, it is not known whether the entire bone was sampled and analyzed;

2. there was occasional wide variation in analytical results for individual bone samples collected in the early years of the USTUR which can cause the skeletal estimates for those cases to have a high degree of uncertainty;
3. ashed bone weights were not measured for many of the early USTUR cases so wet concentration ratios rather than ashed ratios must be used for those cases and;

4. ashed fractions of bone samples (ashed weight divided by wet weights) were not consistent among the four laboratories that have analyzed USTUR samples in the past; therefore, the ashed concentration ratios are most useful if the autopsy samples were analyzed by the same laboratory that analyzed the wholebody skeletons.

The problems mentioned above notwithstanding, either the wet or ashed concentration ratios can be used to provide a reasonable estimate of the total skeletal activity in the majority of cases analyzed by the USTUR. These estimates can be used in conjunction with analytical data from other tissues and organs to provide a more reliable approximation of the total body burdens of actinides at death.

Acknowledgement: Data tables were compiled by USTUR graduate research assistant Charlene Hall.

\section{References}

Kathren, R. L. The United States Transuranium and Uranium Registries: Overview and recent progress. Rad. Protect. Dos. 26:323-330; (1989).

Kathren, R. L. The U. S. Transuranium and Uranium Registries. In: Young, J. P.; Yalow, R. S., eds. Radiation and public perception; advances in chem- 
istry 243. The American Chemical Society, Washington, DC. (1995).

Kathren, R. L.; Harwick, L. A., eds. Annual Report of the United States Transuranium and Uranium Registries. April 1992-September 1993.

Washington State University. USTUR0015-94 (1994).

Lynch, T.P.; Kathren, R.L.; McInroy, J.F. Macrodistribution of plutonium and americium in four human skeletons. J. Rad. Prot. 8:67-76 (1988).

McInroy, J. F.; Boyd, H. A.; Eutsler, B. C.; Romero, D. Preparation and analysis of the tissues and bones. Health Phys., Part IV: 49:587-621 (1985). 
Table 1. Summary of whole body skeletal actinide content. Unanalyzed portions of the skeleton were estimated based on ratios to the analyzed portion. Teeth, cartilage, and finger and toenails were not included in the skeleton.

\begin{tabular}{|c|c|c|c|c|c|c|}
\hline Case & $0102^{a}$ & 0193 & 0208 & 0212 & 0213 & 0242 \\
\hline Wet Weight (grams) & 8990.0 & 8450.0 & 8000.0 & 10400.0 & 8740.0 & 9670.0 \\
\hline Ash Weight (grams) & 2540.0 & 2720.0 & 2630.0 & 3230.0 & 2880.0 & 3090.0 \\
\hline \multicolumn{7}{|l|}{ Skeletal } \\
\hline Ash Fraction & 0.28 & 0.32 & 0.33 & 0.31 & 0.33 & 0.32 \\
\hline \multicolumn{7}{|l|}{ Am-241 } \\
\hline Activity Bq (SD) & 4440.0 & 5.38 & 3.37 & 39.0 & 12.4 & 31.8 \\
\hline \multicolumn{7}{|l|}{ Mean Skeletal Conc. } \\
\hline $\mathrm{Bq} / \mathrm{kg}$ Wet Wt. (SD) & 494.0 & 0.64 & 0.42 & 3.76 & 1.42 & 3.29 \\
\hline Bq/kg Ash Wt. (SD) & 1750.0 & 1.98 & 1.28 & 12.1 & 4.30 & 10.3 \\
\hline Pu-238 & NA & & & & & \\
\hline \multicolumn{7}{|l|}{ Total Skeletal } \\
\hline Activity Bq (SD) & & 0.85 & 0.55 & 2.10 & 16.40 & 3.34 \\
\hline \multicolumn{7}{|l|}{ Mean Skeletal Conc. } \\
\hline Bq/kg Wet Wt. (SD) & & 0.10 & 0.07 & 0.20 & 1.88 & 0.35 \\
\hline $\mathrm{Bq} / \mathrm{kg}$ Ash Wt. (SD) & & 0.31 & 0.21 & 0.65 & 5.69 & 1.08 \\
\hline Pu-239+240 & NA & & & & & \\
\hline \multicolumn{7}{|l|}{ Total Skeletal } \\
\hline Activity Bq (SD) & & 49.2 & 87.2 & 113.0 & 177.0 & 408.0 \\
\hline \multicolumn{7}{|l|}{ Mean Skeletal Conc. } \\
\hline Bq/kg Wet Wt. (SD) & & 5.83 & 10.9 & 10.9 & 20.2 & 42.2 \\
\hline Bq/kg Ash Wt. (SD) & & 18.1 & 33.2 & 35.0 & 61.4 & 132.0 \\
\hline
\end{tabular}

Mean Skeletal Ash Fraction for all six cases 0.32

${ }^{a}$ Per Lynch, et al. (1988) 


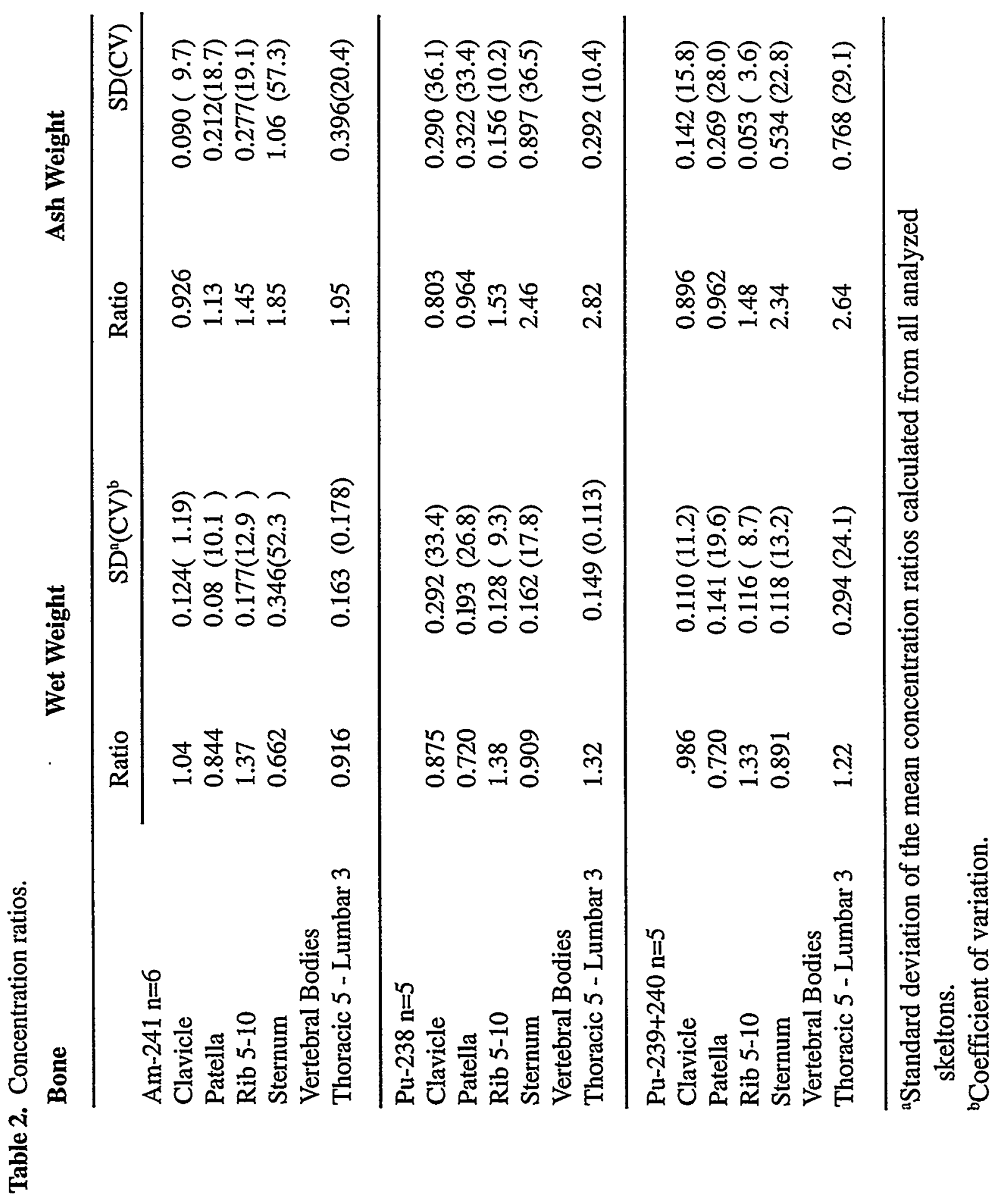




\section{TEETH AS AN INDICATOR OF TOTAL SKELETAL ACTINIDE}

\section{Principal Faculty Investigator: Ronald L. Kathren}

Accurate estimation of the total skeletal content of actinide from one or a limited number of samples has long been a goal of the Registries. If an appropriate technique could be developed to provide such estimates with a reasonable degree of reliability, the program of the Registries would be greatly facilitated both from the standpoint of time required to obtain a measurement of skeletal activity and cost.

A number of years ago, Lovaas and Hursh (1968) suggested that the content of ${ }^{226} \mathrm{Ra}$ and ${ }^{210} \mathrm{~Pb}$ in teeth could be used to estimate the total quantity of these elements in the skeleton as a whole. For ${ }^{226} \mathrm{Ra}$ they found that the mean concentration in teeth, when compared with that in various bones (mandible, calvarium, tibia shaft, femur head, and rib) would lie within $\pm 50 \%$ of the average bone concentration at the $95 \%$ confidence level. For ${ }^{210} \mathrm{~Pb}$, variability was greater and dependent upon the level in the specific bone to which the tooth concentration was compared. If this same relationship held true for the actinides, teeth could be used as a surrogate for the total skeletal deposition of actinides. This brief study was carried out to determine if either the concentration or total quantity of an actinide element in the teeth could be correlated with the total skeletal content of that same actinide.

Post mortem measurements of the actinide content in teeth and bones from whole body donors to the Registries were used for this assessment. For whole body donors, the general practice is to radiochemically determine the actinide activity in the bones from the right half of the skeleton, and to extrapolate this measurement of a half skeleton to the full skeletal content as has been previously described by McInroy and his coworkers in 1985. The basic multistep radiochemical procedure calls for dry and wet ashing, followed by dissolution in acid and ion exchange separation, electrodeposition onto a suitable planchet, and final assay by quantitative alpha spectrometry (McInroy et al. 1985; McInroy, Gonzales, and Miglio 1992).

Results of the radiochemical analyses of the various bones or bone pieces and teeth are given in Table 3 along with a calculated Activity Fraction (AF) for each tooth. The AF is defined as the activity in a tooth relative to that in the total skeleton, or, in other words, the fraction of the activity in skeleton as a whole that is found in the tooth. Concentration Ratios (CR) were established by comparing the concentration of the nuclide in each tooth with the mean skeletal concentration. The variance of the measured $C R$ values was determined using simplified rules for compounding errors as reported by Brodsky in 1982. In general, the CR was reasonably consistent among the several teeth obtained for any individual case, although the variation from case to case was marked.

No correlation was found between total actinide in the skeleton and the activity in the teeth, or between the average skeletal concentration and the concentration in the teeth. This finding indicates that teeth do not provide a reliable means 
of determining the total skeletal content or average concentration of plutonium or americium and thus cannot be used as a surrogate for the skeletal burden of actinide.

The above finding is not surprising in view of the physiology of the teeth and bone. Unlike radium and lead, which as calcium analogues deposit throughout the bone matrix (i.e. are volume seekers), the actinide elements, specifically plutonium and americium, are bone surface seekers and are deposited onto both the periosteal and the endosteal surfaces of the bone. Bone resorption or turnover occurs continuously, and at a rate that is determined by a number of factors including age, hormonal balance, diet and exercise, so that in time, some of the actinide deposition is covered by a layer of new bone with some actinide released and later redeposited on the new bone surface (Toohey, 1994). However, teeth do not remodel as bone does, and although attrition occurs with aging of the tooth, the enamel is not replaced. The enamel, covering the top of the tooth, is completely established by eight years of age in all teeth except the third molar, in which the enamel is completed by age sixteen.

Cementum is similar to bone, chemically and physiologically. The blood supply to the tooth is only within the pulp and the periodontium, which includes the cementum. With age, the cementum is covered over with new cementum, comparable to the activity of resorption and recycling of bone, but the old cementum is only covered over and is not reabsorbed, a mechanism similar to, yet different from the surface deposition of actinides which are apparently recycled or released to the transfer compartment (blood) at least in part, albeit with a long residence half-time. There are blood vessels within regions between the roots of those teeth with multiroots, the molars and premolars.

There is no blood supply to the enamel in any teeth and thus only the inner surface of the tooth and the outer portion of the root come into contact with blood that would be carrying actinides following an intake (Oser 1965; Sicher and DuBrul 1975). Hence, actinide deposition could only occur through the root canal and the pulp to the cementum and dentin layers of the tooth.

Acknowledgement: Data tables were compiled by USTUR graduate research assistant Mickey M. Hunacek.

\section{References}

Brodsky, A., Ed. Statistical methods of data analysis. In: CRC Handbook of Radiation Measurements and Protection. Section A. Vol. II, Biological and mathematical information. Boca Raton, FL: CRCPress (1982) pp. 261330.

Lovaas, A. I. and J.B. Hursh. Radium-226 and $\mathrm{Pb}-210$ in human teeth and bones. Health Phys. 14:549-55 (1968).

Kathren, R.L., L. A. Harwick, R. E. Toohey, J.J. Russell, R.E. Filipy, S.E. Dietert, M.M. Hunacek, and C.A. Hall. The United States Transuranium and Uranium Registries. Report of the period October 1, 1992-September 30,1993. Washington State University. USTUR-0015-95 (1994). 
McInroy, J. F., H.A. Boyd, B.C. Eutsler and D. Romero. Preparation and analysis of the tissues and bones. Part IV; Health Phys. 49:587-621 (1985).

McInroy, J. F., Gonzales, E. R. and J.J. Miglio. Measurement of thorium isotopes and ${ }^{228} \mathrm{Ra}$ in soft tissues and bones of a deceased Thorotrast patient. Health Phys. 63:54-71 (1992).

McInroy, J. F., R.L. Kathren, R. L., and M.J. Swint. Distribution of plutonium and americium in whole bodies donated to the United States Transuranium Registry. Rad. Prot. Dos. 26: 151-158 (1989).

Oser, B.L. Hawk's Physiological Chemistry. Fourteenth Ed. NY: McGrawHill Book Co. (1965).

Sicher, H. and E.L. DuBrul. Oral Anatomy. St. Louis: C.V. Mosby Co. (1975).

Toohey, R. E. "Biokinetics of bone-seeking radionuclides" In: Internal Radiation Dosimetry. Raabe, O.G., ed. Health Physics Summer School, Madison, WI: Medical Physics Publishing (1994) pp.197-216. 
Table 3. Fraction of Skeletal Activity in Teeth

\begin{tabular}{|c|c|c|c|c|c|c|c|c|c|c|}
\hline $\begin{array}{l}\text { USTUR } \\
\text { case \# }\end{array}$ & & $\begin{array}{l}\text { Wet wt } \\
\text { Tooth" } \\
\text { (g) }\end{array}$ & $\begin{array}{c}\text { Aclivity" } \\
\text { (mBq) }\end{array}$ & $\begin{array}{l}\text { Activityc } \\
\text { Fractlon } \\
(\times 1000)\end{array}$ & $\begin{array}{c}\text { Cone Wet" } \\
\text { Bq kg-1 }\end{array}$ & SD Wet & $\begin{array}{c}\text { Conc } \\
\text { Ash }^{\mathrm{A}} \\
\text { Bq kg-1 }\end{array}$ & $\begin{array}{l}\text { SD } \\
\text { Ash" }\end{array}$ & $\begin{array}{l}\text { Conc }^{6} \\
\text { Rntio } \\
\text { Wet }\end{array}$ & $\begin{array}{l}\text { Conc }^{b} \\
\text { Ratio } \\
\text { Ash }\end{array}$ \\
\hline \multirow[t]{16}{*}{$0102 \mathrm{Am}$} & Total Skcleton & & $4.440,000$ & 1,000 & & & & & & \\
\hline & Mean Skeleton & & & & 494 & 4 & 1749 & 13 & & \\
\hline & Canine L & 1.5 & 760 & .17 & 505 & 27 & 702 & 38 & 1.02 & 0.40 \\
\hline & Canine U & 1.8 & 900 & .20 & 497 & 21 & 673 & 29 & 1.01 & 0.38 \\
\hline & Incisor L1 & 0.5 & 330 & .074 & 662 & 52 & 788 & 62 & 1.34 & 0.45 \\
\hline & Incisor L2. & 0.7 & 450 & .10 & 641 & 40 & 916 & 57 & 1.30 & 0.52 \\
\hline & Incisor U1 & 1.2 & 620 & .14 & 513 & 24 & 699 & 32 & 1.04 & 0.40 \\
\hline & Incisor U2 & 0.8 & 430 & .10 & 542 & 25 & 734 & 34 & 1.10 & 0.42 \\
\hline & Molar L7 & 2.3 & 1020 & .23 & 442 & 24 & 620 & 34 & 0.89 & 0.35 \\
\hline & Molar L8 & 1.9 & 1010 & .23 & 533 & 33 & 751 & 47 & 1.08 & 0.43 \\
\hline & Molar U7 & 2.4 & 1410 & .32 & 588 & 30 & 810 & 41 & 1.19 & 0.46 \\
\hline & Molar U8 & 1.9 & 1290 & .27 & 642 & 37 & 880 & 51 & 1.30 & 0.50 \\
\hline & Premolar LA & 1.1 & 690 & .16 & 626 & 45 & 861 & 62 & 1.27 & 0.49 \\
\hline & Premolar L5 & 1.1 & 740 & .17 & 704 & 46 & 968 & 63 & 1.43 & 0.55 \\
\hline & Premolar U4 & 1.1 & 650 & .15 & 595 & 28 & 838 & 40 & 1.20 & 0.48 \\
\hline & Premolar U5 & 1.1 & 610 & .14 & 554 & 25 & 743 & 33 & 1.12 & 0.42 \\
\hline Total & & 19.4 & 10,910 & & & & & & & \\
\hline Means & & 1.4 & & .18 & 575 & & 785 & & 1.16 & 0.45 \\
\hline SD & & 0.6 & & .066 & 74 & & 99 & & 0.15 & 0.06 \\
\hline
\end{tabular}


Table 3. Fraction of Skeletal Activity in Teeth (continued)

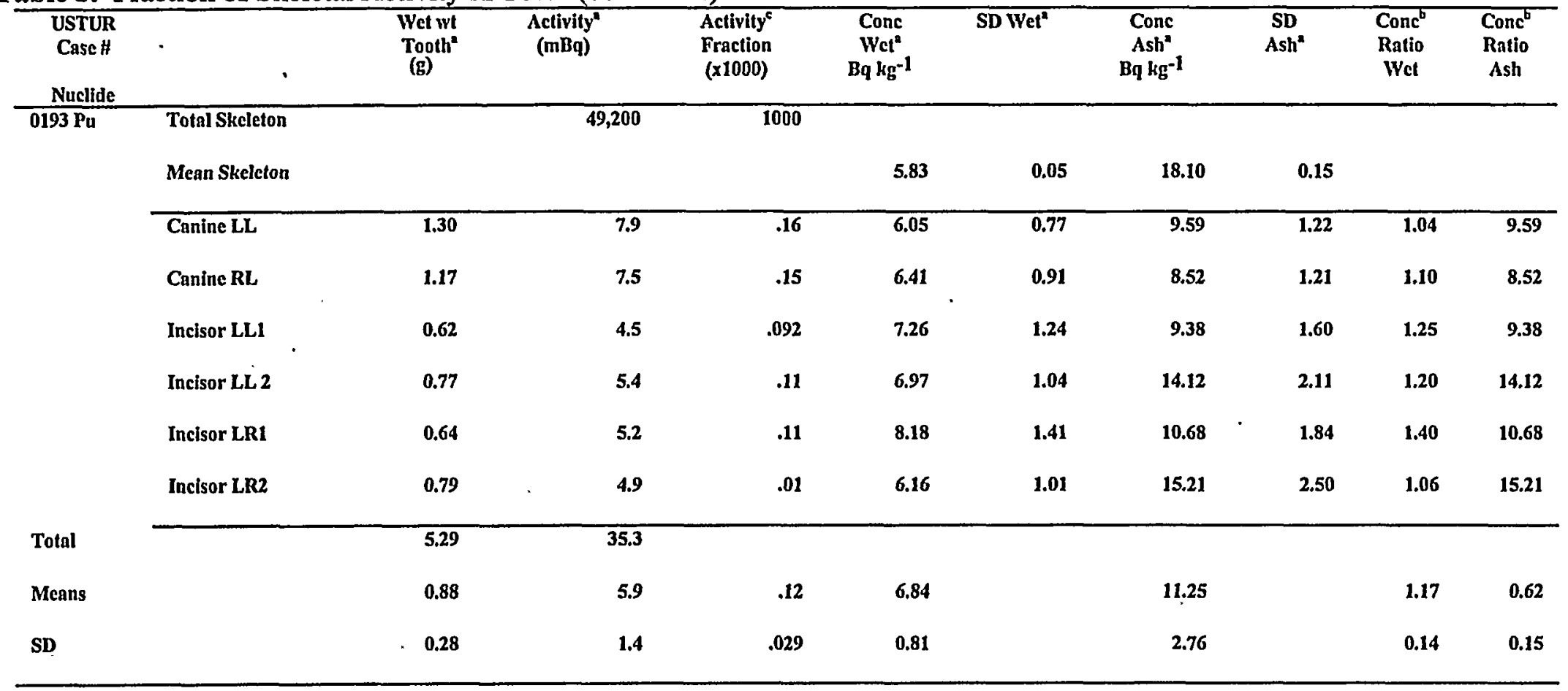


Table 3. Fraction of Skeletal Activity in Teeth (continued)

\begin{tabular}{|c|c|c|c|c|c|c|c|c|c|c|}
\hline $\begin{array}{l}\text { USTUR } \\
\text { Case \# } \\
\text { Nuclide }\end{array}$ & & $\begin{array}{l}\text { Wet wt } \\
\text { Tootha } \\
\text { (g) }\end{array}$ & $\begin{array}{c}\text { Activity } \\
\text { (mBq) }\end{array}$ & $\begin{array}{c}\text { Activity } \\
\text { Fraction } \\
\text { (x1000) }\end{array}$ & $\begin{array}{c}\text { Conc } \\
\text { WET }^{*} \\
\text { Bq kg-1 }\end{array}$ & $\begin{array}{c}\text { SD } \\
\text { Wet }^{*}\end{array}$ & $\begin{array}{c}\text { Conc } \\
\text { ASII } \\
\text { Bq kg-1 }\end{array}$ & $\begin{array}{l}\text { SD' } \\
\text { Ash" }\end{array}$ & $\begin{array}{l}\text { Conc }^{6} \\
\text { Ratio } \\
\text { Wet }\end{array}$ & $\begin{array}{l}\text { Conc } \\
\text { Ratio } \\
\text { Ash }\end{array}$ \\
\hline \multirow{15}{*}{$\begin{array}{c}\text { Nuclide } \\
\mathbf{0 2 0 8} \\
\mathbf{P u}\end{array}$} & Total Skeleton & & 87,200 & 1000 & & & & & & \\
\hline & Mean Skeleton ${ }^{b}$ & & & & 10.9 & 0.05 & 33.16 & 0.16 & & . \\
\hline & Canine RL & 1.28 & 11.6 & .13 & 9.05 & 0.67 & 9.00 & 0.68 & 0.83 & 0.27 \\
\hline & Canine RU & 1.26 & 8.5 & .097 & 6.78 & 0.59 & 8.21 & 0.71 & 0.62 & 0.25 \\
\hline & Incisor LR2 & 0.63 & 5.4 & .062 & 8.6 & 0.87 & 10.83 & 1.10 & 0.79 & 0.33 \\
\hline & Incisor URI & 2.41 & 3.7 & .042 & 1.54 & 1.58 & 7.43 & 7.63 & 0.14 & 0.22 \\
\hline & Incisor UR2 & 0.78 & 4.6 & .053 & 5.85 & 0.68 & 8.30 & 0.96 & 0.54 & 0.25 \\
\hline & Molar RL 6 & 2.83 & 13.1 & .15 & 4.61 & 0.42 & 14.50 & 1.31 & 0.42 & 0.44 \\
\hline & Molar RL7 & 1.54 & 14.4 & .17 & 9.35 & 0.61 & 14.54 & 0.95 & 0.86 & 0.44 \\
\hline & Molar RU6 & 2.45 & 16.3 & .19 & 6.67 & 0.42 & 11.75 & 0.74 & 0.61 & 0.35 \\
\hline & Molar RU7 & 5.07 & 17.4 & .20 & 3.42 & 0.20 & 9.49 & 0.55 & 0.31 & 0.29 \\
\hline & Premolar LA & 0.93 & 9.0 & .10 & 9.69 & 0.81 & 11.55 & 0.96 & 0.89 & 0.35 \\
\hline & Premolar L5 & 0.65 & 7.3 & .084 & 11.27 & 1.12 & 15.26 & 1.52 & 1.03 & 0.46 \\
\hline & Premolar U4 & 1.28 & 7.1 & .081 & 5.51 & 0.49 & 8.02 & 0.72 & 0.51 & 0.24 \\
\hline & Premolar U5 & 0.89 & 7.7 & .088 & 8.62 & 0.75 & 11.62 & 1.02 & 0.79 & 0.35 \\
\hline Total & & 22.00 & 12.6 & & & & & & & \\
\hline Means & & 1.69 & 9.7 & .11 & 7.00 & & 10.82 & & 0.64 & 0.33 \\
\hline SD & & 1.25 & 4.5 & .052 & 2.78 & & 2.68 & & 0.25 & 0.08 \\
\hline
\end{tabular}


Table 3. Fraction of Skeletal Activity in Teeth (continued)

\begin{tabular}{|c|c|c|c|c|c|c|c|c|c|c|}
\hline $\begin{array}{c}\text { USTUR } \\
\text { Case \# } \\
\text { Nuclide } \\
\end{array}$ & $\cdot$ & $\begin{array}{l}\text { Wet wt" } \\
\text { Tooth } \\
\text { (g) }\end{array}$ & $\begin{array}{l}\text { Activity" } \\
\text { (mBq) }\end{array}$ & $\begin{array}{c}\text { Activity } \\
\text { Fraction } \\
\text { (x1000) }\end{array}$ & $\begin{array}{c}\text { Conc } \\
\text { WETT" } \\
\text { Bq kg-1 }\end{array}$ & SDWet ${ }^{2}$ & $\begin{array}{c}\text { Conc } \\
\mathrm{ASH}^{2} \\
\mathrm{~Bq} \mathrm{~kg}^{-1}\end{array}$ & $\begin{array}{l}\text { SD } \\
\text { Ash" }^{2}\end{array}$ & $\begin{array}{l}\text { Conc }^{b} \\
\text { Ratio } \\
\text { Wet }\end{array}$ & $\begin{array}{l}\text { Conc } \\
\text { Ratio } \\
\text { Ash }\end{array}$ \\
\hline \multirow{7}{*}{$\begin{array}{l}0213 \\
\text { Pu-239 }\end{array}$} & Total Skeleton & & 177,000 & 1,000 & & & & & & \\
\hline & Mean Skeleton & $\cdot$ & & & 20.21 & 0.1 & 61.35 & 0.30 & & \\
\hline & Canine RL & 1.15 & 6.6 & .037 & 5.71 & 0.55 & 8.00 & 0.77 & 0.28 & 0.13 \\
\hline & Incisor LRI & 0.62 & 8.6 & .048 & 13.83 & 1.08 & 19.94 & 1.55 & 0.68 & 0.33 \\
\hline & Incisor LR2 & 0.72 & 11.9 & .067 & 16.49 & 1.16 & 22.84 & 1.60 & 0.82 & 0.37 \\
\hline & Incisor RU2 & 0.75 & 14.1 & .080 & 18.87 & 1.24 & 28.30 & 1.87 & 0.93 & 0.46 \\
\hline & Premolar L & 0.92 & 21.6 & .12 & 23.46 & 1.30 & 86.32 & 4.80 & 1.16 & 1.41 \\
\hline Total & & 4.16 & 62.8 & & & & & & & \\
\hline Mcan & & 0.83 & 12.6 & .071 & 15.67 & & 33.08 & & 0.78 & 0.54 \\
\hline SD & & 0.21 & 5.8 & .033 & 6.60 & & 30.67 & & 0.33 & 0.50 \\
\hline $\begin{array}{l}0212 \\
\text { Pu-239 }\end{array}$ & $\begin{array}{l}\text { Total skeleton } \\
\text { Mean Skelcton }\end{array}$ & & 113,100 & 1,000 & 10.92 & 0.06 & 35.04 & 0.18 & & \\
\hline $\begin{array}{l}\text { Overall Pu } \\
\text { \& Am Mean }\end{array}$ & & & & 3.12 & & & & & 0.94 & 0.45 \\
\hline SD & & & & 5.10 & & & & & 0.27 & 0.21 \\
\hline
\end{tabular}


Table 3. Fraction of Skeletal Activity in Teeth (continued)

\begin{tabular}{|c|c|c|c|c|c|c|c|c|c|c|}
\hline $\begin{array}{l}\text { USTUR } \\
\text { Case \# } \\
\text { Nuclide }\end{array}$ & . & $\begin{array}{l}\text { Wet wt } \\
\text { Tooth } \\
\text { (g) }\end{array}$ & $\begin{array}{c}\text { Activity } \\
\text { (mBq) }\end{array}$ & $\begin{array}{r}\text { Aclivity } \\
\text { Fraction }^{c} \\
(x 1000)\end{array}$ & $\begin{array}{c}\text { Conc } \\
\text { WET } \\
\text { Bq kg-1 }\end{array}$ & SDWet" & $\begin{array}{c}\text { Conc } \\
\text { ASII" } \\
\text { Bq kg-1 }\end{array}$ & $\begin{array}{c}\mathrm{SD} \\
\Lambda \operatorname{sh}^{2}\end{array}$ & $\begin{array}{l}\text { Conc } \\
\text { Rntio } \\
\text { Wet }\end{array}$ & $\begin{array}{l}\text { Conc }^{6} \\
\text { Ratio } \\
\text { Ash }\end{array}$ \\
\hline & Canine RL & 0.82 & 10.0 & 0.88 & 7.84 & 0.78 & 10.36 & 1.03 & 0.72 & 0.30 \\
\hline $\begin{array}{l}1001 \\
\text { Th.232 }\end{array}$ & $\begin{array}{l}\text { Total Skeleton } \\
\text { Mean Skeleton }\end{array}$ & & $\begin{array}{l}0.67 \\
1595\end{array}$ & $\begin{array}{c}1000 \\
584\end{array}$ & $4353^{c}$ & 1579 & & & & \\
\hline & Canine RL & 0.61 & 8.1 & 0.072 & 13.21 & 1.88 & 26.86 & $\overline{3.82}$ & .0083 & .0062 \\
\hline & Canine RU & 1.54 & 21.7 & 0.19 & 14.09 & 1.32 & 21.70 & 2.03 & .0088 & .0050 \\
\hline & Incisor LR 1 & 0.81 & 13.2 & 0.12 & 16.35 & 2.98 & 22.07 & 4.02 & .0101 & .0051 \\
\hline & Incisor LR 2 & 1.21 & 23.6 & 0.21 & 19.50 & 2.91 & 29.49 & 4.40 & .0122 & .0068 \\
\hline & Molar L6 R & 1.04 & 14.3 & 0.13 & 13.77 & 2.77 & 20.46 & 4.11 & .0086 & .0047 \\
\hline & Molar L7 R & 1.55 & 36.2 & 0.32 & 23.37 & 1.88 & 32.93 & 2.65 & .0147 & .0076 \\
\hline & Molar U6 R & 4.48 & 52.5 & 0.46 & 11.71 & 0.85 & 17.49 & 1.27 & .0073 & .0040 \\
\hline & Molar U7 R & 2.14 & 43.2 & 0.38 & 20.19 & 1.93 & 30.86 & 2.95 & .0127 & .0071 \\
\hline & Premolar L5 & 1.71 & 38.4 & 0.34 & 22.43 & 2.24 & $\mathbf{3 4 . 8 7}$ & 3.48 & .0141 & .0080 \\
\hline & Premolar U5 & 2.67 & 19.2 & 0.17 & 7.20 & 1.23 & 8.36 & 1.43 & .0045 & .0019 \\
\hline Mean & & 1.78 & & & & & & & .0101 & .0056 \\
\hline SD & & 1.13 & & & & & & & .0032 & .0019 \\
\hline
\end{tabular}

: Kathren et al. 1993

of conceletal concentration

Fraction of total skeletal activity in tooth

Table 4. Ash Concentration Ratio for specific tooth types

\begin{tabular}{lccc}
\hline Tooth & Number & & $\begin{array}{c}\text { Mean Ash } \\
\text { Concentration Ratio }\end{array}$ \\
\hline Canine & 7 & 0.35 & SD \\
Incisor & 14 & 0.46 & 0.14 \\
Molar & 8 & 0.41 & 0.18 \\
Premolar & 9 & 0.53 & 0.07 \\
& & & 0.34 \\
\hline
\end{tabular}




\section{POSTMORTEM DISTRIBUTION OF ${ }^{238}$ PU IN A WHOLE BODY DONOR 18 YEARS AFTER ACUTE INHALATION EXPOSURE}

\section{Principal Faculty Investigator: Ronald L. Kathren}

USTUR Case 0259 was a caucasian male whole body donor who died at age 54 from arteriosclerotic heart disease. Other findings at autopsy included gall stones and simple cyst of the liver and kidney. There was no evidence of malignancy, and his medical history during life had been unremarkable. From June 1957 until his death in June 1989, USTUR 0259 was employed as a metallurgist with potential for chronic low level exposure to ${ }^{238} \mathrm{Pu}$. There was no indication of measurable intake of this nuclide until July 1971 , some eighteen years prior to his death, when suffered an acute inhalation exposure to high fired ${ }^{238} \mathrm{PuO}_{2}$ in a ceramic matrix. Subsequent to the accident, particle size AMAD was estimated as $4.4 \mu \mathrm{m}$ (Guilmette, et al. 1994).

Nasal wipes taken immediately after the accident were positive for ${ }^{238} \mathrm{Pu}$ verifying the acute inhalation exposure. A single fecal sample was collected two days postexposure and found to contain no detectable ${ }^{238} \mathrm{Pu}$ activity $\left(\mathrm{L}_{\mathrm{c}}=20 \mathrm{~Bq}\right)$. In vivo chest counts taken 12 days postexposure likewise failed to detect ${ }^{238} \mathrm{Pu}\left(\mathrm{L}_{\mathrm{c}}\right.$ stated as $110 \mathrm{~Bq})$. Initially, ${ }^{238} \mathrm{Pu}$ was not detectable in urine $\left(\mathrm{L}_{\mathrm{c}} \approx 1 \mathrm{mBq}\right)$, but within days, activity was observed in the urine and found to steadily increase with a doubling time of approximately 250 days (Figure 5).

${ }^{238} \mathrm{Pu}$ excretion in the urine peaked at about $15 \mathrm{mBq}$ about 5 years postexposure, then dropped slightly to what appeared to be a more or less constant daily output of about $10 \mathrm{mBq}$ until the time of his death 18 years postexposure. As shown in Figure 5, the urinary excretion of ${ }^{238} \mathrm{Pu}$ could be fit to a curve consistent with the models put forth in ICRP Publications 66 and 67. (ICRP 24, 1994, and ICRP 20(2), 1989)

After death, this whole body donation to the Registries was handled in accordance with the standard protocols in effect at the time (Breitenstein 1981; Kathren 1989). An autopsy was performed by an independent pathologist and the body sent for radiochemical analysis to LANL. The basic radioanalytical procedures used have been described in detail (Boyd, et al. 1981; McInroy, et al. 1985).

Results of radiochemical analysis of tissues of the whole body are summarized in Table 5. About half of the ${ }^{238} \mathrm{Pu}$ in the body was found in liver, with 37 per cent in the skeleton. Only 10 per cent of total body burden of ${ }^{238} \mathrm{Pu}$ was found in the respiratory tract. Assuming the route of entry to be inhalation, the systemic distribution indicated 53 per cent in the liver, 41 per cent in the skeleton, and about 3 per cent in the muscle, as compared with average values of 35,54 , and 6.5 per cent respectively in these tissues for ${ }^{239+240} \mathrm{Pu}$ in five previous whole body donors to the Registries (McInroy, Kathren, and Swint 1989; Kathren, et al. 1994)

Considering individual variability 
and the differences in exposure and time after exposure among the five ${ }^{239+240} \mathrm{Pu}$ cases and USTUR 0259, it is impossible to state with any degree of confidence that the differences in the relative distribution between skeleton and liver of the Pu isotopes are significant, although they might be interpreted as suggestive of this possibility.

However, the USTUR 0259 results may also be compared to a previous study of the relative activity of $\mathrm{Pu}$ in skeleton and liver of persons with largely chronic low level exposure to $\mathrm{Pu}$ at several years to decades postexposure. In this study, Kathren and his coworkers (1987) found that in 36 cases for which data were available, 63.4 per cent of the total ${ }^{238} \mathrm{Pu}$ resident in both the skeleton and liver at the time of death was in the skeleton, as compared with 53.2 per cent ${ }^{239+240} \mathrm{Pu}(43$ cases). This difference was significant at the 95 per cent confidence level. However, in 11 of the 36 cases examined for ${ }^{238} \mathrm{Pu}$, less than half of the total of this isotope in the skeleton and liver was in the skeleton, and in one case the fraction in the skeleton was as low as 20 per cent. For USTUR 0259, the comparable percentage is 43 , well within the range and not quite one standard deviation below the mean percentage of the 36 observed in Case 0259. This not appreciably different from, and indeed was entirely consistent with the models put forth by ICRP $(1979 ; 1986)$ and those developed by the USTUR (Kathren 1989, 1994) for plutonium.

A more detailed distribution of the activity in the various components of the respiratory tract is shown in Table 6. The distribution between lung and lymph nodes compares favorably with what has been previously observed in USTUR cases (Kathren, et al. 1993). In USTUR 0259, approximately 70 per cent of the total ${ }^{238} \mathrm{Pu}$ in the respiratory tract was found in the lungs. The concentration of ${ }^{238} \mathrm{Pu}$ in the lung tissue was $16 \mathrm{mBq} / \mathrm{g}$ as compared with a weighted mean concentration of 1.3 $\mathrm{Bq} / \mathrm{g}$ for the associated lymph nodes, giving a ratio of concentration in the lymph nodes to that in the lungs of 81 , somewhat greater than the geometric mean value of value $13 \pm 5.8$ reported for 29 cases, but well within the range of values $(0.046$ 261) reported for all cases.

The urinary excretion data shown in Figure 5 provides striking evidence of a biokinetic difference between inhaled particulates of ${ }^{238} \mathrm{Pu}$ and ${ }^{239+240} \mathrm{Pu}$. As has been shown recently by Guilmette, et al. (1994) on the basis of in vivo measurements, urinary excretion of ${ }^{238} \mathrm{Pu}$ in humans acutely exposed to ceramic ${ }^{238} \mathrm{PuO}_{2}$ particles is consistent with studies with experimental animals which show a progressive increase in the urinary excretion rate over the first few years post exposure. This has been explained as a result of the continuous fragmentation of the initially insoluble ${ }^{238} \mathrm{PuO}_{2}$ particles after deposition in the lung caused by their high specific activity relative to that of ${ }^{239+240} \mathrm{Pu}$. This process does not occur with insoluble particulates the lower specific activity ${ }^{239+240} \mathrm{Pu}$, and likely does not occur in most cases of occupational inhalation exposure to ${ }^{239+240} \mathrm{Pu}$ even though some ${ }^{238} \mathrm{Pu}$ is present in the isotopic mix.

\section{Discussion}

It is well known that plutonium is rapidly bound to plasma proteins which 
help inhibit the formation of large and rapidly phagocytized plutonium aggregates and is most likely responsible for the slow initial appearance of $\mathrm{Pu}$ in the urine. Plutonium has also been shown to complex with the iron-transport protein transferrin which is subsequently converted to ferritin and stored in such RES tissues as: liver, spleen, lymph nodes, and bone marrow.

The failure to detect ${ }^{238} \mathrm{Pu}$ activity in the fecal sample taken only 2 days postexposure is a reflection of the high insolubility of the high fired ${ }^{238} \mathrm{PuO}_{2}$ particles which were retained initially in the respiratory tract. As the particles began to disintegrate due to particle recoil and possibly enzyme action, the smaller plutoniumprotein complexes formed are translocated via the blood to other tissues i.e., lung lymph nodes, liver, spleen, an skeleton. The small quantity of ${ }^{238} \mathrm{Pu}$ detected in the fecal sample of one of the other individuals involved in the same accident was most likely from particles passing from the mouth or nose down to the stomach via ciliary action.

\section{References}

Boyd, H. A., Eutsler, B.C. and McInroy, J.F. Determination of americium and plutonium in autopsy tissue: Methods and Problems. In: Actinides In Man and Animals, M.E. Wrenn, Ed. Salt Lake City: RD Press pp. 43-52 (1981).

Breitenstein, B.D., Jr. The United States Transuranium Registry. In: Actinides in man and animals. M.E. Wrenn, Ed.

Salt Lake City: RD Press pp. 269-272 (1981).

Guilmette, R.A., Griffith, W.C., Hickman,
A. W. Intake assessment for workers that inhaled ${ }^{238} \mathrm{Pu}$ Aerosols. Rad. Prot. Dos. 53:127-132 (1994).

International Commission on Radiological Protection (ICRP), Human respiratory tract model for radiological protection. ICRP Publication 66, Ann. ICRP 24 (1-3):1 (1994).

International Commission on Radiological Protection, Age-dependent doses to members of the public from intake of radionuclides: Part 1 , ICRP Publication 56, Ann. ICRP 20(2):1 (1989).

International Commission on Radiological Protection. Age-dependent doses to members of the public from intake of radionuclides. Oxford: Pergamon Press; ICRP Publication 67, Part 2; Ann. ICRP 23(3/4):1 (1993).

International Commission on Radiological Protection. Limits for intakes of radionuclides by workers. Oxford: Pergamon Press; ICRP Publication 30, Ann. ICRP 2(2/4):1-116 (1979).

International Commission on Radiologi cal Protection (ICRP). The metabolism of plutonium and related elements. Ann. ICRP 16(2/3):1-98 (1986).

Kathren, R.L. Towards improved biokinetic models for actinides. Rad. Prot. Dos. 53:219-2277 (1994).

Kathren, R.L., McInroy, J.F., Pixley, M.M., and Swint, M.J. Partitioning ratio of 
${ }^{238} \mathrm{Pu},{ }^{239} \mathrm{Pu}$ and ${ }^{241} \mathrm{Am}$ in liver and skelton of US Transuranium Registry autopsy cases. Health Phys. 54(2):181-188 (1987).

Kathren, R.L., et al. The United States Transuranium and Uranium Registries. Report of the period October 1, 1992 - September 30,1993. Washington State University. USTUR-001595 (1994).

McInroy, J.F., Kathren, R.L. and Swint, M.J. Distribution of plutonium and americium in whole bodies donated to the United States Transuranium Registry. Rad. Prot. Dos.26,(1-4): 151-158 (1989).

McInroy, J.F., Boyd, H.A., Eutsler, B.C. and Romero, D. The U.S. Transuranium Registry report on the ${ }^{241} \mathrm{Am}$ content of a whole body: Preparation and analysis of tissues and bones. Part IV; Health Phys. 49: 598-621 (1985). 
Figure 5. ${ }^{238} \mathrm{Pu}$ urinary excretion for USTUR case 0259.

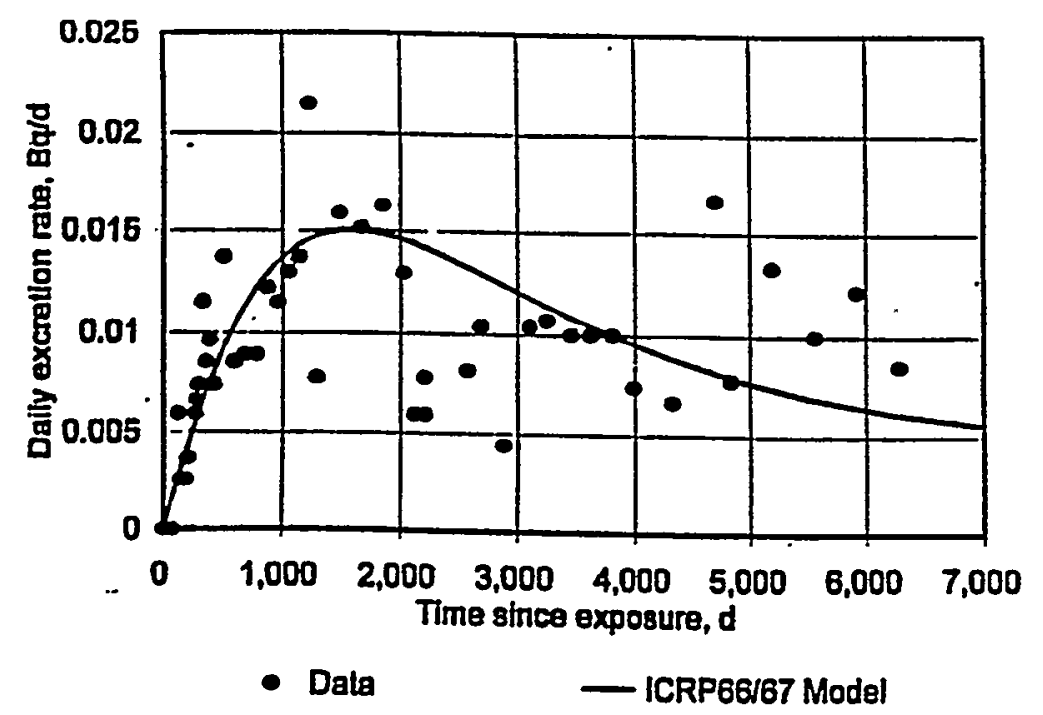

Table 5. Postmortem ${ }^{238} \mathrm{Pu}$ content of whole body.

\begin{tabular}{|c|c|c|c|c|c|}
\hline Tissue/Organ & $\begin{array}{l}\text { Wet Weight } \\
\text { (g) }\end{array}$ & $\begin{array}{c}\text { Ash Weight } \\
\text { (g) }\end{array}$ & $\begin{array}{c}\text { Activity } \\
(B q)\end{array}$ & $\begin{array}{c}\text { Distribution } \\
\text { (\%) }\end{array}$ & $\begin{array}{c}\text { Systemic } \\
\text { Distribution }^{\mathrm{a}}\end{array}$ \\
\hline Respiratory Tract & 1,455 & & 30 & 10 & (\%) \\
\hline Liver & 1,483 & & 137 & 48 & 53 \\
\hline Kidneys & 303 & & 0.31 & 0.11 & 0.12 \\
\hline Spleen & 213 & & 1.1 & 0.37 & 0.41 \\
\hline Smooth Muscle Organs & 2,079 & & 0.85 & 0.30 & 0.33 \\
\hline Striated Muscle & 28,054 & & 6.1 & 2.1 & 2.4 \\
\hline Other Muscle & 711 & & 1.2 & 0.42 & 0.47 \\
\hline Skin & 15,994 & & 2.4 & 0.83 & 0.92 \\
\hline Other Soft Tissue & 2,219 & & 1.8 & 0.63 & 0.71 \\
\hline Testes & 23 & & 0.04 & 0.01 & 0.01 \\
\hline Skeleton and Teeth & 9,806 & 3,270 & 106 & 37 & 41 \\
\hline Total Whole Body & 62,340 & 3,270 & 287 & 100 & 100 \\
\hline
\end{tabular}

Table 6. Postmortem ${ }^{238} \mathrm{Pu}$ content of whole body.

\begin{tabular}{llcc}
\hline Tissue/Organ & & $\begin{array}{c}\text { Wet Weight } \\
(\mathrm{g})\end{array}$ & $\begin{array}{c}\text { Activity } \\
(\text { Bq })\end{array}$ \\
\hline Lung & (left) & 599 & 8.5 \\
Trachea & (right) & 696 & 12.4 \\
Tracheal scraps & & 15.2 & 0.04 \\
Larynx & & 27.3 & 0.19 \\
Lymph nodes & (TBLN - 1) & 105.7 & 0.31 \\
& (TBLN - 2) & 0.6 & 0.20 \\
& (TBLN - 3) & 0.6 & 1.9 \\
& (TBLN - 4) & 1.3 & 0.48 \\
& (hilar - 1) & 1.3 & 0.12 \\
& (hilar - r) & 3.5 & 2.0 \\
\hline \multirow{2}{*}{ Total } & & 3.6 & 3.7 \\
\hline
\end{tabular}




\title{
A STUDY OF ACTINIDE MICRODOSE DISTRIBUTION IN SELECTED BONES USING ELECTRON PARAMAGNETIC RESONANCE (EPR)
}

\author{
Principal Faculty Investigator : John J. Russell
}

In conjunction with Marc Desrosiers at the National Institute of Standards and Technology (NIST), the Registries have been studying electron paramagnetic resonance (EPR) in bone from USTUR donors. Previous studies have demonstrated the production of radiation-induced paramagnetic centers in the hydroxyapatite crystal matrix of bone tissue. In addition, these paramagnetic centers have been shown to be long-lived (from months to years) and their induced numbers, radiation dose dependent. These induced paramagnetic centers have been used as markers of radiation exposure in radiation accidents (Desrosiers 1991) and to measure absorbed dose from administered radiopharmaceuticals (Desrosiers et al 1991).

Using EPR, the ability to detect doses as low as 1 Gray in bone samples as small as $100 \mathrm{mg}$ has been demonstrated. Compared to conventional autoradiography, the EPR method is the first direct technique for measuring and mapping the absorbed radiation dose in bone mineral matrix. To determine if EPR can provide a more exacting skeletal dose mapping technique than autoradiography, selected cortical and trabecular bone samples have been analyzed from two radium dial painter cases, each with a radiochemically determined total skeletal dose of $>50$ Gy from the many tissue samples maintained and available for further study at the NHRTR. De- pending on the success of the initial investigations, additional samples from the NHRTR collection will be examined.

Accordingly, four different bone samples, one trabecular and one cortical from the humerus of radium dial painter case \# 03-551 and samples of cortical bone from the fibula and ilium of radium dial painter case \# 05-958 were prepared for measurement by first cutting into approximately $4 \times 10 \mathrm{~mm}$ cylindrical pieces. The bone samples were rinsed in distilled water twice, air-dried, and then measured in a sensitive EPR spectrometer equipped with a sensitive microwave resonator. Preliminary examination of the spectra produced in all four samples indicated the presence of a signal from the organic component. However, in the ilium sample there was also an indication of a signal from a hydroxyapatite center (Fig. 6). Current work is underway to attempt to enhance this weak apatite center signal by removal of the larger organic component signal by Soxhlet extraction treatment with diethylenetriamine.

Acknowledgement: EPR measurements have been performed at NIST under the direction of Dr. Marc Desrosiers.

\section{References}

Desrosiers, MF. In vivo assessment of radiation exposure. Health Phys. 61(6): 859-861; (1991). 
Desrosiers, M.F., B.M. Coursey, M. J. Avila and N.J. Parks. Radiation dose. Nature 349:349-287 (1991).

Figure 6. EPR spectrum of ilium bone (USTUR \#03-551).

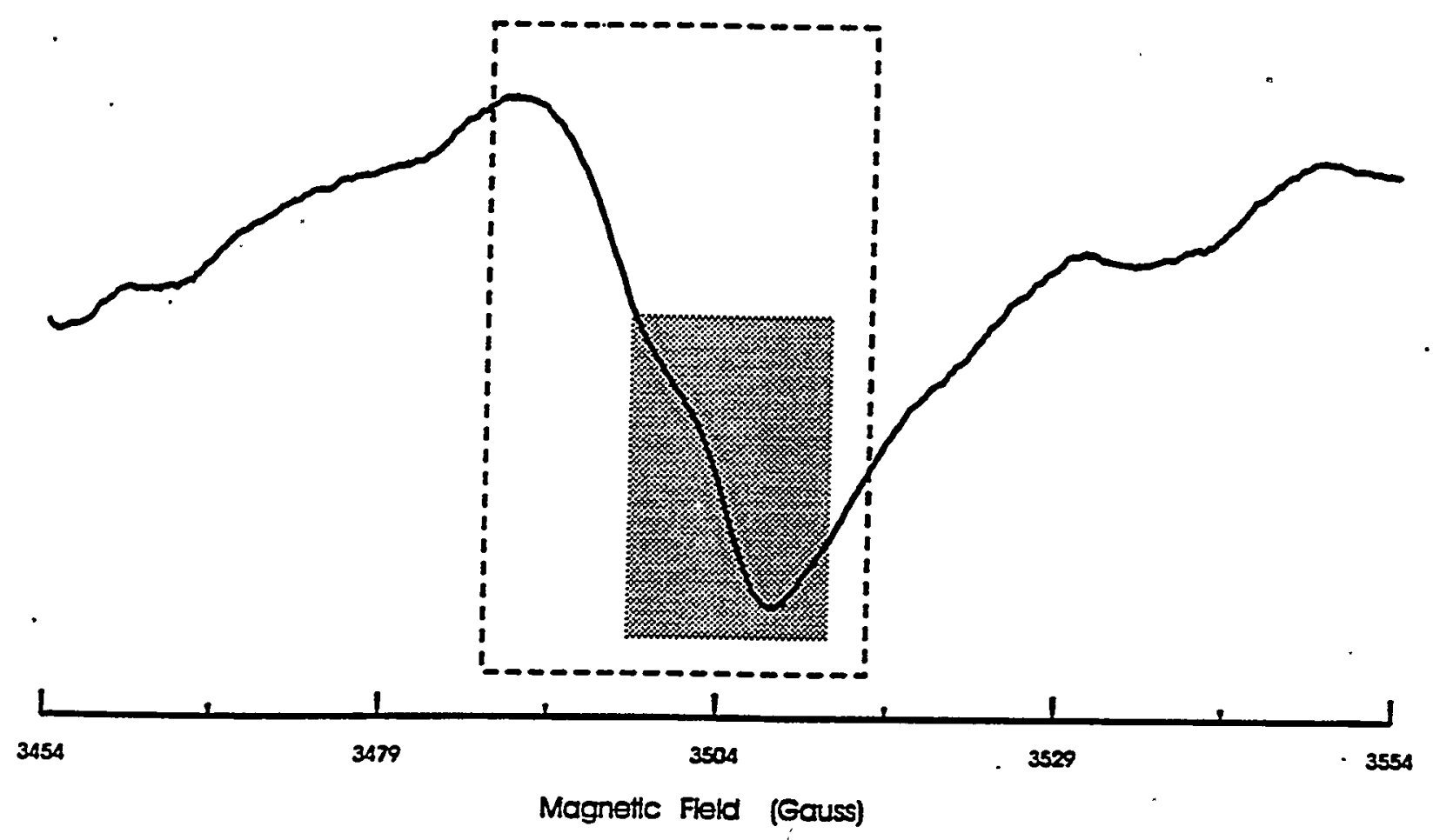




\title{
RADIOCHEMISTRY PROJECT
}

\author{
Principal Faculty Investigator: Roy H. Filby
}

\section{Radiochemistry Laboratory Facilities}

The start-up phase of the radiochemistry laboratories began during the last reporting period. The laboratory designed for handling, drying and ashing of human tissues (room 215) required remodelling before use. It was necessary to install approximately $30 \mathrm{~kW}$ of 208 volt new power for the large drying oven and the high-temperature, high-capacity, muffle furnace which operates up to $1100^{\circ} \mathrm{C}$. Also for both biohazard and radiological protection reasons, the gases and fumes from the oven and muffle furnace during drying at $120^{\circ} \mathrm{C}$ and ashing at $450^{\circ} \mathrm{C}$, respectively, needed to be vented directly to the atmosphere through the roof of the building. This required significant remodelling in room 215 and the mounting of fans on the roof of the building. The remodelling was completed in March 1995 although the exhaust system had to be modified several times to prevent large temperature variations in the muffle furnace which were the result of too much air being pulled through the furnace.

The laboratory was set up as a posted biohazard area and an exposure control plan for bloodborne pathogens was written in July 1995. This plan was approved by the WSU Department of Environmental Health and Safety in August 1995 following certification of the biosafety cabinet for handling of human tissues.

\section{LANL Sample Inventory}

Considerable effort was expended in the reporting period in determining which samples from LANL required analysis or required re-analysis (i.e. previously analyzed at LANL but with unacceptable results). A total of 2004 solutions of tissues from USTUR cases was received from LANL in June 1994. A manifest from LANL was not received until October 1994 at which point samples were unpacked from crates and segregated into USTUR cases (samples had been packed indiscriminately). In December 1994, many discrepancies between the sample inventory and LANL manifest were identified and 75 samples were identified as either not received or received but not the LANL inventory listing. All samples were entered into a USTUR sample database which was completed in June 1995.

Laboratory notebooks which were essential for performing re-runs, or analyses of solutions which had not been analyzed by LANL, were received in part in April 1995 and complete set of notebooks was received in July 1995. Even at the time of writing this report (January 1996), problems still remain with some cases for which re-runs have been requested but for which we do not have samples (e.g. 67 solutions from case 0262). Whether these samples were inadvertently shipped to the NHRTR or were not shipped from LANL remains undetermined. Samples may not have been taken for analysis or may not have been dissolved In August 1995, 400 additional solutions from cases 0769 and 1002 were received from LANL, complet- 
ing the sample transfer from LANL to WSU.

To improve tracking of samples in the USTUR program and to avoid the multiple identification numbers used in the LANL system, a unique seven-digitidentification numbering system for each sample such that all containers, solutions, analysis data, and computer files contain certain specific information about the sample. This number has the form:

aaaabbb

Where

aaaa $=$ four digit case number $b b b$ $=$ three digit serial number assigned at sample preparation (NHRTR).

Additional identifiers beyond the seven-digit sample number are used to indicate analyte (i.e. Pu, Am, U, or Th), reanalysis, re-count etc. The laboratory analysis number is directly tied to the case number, minimizing misidentification.

\section{Validation of radiochemical procedures}

To validate the transfer of the radiochemical analysis program of the USTUR from LANL to WSU, four intercomparison programs were set up. The overall intercomparison program was set up to use LANL data on previously analyzed samples, thus eliminating the need for costly additional analyses by LANL and expediting the validation process. Professor Ahmed Nevissi at the University of Washington (UW) was selected to participate in the intercomparisons as an independent third laboratory. The intercomparisons were:
Alpha Spectroscopy Intercomparison: Both WSU and the UW analyzed electrodeposited disks containing ${ }^{241} \mathrm{Am}$ and ${ }^{238 / 239} \mathrm{Pu}$ previously analyzed by LANL. This was completed during the previous reporting period (Kathren et al 1994).

Spiked Solution Intercomparison: Solutions spiked with known activities of contamination-free NIST-traceable ${ }^{239} \mathrm{Pu}$ and ${ }^{241} \mathrm{Am}$ were prepared at both the UW and at WSU. These solutions were coded, exchanged between the two laboratories, and analyzed using the USTUR Radiochemistry Project procedures at WSU and using UW procedures at the UW. This intercomparison was completed in July 1995. In general the results show very good agreement between the UW and WSU over a wide range of activities. Detailed results from this intercomparison are discussed in Appendix G.

Analysis of LANL Solutions: Both the UW and WSU analyzed $8 \mathrm{M} \mathrm{HCl}$ solutions from cases $0246\left({ }^{241} \mathrm{Am}\right.$ case) and $0637\left({ }^{238 / 239} \mathrm{Pu}\right.$ case) which had been previously analyzed and reported by LANL. Soft tissues and bone samples were included in this intercomparison. This intercomparison was designed to validate the radiochemical separation procedures in both laboratories. Results from the study were completed in September and, in general, show excellent agreement among the three laboratories. Details of the statistical procedures used and the results from the three laboratories are included in Appendix $\mathrm{G}$.

NIST Standard Reference Materials NIST SRM 4351, Human Lung, and SRM 
4352, Human Liver, were analyzed for ${ }^{241} \mathrm{Am},{ }^{238+239} \mathrm{Pu},{ }^{235+238} \mathrm{U}$ and ${ }^{232} \mathrm{Th}$ using the USTUR Radiochemistry Project procedures developed for the routine analysis of USTUR tissue samples. No significant differences were found between the WSU values and the NIST values at the $95 \%$ confidence interval. Detailed results are given in Appendix G.

\section{Analysis of samples from cases 0469 and 0637}

The first analyses of LANL solutions using USTUR procedures were performed as part of the method validation project. Some of the samples used in the LANL/ WSU/UW intercomparison study were taken from cases 0469 and 0637 since these cases had been partially analyzed at LANL prior to transfer of the program to WSU. Routine analyses of samples from cases 0469 and 0637 which had not been analyzed or required re-runs were completed in September 1995.

\section{Analysis of other LANL solutions}

The first priority of the USTUR Radiochemistry Project after validation of the radiochemical methods used at WSU was to begin analyzing the backlog of solutions which had not been analyzed by LANL. Solutions from several other cases which had not been analyzed by LANL were begun in June. As of September 30 the status of cases for which analyses were requested was as follows:

Case 0210: No samples received from LANL.

Case 0221: No samples received from LANL.
Case 0231: Samples to be analyzed.

Case 0260: Analyses completed and reported.

Case 0262: 198 samples require reanalysis. A total of 131 samples are in the Nuclear Radiation Center inventory; 67 samples have not been located and may not have been shipped by LANL.

Case 0469: Analyses completed and reported.

Case 0579: Chemistry in progress.

Case 0637: Analyses completed.

Case 0644: Analyses to begin in October.

Case 0648: Separations on 10 samples completed.

Case 0677: To be analyzed.

Case 0775: To be analyzed.

Case 0778: To be analyzed.

Case 0779: To be analyzed.

\section{Analysis of Case 0841}

Eleven tissue samples from case 0841 were received in August and this case was used to test out the tissue preparation, ashing and decomposition procedure. No major problems were experienced in the decomposition of these tissues and ${ }^{234+235+238} \mathrm{U}$ data were reported in August and September and entered into the USTUR database. 
USTUR Radiochemistry Project Policies and Procedures Manual

The radiochemical procedures adopted by the USTUR Radiochemistry Project were based on the procedures developed at LANL and described in LA10300-M (Gautier, M.A. 1995). However, a number of changes were made in the radiochemical separation methods and major changes were made in the alpha spectroscopy methods. These procedures were incorporated into a raiochemistry Policies and Procedures manual that was completed in September. The procedures cover all aspects of the analytical program from receipt of the sample at WSU to reporting of data, including Quality Assurance/Quality Control procedures. This manual will be reviewed and revised at appropriate intervals.

\section{Training}

All member of the staff either received radiation safety training during the previous reporting period or during the current period. All staff were also provided with a training program on the safe handling of human tissues containing bloodborne pathogens. This training was provided by the WSU Office of Environmental Health and Safety and is an integral part of the Biohazard Plan for the USTUR Radiochemistry Project which was approved by Environmental Health and Safety. All staff members have also received Hepatitis B vaccinations. Informal training was also provided for staff on the use of the alpha spectrometry system.

\section{Research and development programs}

Several research and development projects were started during the reporting period. The objective of these projects is twofold: a) to improve existing USTUR procedures for the determination of actinide elements in human tissues by replacing ion-exchange separation methods with faster and less waste-producing extraction chromatography methods; and b) to develop new analytical capabilities for the USTUR program. These research and development projects are summarized in Appendix F.

\section{References}

Kathren, R.L., L. A. Harwick, R. E. Toohey, J. J. Russell, R. E. Filipy, S. E. Dietert, M. M. Hunacek, C. A. Hall. The United States Transuranium and Uranium Registries. Report Period October 1, 1992-September 30,1993. Washington State University. USTUR0015-95 (1994).

Gautier, M. A., et al. Health and Environmental Chemistry: Analytical Techniques, Data Management and Quality Assurance, QCR100:1-280.7. LANL-10300-M. Los Alamos National Laboratory, Albuquerque, NM. (1995). 


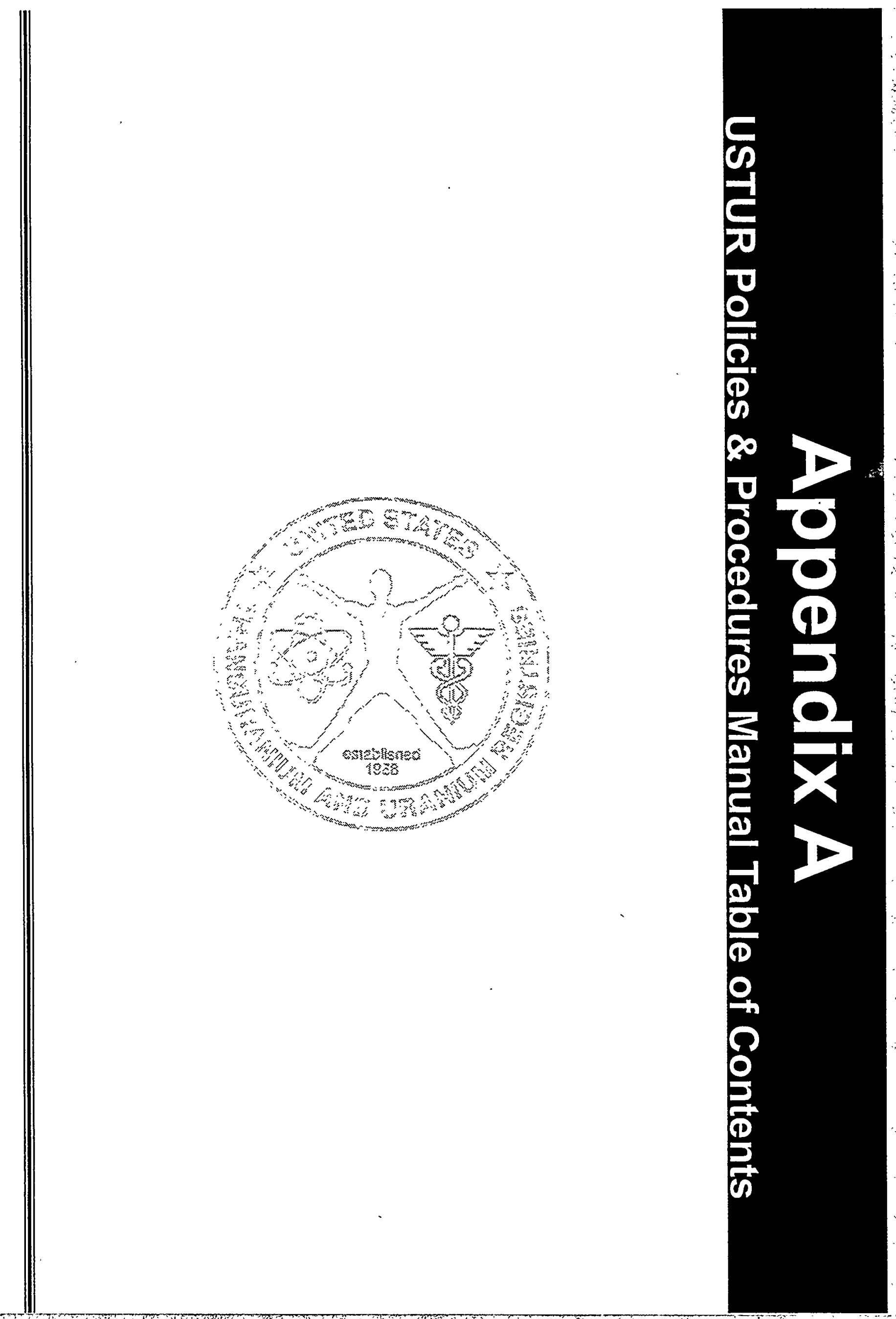

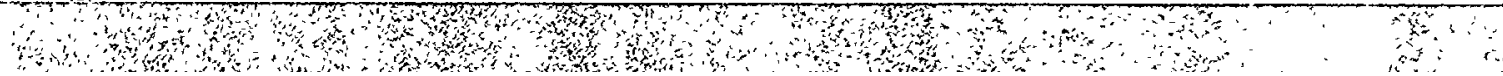




\section{USTUR Policies AND PROCEDURes MANUAL Table of Contents}

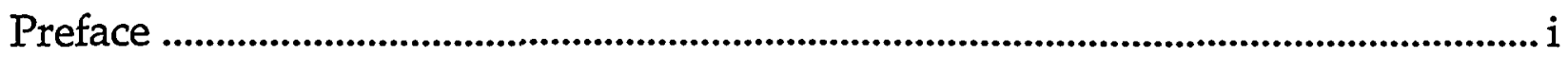

Table of Contents ................................................................................................................ ii

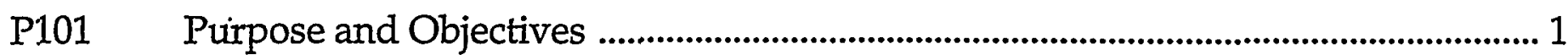

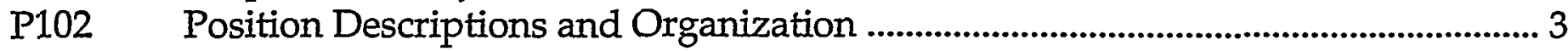

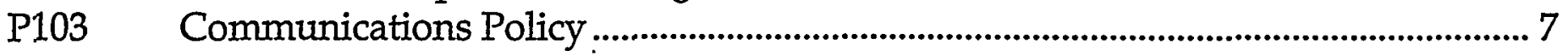

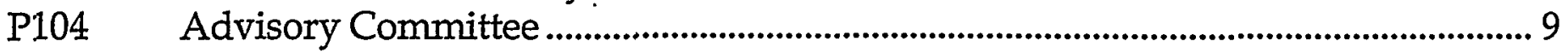

P105 Authorship on Manuscripts .......................................................................................... 11

P106 Scientific Collaboration and Data Access .......................................................... 12

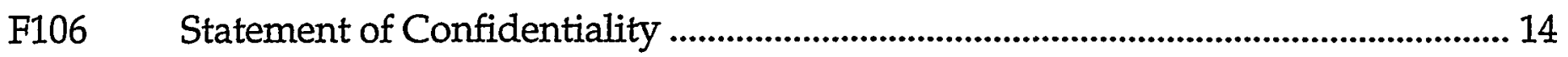

P107 Publications Policy ............................................................................................................ 15

R107 Publications Numbering System ................................................................................... 17

P108 Classified Time-off Policy .................................................................................................... 19

F108 Request for Time-off..................................................................................................... 20

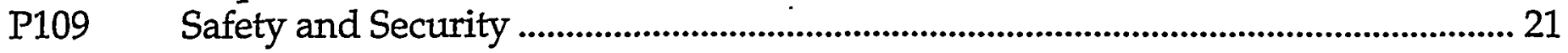

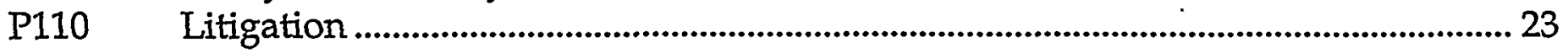

P150 Handling Donated Human Tissue ........................................................................... 24

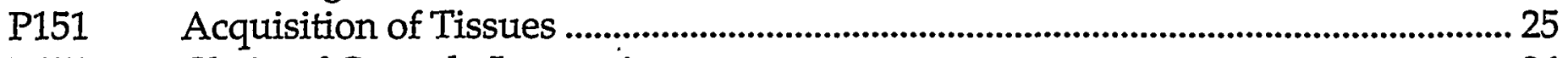

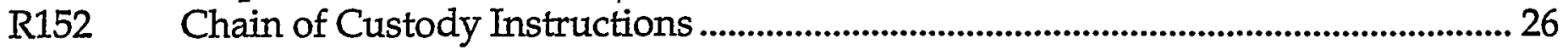

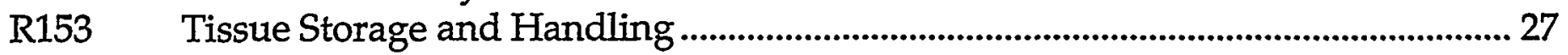

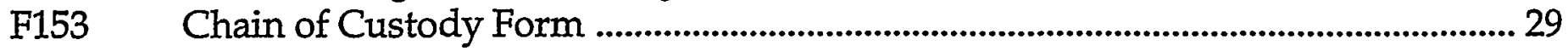

P154 Disposition of Donated Tissues ............................................................................................ 30

F200 Letter of Instruction for Registrant Family Members and Caregivers .................... 32

P201 Registrant Enrollment and Renewal ................................................................................ 33

R201 Registrant Renewal Procedure ...................................................................................... 35

P202 Criteria for Registrant Acceptance ................................................................................... 36

P203 Autopsies on Registrants .............................................................................................. 38

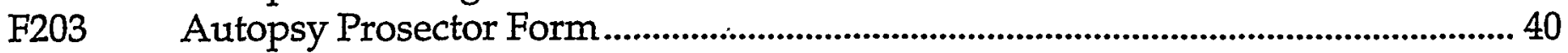

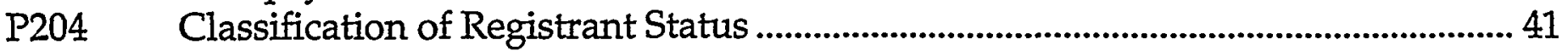

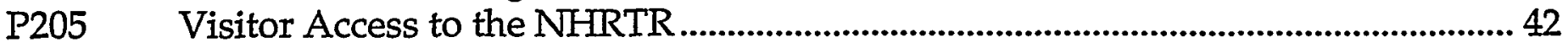

F205 Information and Informed Consent .............................................................. 43

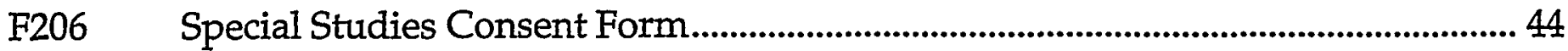

R401 Instructions to Pathologist.................................................................................................. 46

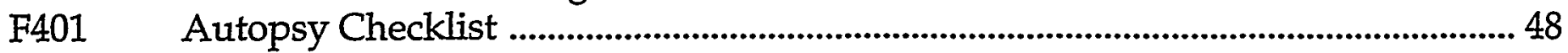

R402 Arranging for the Autopsy of a Deceased Registrant ............................................... 49

F402a Whole Body Specimen Worksheet ................................................................................. 51

F402b Routine Specimen Worksheet ............................................................................................. 56

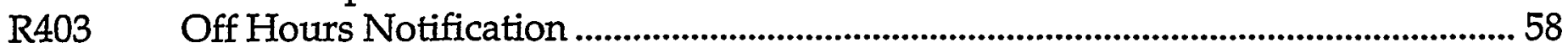

R500 Health Physics Data Coding and Entry .................................................................. 60

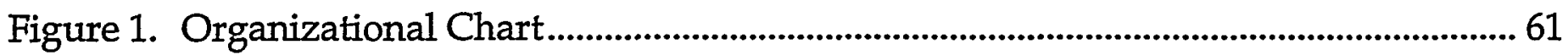




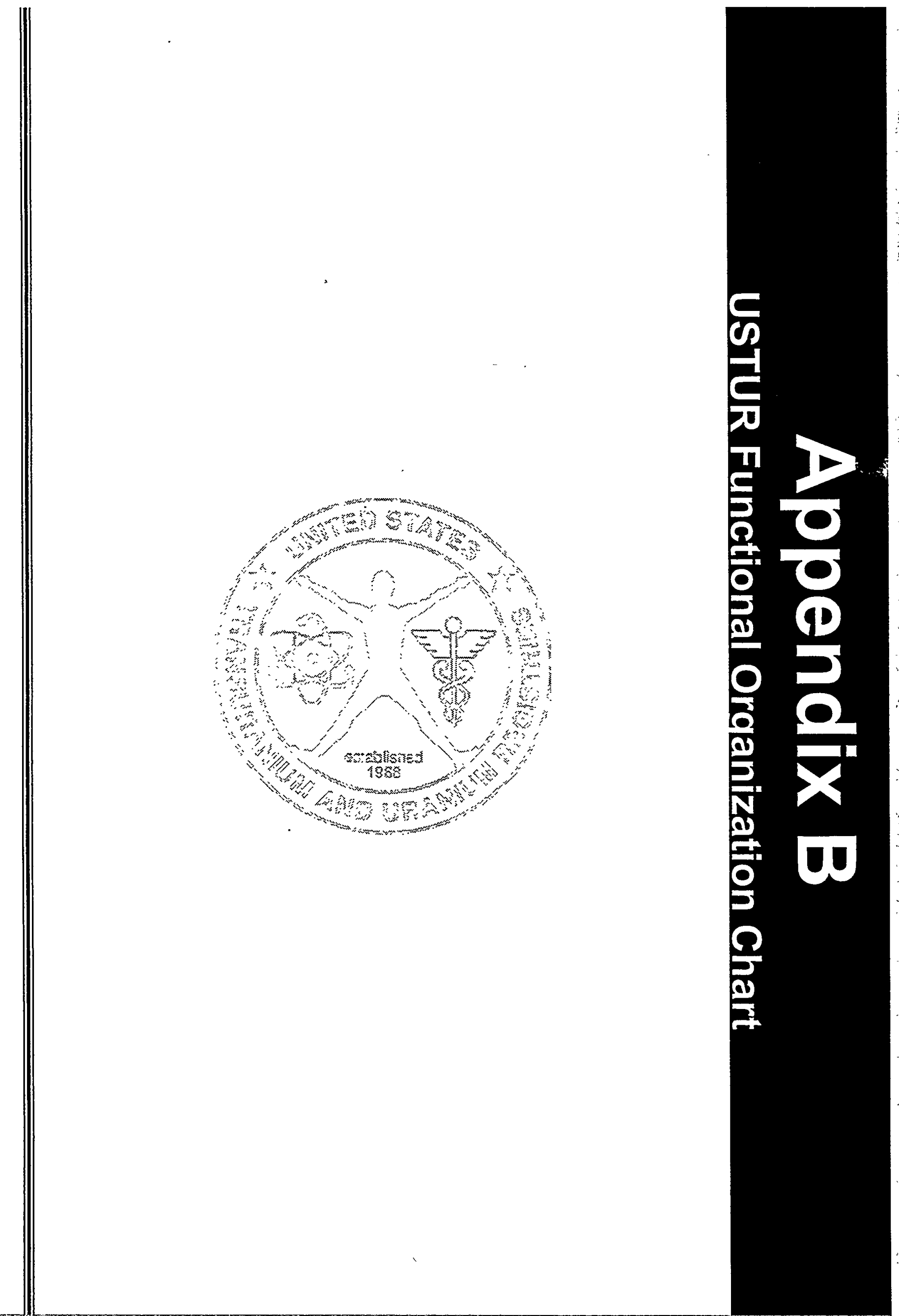




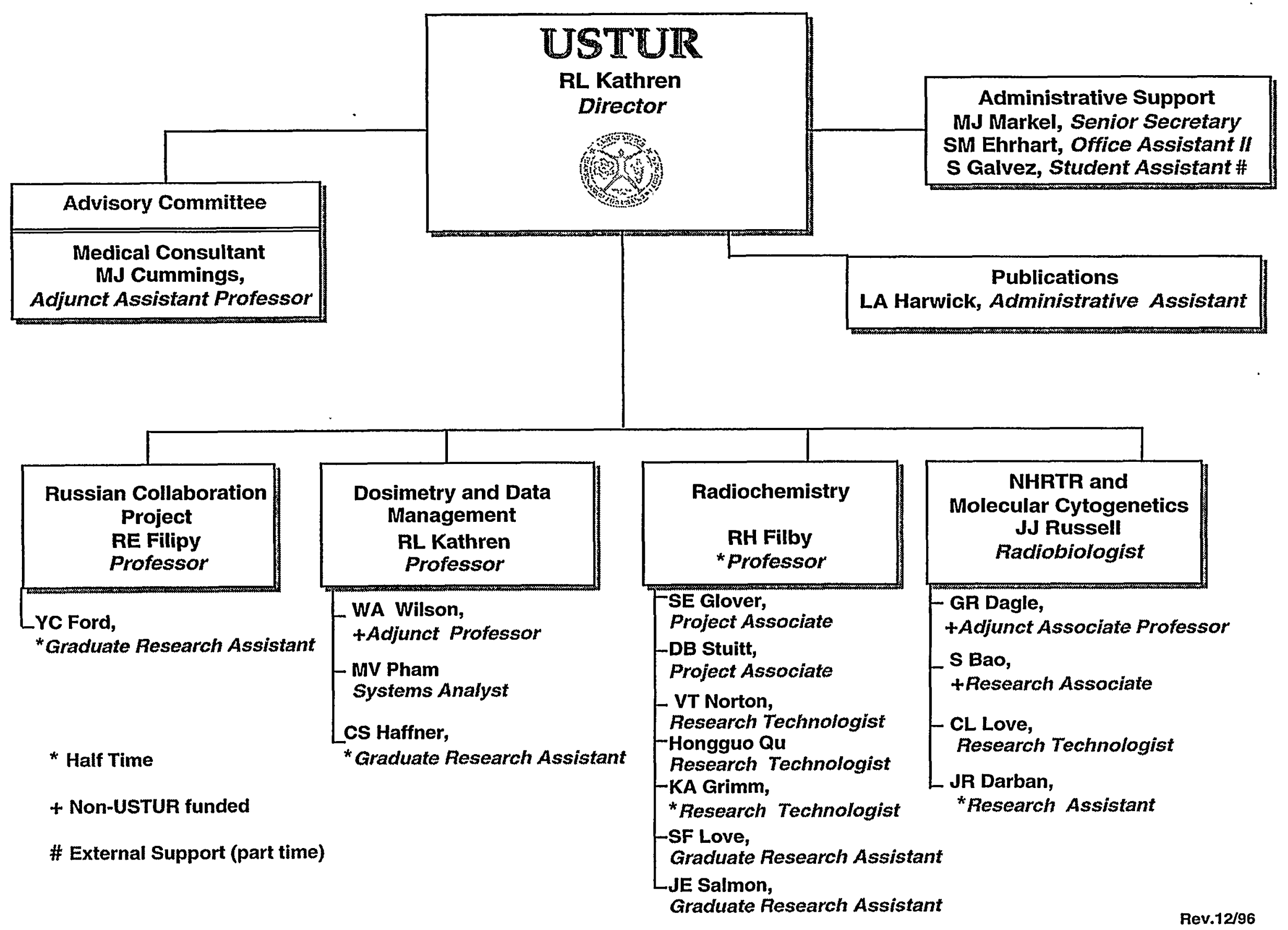




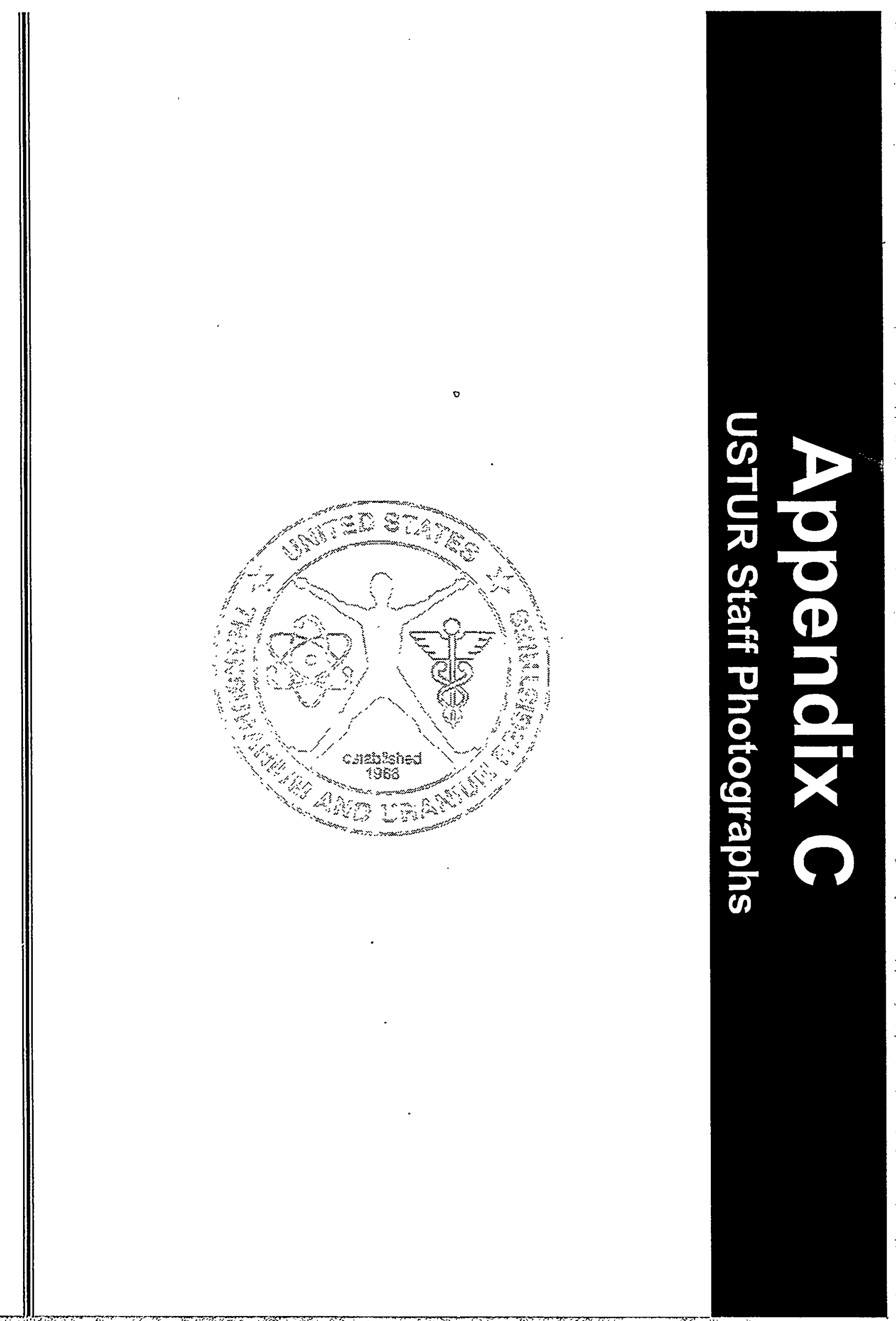


USTUR Faculty and Staff Photographs

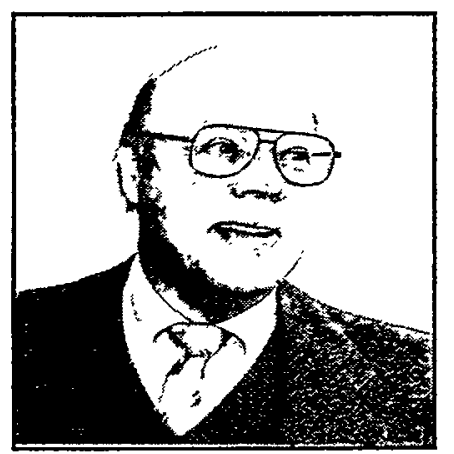

Ronald L. Kathren, Professor and Director

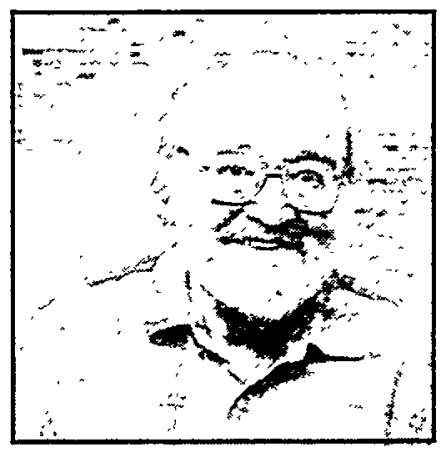

Royston H. Filby, Professor

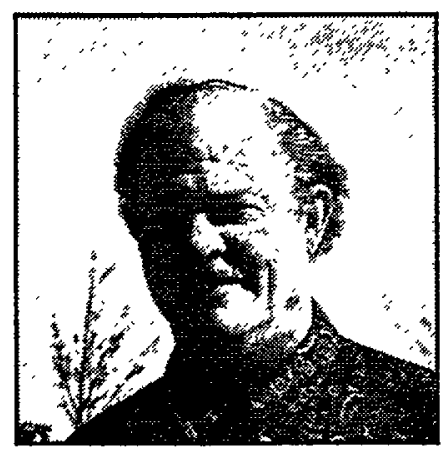

Michael J. Cummings, Adjunct Assistant Professor

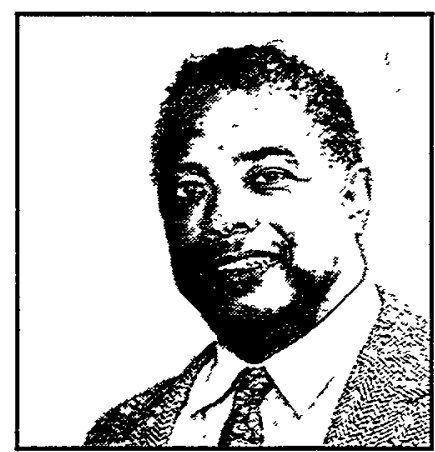

John J. Russell, NHRTR Curator and Radiobiologist

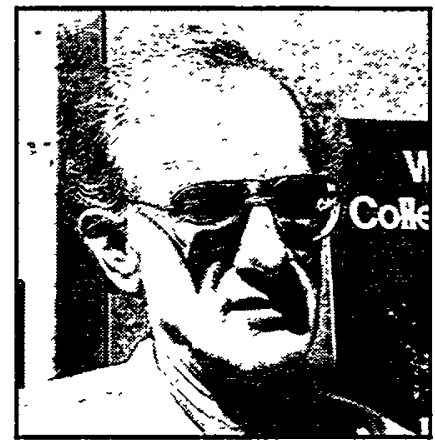

Walter A. Wilson, Adjunct Professor

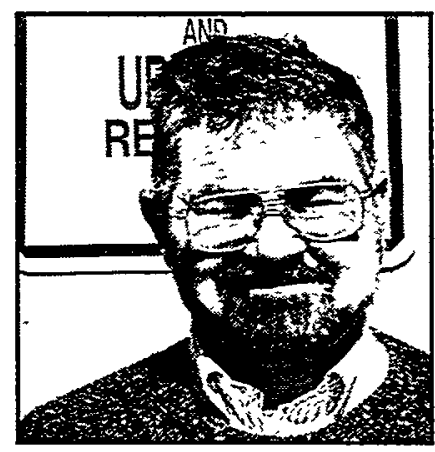

Gerald R. Dagle,

Adjunct Associate Professor

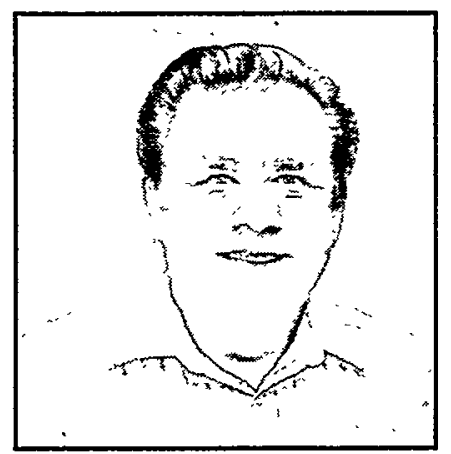

Ronald E. Filipy, Professor

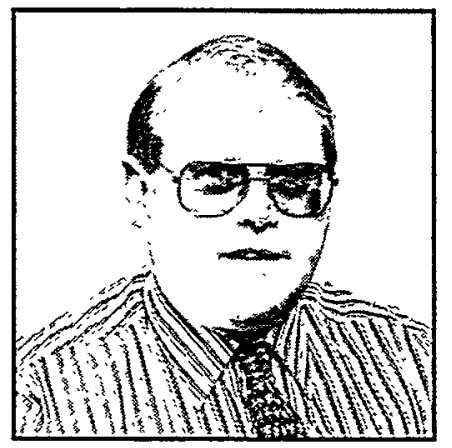

Anthony C. James, Associate Professor

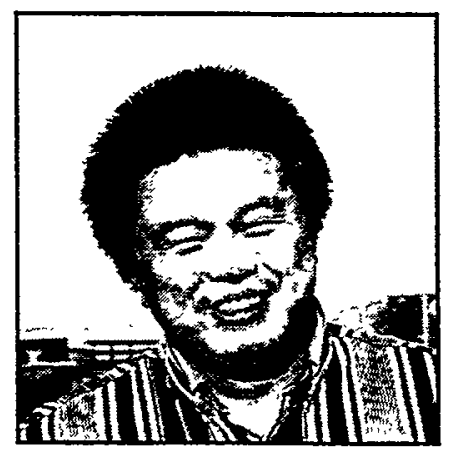

Shiping Bao

Research Assiociate 
USTUR Faculty and Staff Photographs

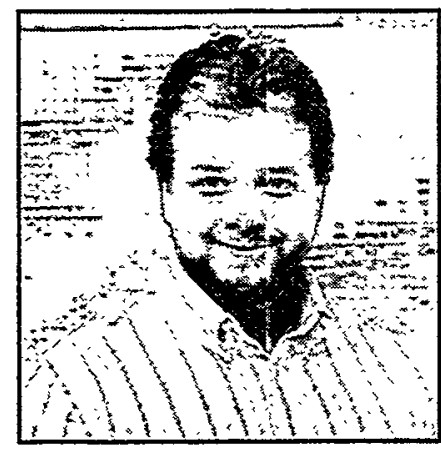

Samuel E. Glover, Radiochemist

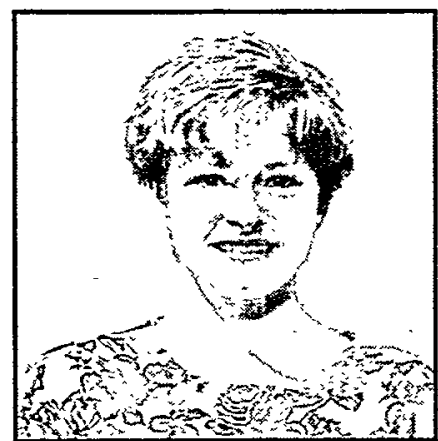

Lynn A. Harwick, Administrative Assistant

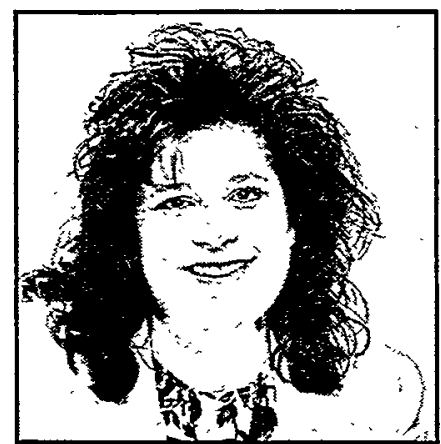

Susan M. Ehrhart, Office Assistant II

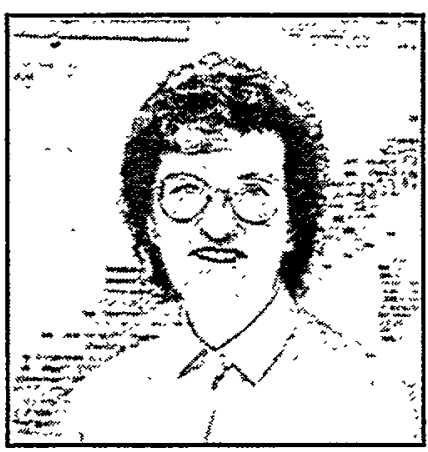

Dorothy B. Stuitt, Radiochemist

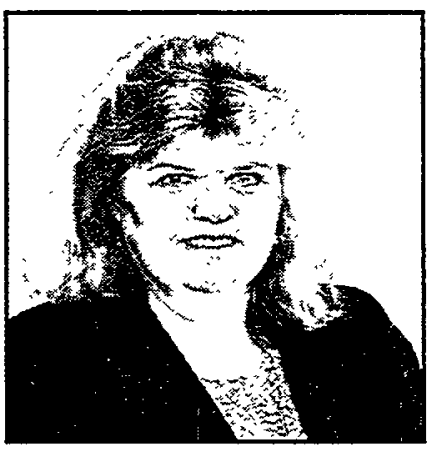

M. June Markel, Senior Secretary

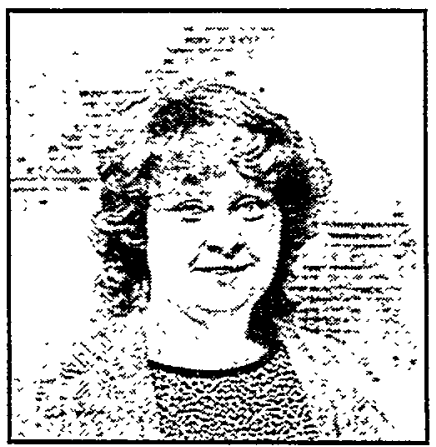

Patricia Waldo, Senior Secretary

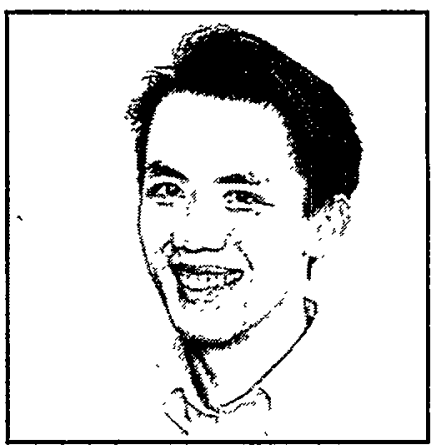

Minh V. Pham, Systems Analyst

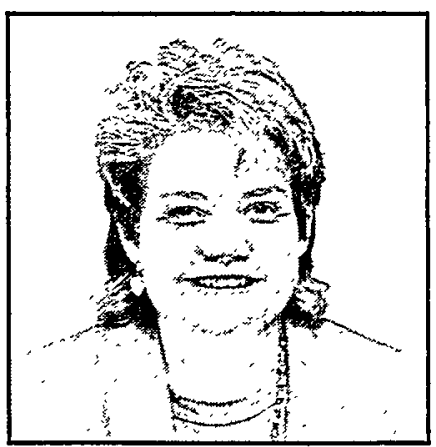

Cheryl L. Love, Research Technologist

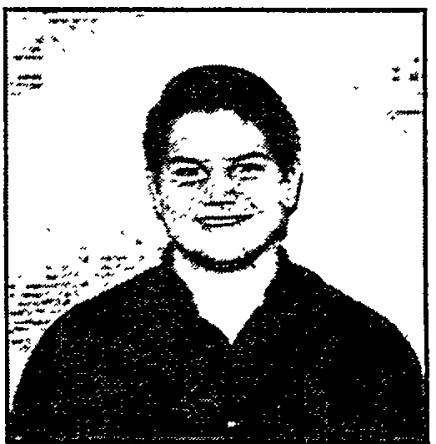

V. Thane Norton, Research Technologist 


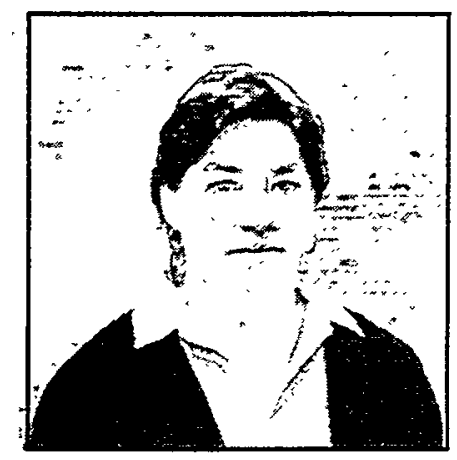

Catherine A. Grimm, Research Technologist

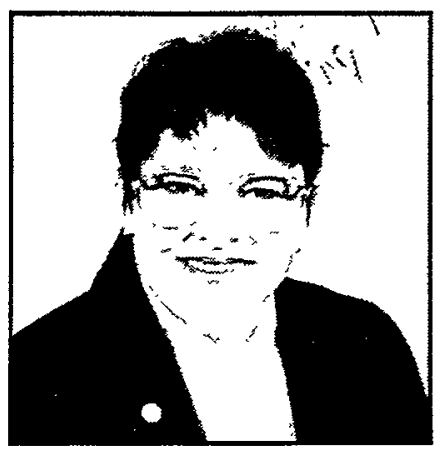

Cynthia S. Haffner, Graduate Research Assistant

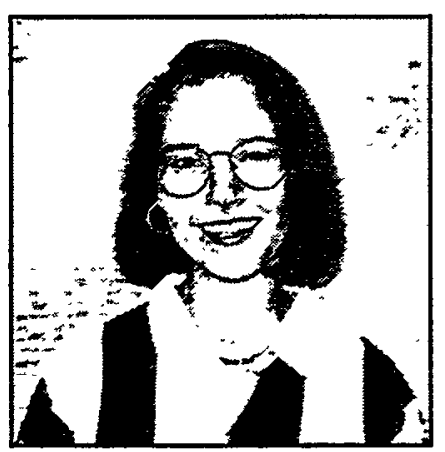

Johanna E. Norton, Graduate Research Assistant

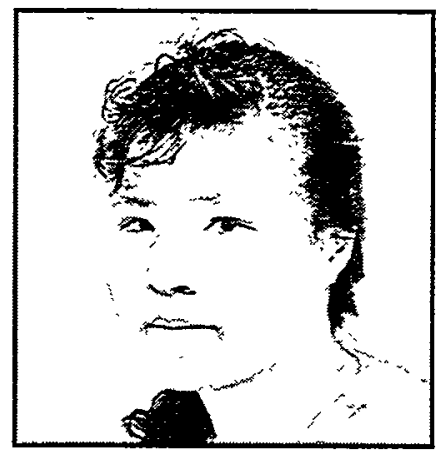

Yong C. Ford, Graduate Research Assistant

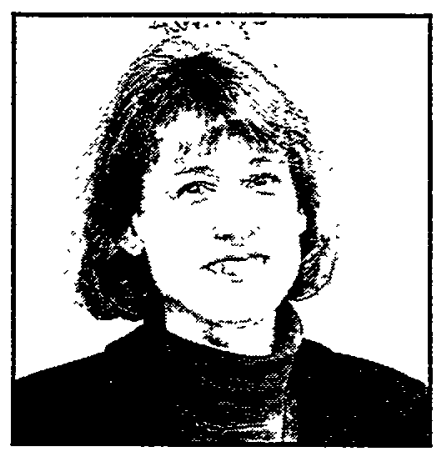

Mickey M. Hunacek, Graduate Research Assistant

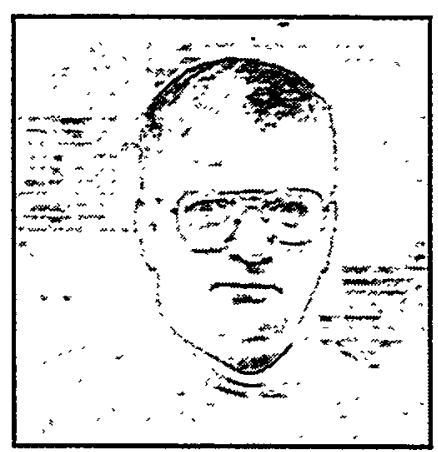

James Eliston, Graduate Research Assistant

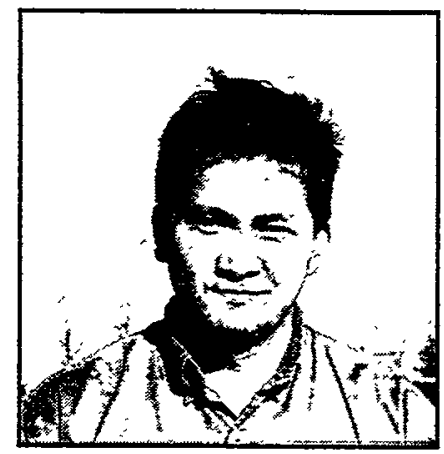

Ronald M. Suguitan, Graduate Research Assistant

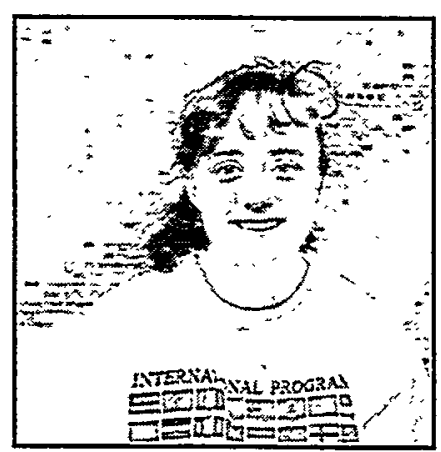

Suzanne F. Love, Graduate Research Assistant

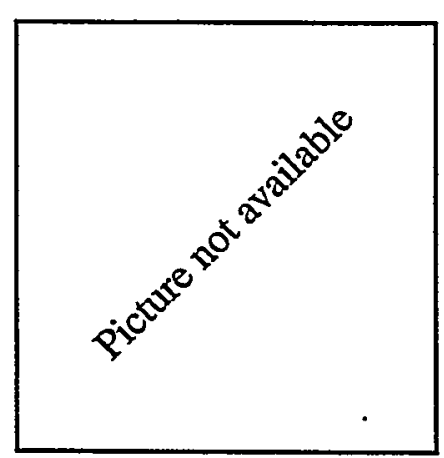

Jill Darban, Research Assistant 
USTUR Faculty and Staff Photographs

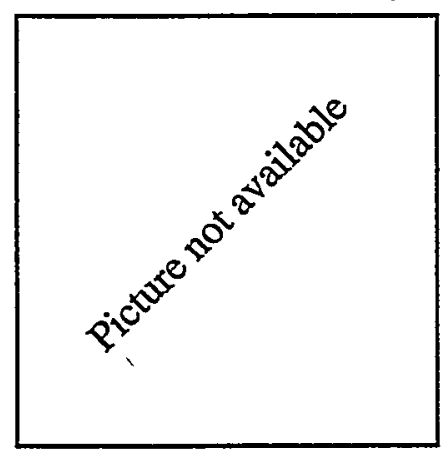

Sandra Galvez, Student Assistant

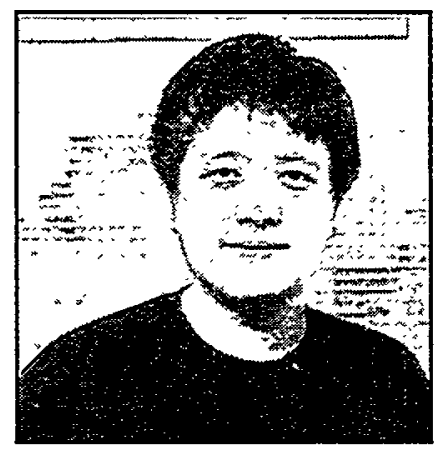

Honggo Qu, Student Employee 

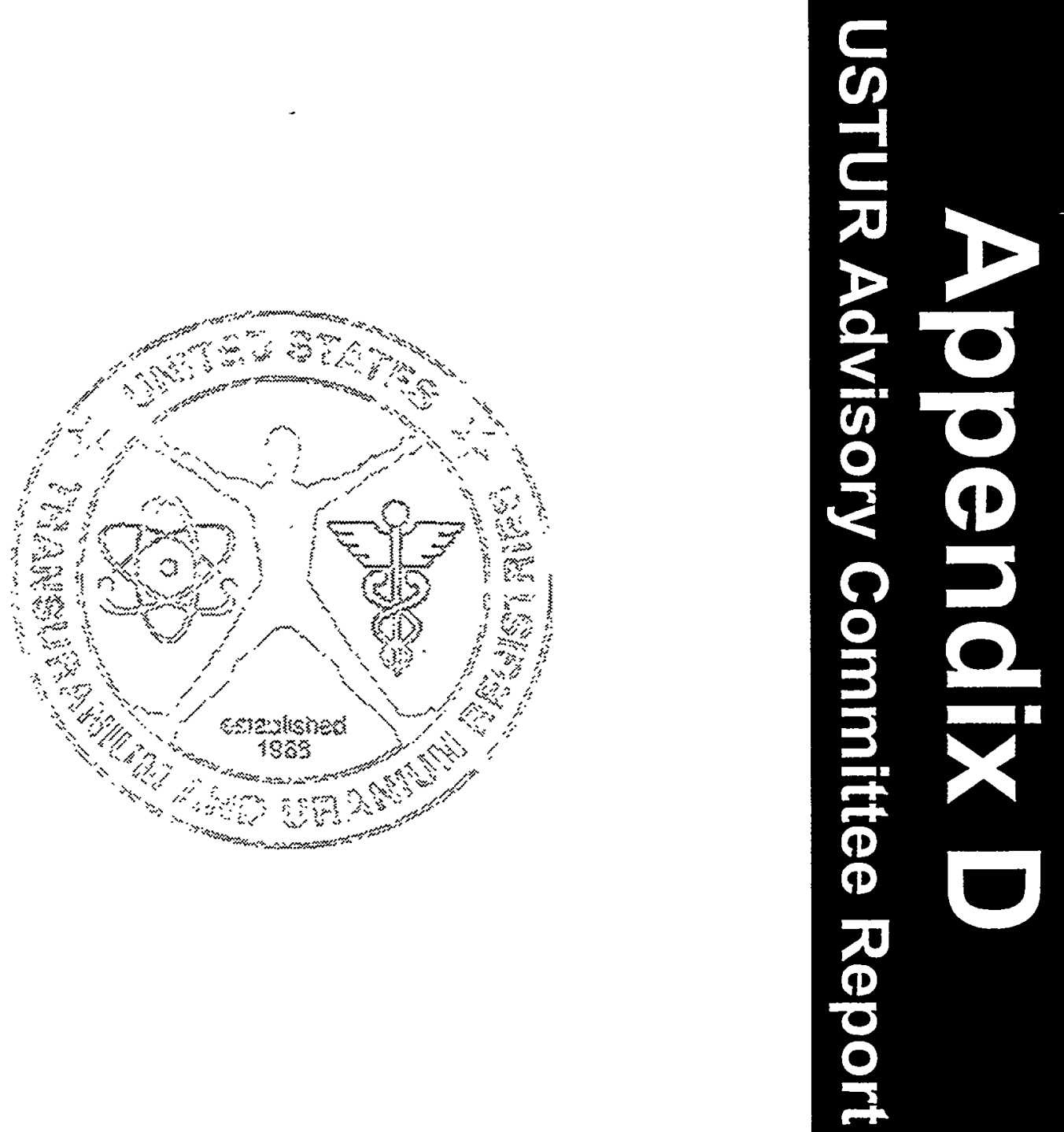


\section{5 \\ REPORT OF THE ADVISORY COMMMITTEE \\ TO THE \\ UNITED STATES TRANSURANIUM AND URANIUM REGISTRIES}

Keith Schiager, Chairman

\section{Venue:}

The Advisory Committee met at the University Inn, Moscow, Idaho on 17 and 18 October 1995. The meeting included a tour of the USTUR radiochemistry laboratories in the Radiation Center on the Washington State University campus in Pullman, Washington.

\section{Attendance:}

The meeting was called to order by Chairman Schiager at 8:30 am on 17 October 1995 with introductions of everyone present. All members of the Advisory Committee were present, i.e. Borje K. Gustafsson, Kenneth G. W. Inn, Bruce D. Lawson, Keith J. Schiager, Robert G. Thomas, MaryBelle Thompson and George L. Voelz.

Registries staff members present for part of all of the meeting included Ronald L. Kathren, Director and Professor of Health Physics; Ronald E. Filipy, Professor of Radiobiology; John J. Russell, Curator, National Human Radiobiology Tissue Repository (NHRTR); Michael Cummings, Medical Consultant; Royston H. Filby, Professor of Chemistry; Samuel E. Glover, Radiochemist; Dorothy B. Stuit, Radiochemist; and Lynn A. Harwick, Administrative Assistant. Additional Washington State University personnel in attendance for part or all of the meeting: Mahmoud M. Abdel-Monem, Dean, College of Pharmacy; Diana Scoles, Manager,
Finance and Administration, College of Pharmacy.

Guests present for all or part of the meeting included Ahmed Nevissi, Radiochemist, University of Washington and Chuck Watson, National Radiobiology Archives.

The Department of Energy was represented by Barbara G. Brooks, USTUR Program Manager, Office of Epidemiological and Health Surveillance. There was no representation from cooperating DOE laboratories.

In Memoriam of Roy Thompson

The Committee recognized the contributions of Roy Thompson to the field of radiobiology, and to the work of the Advisory Committee, by brief commentaries and a moment of silence.

\section{Review of the 1994 Committee Report}

The Committee reviewed the recommendations made in its 1994 report and received comments from the USTUR staff on progress made in several areas. The remarkable progress in the analytical laboratory capabilities and quality control procedures, the significant improvements in the long-range plan, and the extensive additions to the computer data base, includtion by the Committee. 


\section{National Radiobiology Archives (NRA)}

Chuck Watson, NRA Director, gave a short presentation on the purpose and status of the NRA. The NRA collects and stores data on tens of thousands of animals used in radiobiology studies, and makes these data available to researchers for reanalysis or new investigations. The collection includes "tons of documents," some slides, tissue blocks in The NRA collaborates with Dr. Gerber, who represents the Commission of the European Communities, in compiling a similar database for experimentation done in Europe over the past several decades.

DOE Perspective

Barbara Brooks reviewed the current status and future projections of DOE funding. She also commented on the results of the human experimentation review conducted by the DOE and the report recently released by the GAO. With respect to the Advisory Committee, she recommended that the Committee define its own role more clearly and that it encourage the Registries to focus its research on current concerns with the health protection of workers.

\section{Staff Presentations}

Director Kathren reviewed the activities and accomplishments of the Registries during the preceding year. He noted that $93 \%$ of deceased registrants have no medical records and $37 \%$ have no dosimetry records. He raised the question as to whether there should by a policy of recontacting selected inactive registrants to recapture scientifically important cases. The Committee concurred with this concept and suggested that review of all registrants, active as well as inactive, to identify sci- entifically important cases would be worthwhile.

Professor Filipy reviewed the status of cooperative studies with the Mayak Industrial Association, Russian Federation. The study involves a large population with high internal and external doses from a large accidental release from a processing plant. The Committee expressed the opinion that the doses (up to two orders of magnitude larger than any of the USTUR registrants) would make the finding of significant biological effects much more likely than in the USTUR population. It is not yet clear whether there will be a possibility to share tissue specimens or only some data.

John Russell presented data on the status of whole body donors alive as of 10/1/ 95 , and on the expected number of registrant deaths during the coming year. It seems clear that stringent prioritization will be necessary to ensure that the scientifically important cases are identified and accepted, and that they can be analyzed in a timely manner.

John Russell also presented an overview of collaborative studies that are currently being performed, or are proposed for future funding, utilizing materials available from the USTUR registrants or from NHRTR tissues.

\section{Tour of Radiochemistry Laboratories}

The Committee was treated to a very informative tour of the Nuclear Science Center and the Radiochemistry Laboratories. Essentially all of the radiochemistry staff was present, with ample time allowed for the Committee members to raise questions and become acquainted with the staff. 


\section{MAJOR TOPICS OF DISCUSSION AND COMMTTEE RECOMMENDATIONS}

\section{Radiochemistry Laboratories}

The Registries is to be congratulated for the progress made in reestablishing its radiochemistry capabilities: 1) new, dedicated laboratory space and equipment have been obtained, installed and made operational; 2) qualified laboratory personnel were being trained; 3 ) a variety of analytical procedures and radiochemical separations methods have been documented; 4) research and developments of new analytical techniques were being pursued; and 5) a quality assurance program, including second party cross-check with the University of Washington has been initiated on sion requirements should be established for each project prior to initiation of work.

The overall up-front planning of all projects should include input from all research participants on establishing the objectives and the execution of subsequent steps - including sampling strategies, sample preservation, subsampling techniques, analytical accuracy and precision requirements, statistical analysis, and interpretation. Financial resources are too scarce to simply employ the undefined "best effort." The ANSI N13.30 draft standard offers a minimum set of accuracy and precision criteria for radiobioassay laboratories. Certain registries projects, however, will require higher levels of accuracy and precision than those specified in ANSI N13.30 to meet the interpretive needs of the work, and these requirements should be defined to avoid generation of inadequate or erroneous data. It is also important to establish accuracy and precision requirements with the external cross-check, reference and QA laboratories. This is necessary so that the laboratory can plan and price the degree of effort required to meet the needs of the Registries' program.

\section{Advisory Committee Recommendation}

Documented Procedures

Each procedure should be reviewed by experts to assure that a competent analyst could execute the instructions and satisfactorily meet the stated objective of the process.

As an example, Procedure USTUR 070, Preparation of Tracers, should be rewritten as a set of instructions to generate high quality tracers. The current procedure does very little in terms of detailed instructions to this end. Furthermore, there are several steps that could be easily taken to greatly improve the quality of tracers, e.g. 1) prepare dilutions gravimetrically, 2) use flame-sealed glass vessels for longterm solution storage, and 3) verify dilutions with measurements of adequate precision.

\section{Advisory Committee Recommendation}

Recommendation on

Quality Assessment

The Registries should establish a means of conducting measurement quality assessments. Assessment of process quality should be serviced by internal or external experts. In either case, quality 
assessment personnel must be independent of routine measurement process to provide independent evaluations.

Quality assessments are conducted through "blind" testing of the analytical process through "blank", replicate and well-prepared reference samples. Interpretation of assessment results must be made against established accuracy and precision criteria that are periodically reexamined. Although quality assessment personnel can work closely with the process personnel, they should ultimately report directly to the Director of the Registries. Quality assessment is an important component in the logic of quality assurance and necessarily requires strong commitment from upper management and adequate financial support.

A second benefit of using an experienced external laboratory for quality assessments is that they can also serve as a reference laboratory for special samples, or backup laboratory capacity under extraordinary circumstances.

\section{Advisory Committee} Recommendation

\section{External Measurement Assurance Programs}

In addition to verifying analytical methods with reference materials, the Registries' radiochemistry group should participate in appropriate tracer standards, alpha spectra evaluations and LANL solution analyses. These efforts must be continued to meet the Registries' current and future technical needs.

\section{Advisory Committee \\ Recommendation}

Analytical Requirements

As a minimum, accuracy and preciexternal measurement assurance programs (MAPS).

Unfortunately, not all of the existing MAPs fit the Registries' needs well: a) the EPA Cross-check Program is primarily designed to support water analyses; $b$ ) the USEML QAP is designed for soils, sediments, vegetation and perhaps air filters; c) the NIST-NEI Traceability Program is designed for nuclear power plant radiochemistry; d) the IAEA Intercomparisions (Seibersdorf/Monaco) materials include soils, sediments, vegetation, water and animal tissue; e) the DOELAP is a pilot test phase and will have both in-vivo and in-vitro (urine and feces) test samples; and f) the NIST natural-matrix radionuclide SRM intercomparisons are limited to lung, liver and bone matrices. The Registries' radiochemistry program would derive benefits through judicious selection of matrix intercomparison for participation.

Recommendation on Reference Materials: Five or more replicate analyses should be used to adequately evaluate the accuracy and precision of a method.

While the results of measurements on NIST SRMs are encouraging, two analyses are statistically inadequate to draw the conclusion that the methods used have been validated. ANSI N13.30 suggest the use of five or more replicate analyses. A secondary benefit from these mea- 
surements is an estimate of "best case" accuracy and precision. This information can be used to establish realistic accuracy and precision requirements for individual projects or redesign the measurement protocols to meet the need of the Registries' projects.

\section{Advisory Committee Recommendation}

\section{Reference Method}

A guaranteed reference sample dissolution, radiochemical purification and measurement method should be established to help validate new methods and to be used for special or high visibility samples.

Although the LANL procedures were adopted and new radiochemical methods are being developed it is important to establish a "bombproof" method for reference. An "unquestioned" sample dissolution is extremely important because the fundamental assumption that radiochemists rely on for quantitative analyses is that the tracer and analyte are completely homogenized. If this condition is not met, the resulting data will not be valid. The method of choice is high temperature fusion. Although messy, difficult and labor intensive, this technique is highly regarded and should be added to the Registries' radiochemistry skills.

\section{EXPOSURE RECORDS, RECRUIT- MENT AND REGISTRATION}

\section{Advisory Committee Recommendation}

The Director and senior staff should place the highest priority on developing personal contacts and rapport with appropriate health physics personnel at registrants' employer sites to facilitate identification of prospective new registrants and recovery of appropriate exposure data on new and existing registrants. The Committee recommends soliciting a liaison person at each participating DOE site, preferably an individual designated as such by the manager of the Health and Safety Division, or equivalent.

Both, the USTUR staff and the Advisory Committee recognize that adequate exposure records are essential to the scientific value of any specific registrant. Registrants are currently accepted on the basis of a "documented" actinide intake; however, according to the Director, there are no dosimetry records for $37 \%$ of deceased registrants, and exposure records are missing or incomplete for many active and inactive living registrants. This constitutes a serious deficiency in the scientific value of the current value of the current registrants.

The Committee believes that the dosimetry status of all registrants, active or inactive, should be reviewed to determine if the exposure information is sufficient to support scientific use of tissue analyses. Where data are lacking, greater effort should be devoted to obtaining the missing information. In the case of inactive registrants with adequately documented scientifically interesting exposures, an effort should be made to reenlist these individuals. More intensive efforts should also be made to identify and recruit individuals with well documented, interesting intakes. The priorities for these efforts should be based on the potential scientific 
value of the information to be obtained from the registrant's donation. The primary sources of most exposure records are the health physics (including "bioassay" and/or "dosimetry"), industrial hygiene and safety organizations of the registrant's employer. In the case of accidents or injuries, however, valuable information may be contained in the registrant's medical or personnel files, although most of the information in these files may be irrelevant to the registrant's exposure. Because of the effort needed to retrieve the relevant data, some means must be found to obtain the assistance of the site personnel. If backing of the effort could be obtained from someone in DOE with sufficient authority, top-down directives to provide the assistance might be effective. Providing direct labor support, in the form of a temporary loan of a person, might be another possible approach to retrieving information.

The Advisory Committee believes that the level of trust and confidence of employees enjoyed by staff physicians at participating laboratories places them in a unique position to encourage potential registrants. To take advantage of this situation, however, the staff physicians must first be convinced of the value of the Registries, and the specific nuclides, modes of exposure, and minimum levels of deposition of interest to the Registries need to be clearly enunciated. The Advisory Committee believes that personal contact be a peer physician may be the most effective way to gain the attention and cooperation of these staff physicians. Although a personal services contract has been established with Dr. Michael Cummings, it is only for approximately one per month, which the Committee believes that partici- pation in the regular meetings of the medical directors of DOE laboratories by a physician on the Registries' staff, and personal visits to medical departments of participating laboratories, could significantly improve recruitment and registration effectiveness.

The Committee believes that developing personal rapport with one or more appropriate individuals at each of the major DOE registrants' employer sites should be considered one of the highest priorities of the Director and senior staff of the Registries. Form letters and other official requests by correspondence have been shown to be ineffective. Without the personal contacts and sharing of the labor, suitable exposure records will continue to be elusive.

\section{Advisory Committee Recommendation}

\section{RUSSIAN COLLABORATION}

Collaborative research with the Russian Federation and the Joint Coordinating Committee for Radiation Effects Research (JCCRER) should be continued, and at an increased pace is feasible. The Registries should seek to integrate the research efforts of Ronald Filipy and John Russell to work with the Dosimetry Registry of the Mayak Industrial Association (DRMIA) to maximize our understanding of dose-effect relationships following radiation exposure of humans.

There is an agreement between the United States and the Russian Federation governments that is under the surveillance 
of a Joint Coordinating Committee for Radiation Effects Research (JCCRER) that is comprised of upper-level officials from each country. The US representation is from the Department of Energy (DOE), the Nuclear Regulatory Commission (NRC), Health and Human Services (HHS), and the Department of Defense (DOD); there are four representatives from the Russian Federation. The US component is comprised of political appointees and not front line scientists. In keeping with governmental organizations, there are several subcommittees: Executive Committee, Scientific Review Group, a group of Principal Investigators, and Project Research Teams. Dr. Ron Filipy has prime responsibility for the USTUR work that is associated with this program, with collaboration of Professor Kathren and his staff. The prime scientific involvement of the USTUR is under the topic of Occupational Dosimetry, a fitting obligation for this team.

In addition to the organizational complex described above, there is an organization called the Dosimetry Registry of the Mayak Industrial Association (DRMIA), operated by the institute of Biophysics of the Russian Federation. In general terms, the objective from the USTUR viewpoint is to establish respectable and analytically sound methods for tissue sampling from exposed individuals, the radiochemical plutonium and americium), and to build a database which will include the results obtained from the exposed Russian workers and those exposed in the United States. The DRMIA currently has dosimetric data on 1500 workers, 1000 of which have estimated body burdens of $>1500 \mathrm{~Bq}$
( $>40 \mathrm{nCi}$ ) compared with about 350 deceased individuals in the USTUR, with body burdens of $<500 \mathrm{~Bq}(12 \mathrm{nCi})$. Total tissue samples from the two institutions is approximately 40,000 . The strength that the additional data from the DRMIA will add to those data from the USTUR is without question.

Dr. Filipy presented data to the Committee showing the results of some plutonium tissue analyses from the USTUR and the DRMIA. It was clear from his presentation that the two sets of data are complimentary, as the tissue concentrations (shown for liver) are all essentially higher than those from the USTUR, in terms of $\mathrm{Bq}$ per weight of tissue. Most cases in the USTUR are in the range of $0.03-30 \mathrm{~Bq} / \mathrm{kg}$ while most of those in the DRMIA fall between 100 and $10,000 \mathrm{~Bq} / \mathrm{kg}$. There is some overlap of results be tween 30 and $300 \mathrm{~Bq} / \mathrm{kg}$. Although Filipy did not present skeletal data, his charts indicated a concentration ratio of plutonium in bone to that in liver to be about 0.25 for both USTUR and DRMIA data over estimated residence times to 40 years post-exposure.

The greatest advantages for collaboration between the USTUR and the DRMIA are the increase in number of cases and the broader range of exposures it provides. The disadvantages are the ever-present problem of having direct access to the Russian data; this problem has shown little progress in this or other areas of inter-governmental collaboration. There is a generic mistrust involved and post-cold war movements have not been encouraging. This sharing of basic data 
with the Russian scientists is one of the major problems the USTUR has and will continue to have with being able to merge all data on tissue analysis. For instance, even if data are presented on the tissue concentrations of plutonium in liver and bone, information concerning the individual exposure conditions (how, where, why) may not be readily forthcoming. However, it appeared to the Committee that Dr. Filipy and the staff have done a highly commendable job in getting the data they already have and it would appear with time that this cooperative venture will pay high dividends for both countries.

\section{EXPANDED RESEARCH EFFORTS}

One area of some concern to the Committee was the significant expansion into sub-cellular research. The questions may be stated as follows: does this area of research fit into the program goals of the USTUR and where does it belong in the list of priorities that need emphasizing to reach those program goals? One direction the Committee thought might be appropriate to emphasize was an incorporation of John Russell's laboratory techniques into an analysis of tissue samples from the Russian exposure cases. There must be a wealth of biological data buried in these tissues, which if liberated could be correlated with dosimetric findings for a given tissue. Major questions arise, however, as to whether such samples could be obtained from the Russian scientists and whether the tissues had been maintained at a sufficiently low temperature (say, $-70^{\circ} \mathrm{C}$ ) to enable meaningful molecular-biological analyses. If the samples could be available and could be used for such analyses, then it seems to the Committee that a golden opportunity exists to obtain information that will never again be possible to retrieve and that this should be pursued with vigor. The best orientation of this vigor is not clear to the Committee and can only be decided by those more closely involved, both at the USTUR and the DRMIA, and probably more importantly, the JCCRER. One direction Russell emphasized that could be extremely important to pursue is that of biodosimetry, perhaps using some of the available in situ hybridization techniques that could be pursued and/or developed which could be very useful in correlating latent damage to the causative radiation dose. In summary on this aspect, the Committee agrees that John Russell's research is first class and at the forefront, but is concerned with the priorities and that it may be difficult to find funding in these times of tight budgets.

\section{Advisory Committee \\ Recommendation}

USTUR Policies and Procedures Manual

USTUR Policy 104, USTUR Advisory Committee, should state in section 5 that the agenda for the annual meeting of the Committee shall be developed jointly by the Director and the Chair of the Committee.

A draft revision of USTUR Policy 104 was distributed to the Committee at the meeting. The changes from the previous version were minimal. The Committee believes that the policy should state that the Chair will work jointly with the Director to develop the agenda, as is currently be- 
ing done.

\section{Advisory Committee Recommendation}

Terms of Appointment

The Registries should clarify the terms to which current members have been appointed.

Several members have not been contacted during the third year of their term regarding reappointment, and received no letter of reappointment. Some correspondence and documents from the Registries have contained conflicting information regarding terms of appointments. The Committee believes that the terms of the appointment should be treated some what more formally by the Registries' staff.

\section{Advisory Committee Recommendation}

\section{LONG-RANGE PLAN}

The Long-Range Plan should clearly identify the essential purpose of the Registries and the specific goals that must be accomplished to achieve that purpose. It should then address in detail the processes for reaching those goals, i.e. the specific tasks that must be performed and the priorities and costs associated with those tasks.

The current Long-Range Plan is improved substantially over previous versions. The Plan is intended to be a living document and should be reviewed and modified as needed to meet the needs of the Registries. The descriptive sections on "Background" and "Goals and Objectives" are well done. The several planning sections (Near Term, Intermediate and Longer Term) could be read more easily if functional heading were used within these sections

The Plan should represent the staff's thinking about future work loads, especially on the basic research goals. The number and types of volunteers needed, and the projected death rates by year bases on ages of current volunteers, should be included. Such numbers would help in estimating the future work load of the radiochemistry laboratory.

Recruitment of cases with specific radionuclide depositions, like $\mathrm{Pu}-238, \mathrm{Cf}-$ 252 or Cm-244, may be possible with special efforts similar to the Thorotrast cases.

Interest in special cases should be identified for special recruitment efforts. Placing priorities on the existing cases will also assist in directing the order of the work load. The Plan should try to focus efforts along these directions.

The problems of obtaining occupational histories and exposure records of registrants, which were detailed in the meeting, should be discussed in the Plan. Whatever work is being planned or done in this area should be included. Provision for future dosimetry updates, including at the time of death, should also be presented.

The Plan does no make a distinction between the basic core work (essential) which is funded and future work (desired) which could be considered unfunded 
under current objectives. The Committee is perturbed when it sees more work in the latter category than in the former. One heading in each section of the Plan (as suggested above) might identify those activities for which the Registries plan to seek future funding, and their various priorities. In these days of limited research funding, efforts to diversify support could pay big dividends and should be part of the Plan.

\section{EXECUTIVE SESSION}

Keith Schiager was re-elected to continue as chair, with Kenneth Inn elected as vice-chair. The executive session was primarily devoted to discussion of the topics to be addressed as Committee recommendations. The Committee also returned to the subject of representation by the participating DOE laboratories which had been discussed earlier in the open meeting. We concluded that the invitations should come from the Committee, and that we should obtain from the Director a list of the Registries' site contacts or representatives well in advance of the meeting to facilitate planning and providing invitations.

\section{Advisory Committee Recommendation}

Laboratories Representatives

The Committee recommends that the meeting should be two full days in order to cover all relevant business. .

A slightly longer meeting is needed to cover thoroughly the items of concern to the Committee. Further, if DOE site representatives are invited, we should have some time to receive feedback as well as to inform them of the benefits of the Registries' programs.

\section{Adjournment:}

The meeting was adjourned at 12:15 PM on 18 October 1995. Dates for the next meeting were not set, although sometime in October 1996 is probable. 
USTUR Publications and Presentations

October 1, 1994 to September 30, 1995

Publications

Bair, W.J., M.R. Bailey, F.T. Cross, R.G. Cuddihy, P. Gehr, A.C. James, J.R. Johnson, R. Masse, M. Roy, and W. Stahlhofen. International Commission on Radiological Protection (ICRP) Human respiratory tract model for radiological protection. ICRP Publication 66. Ann. ICRP 24 (1/3); 1994.

Birchall, A., N.S. Jarvis, A.C. James, and G. Akabani. Algebraic functions to approximate the fractions of energy absorbed by target tissues in the 1994 ICRP respiratory tract model. National Radiological Protection Board. NRPB-M573; 1995.

Brodsky, A., R.L. Kathren, and C.A. Willis. History of the medical uses of radiation: Regulatory and voluntary standards of protection. Health Phys. 69:783-824; 1995.

Dagle, G.E., R.E. Weller, R.E. Filipy, C.R. Watson, and R.L. Buschbom. The distribution and effects of inhaled ${ }^{239} \mathrm{Pu}\left(\mathrm{NO}_{3}\right)_{4}$ deposited in the liver of dogs. Health Phys. (in press).

Filipy, R.E. and R.L. Kathren. Changes in soft tissue concentrations of plutonium and americium with time after human occupational exposure. Health Phys. 70:153-159; 1996.

Filipy, R.E. and R.L. Kathren. Changes in soft tissue concentrations of plutonium and americium with time after human occupational exposures. (Abstract) Health Phys. 66:S73; 1994.

Filipy, R.E., R.L. Kathren, and J.F. McInroy. Relative concentrations of plutonium and americium in the liver, testes, and thyroid gland. (Abstract) Health Phys. 62:S17; 1994.

Filipy, R.E., R.L. Kathren, J.F. McInroy, and R.A. Short. Soft tissue concentrations of plutonium and americium in occupationally-exposed humans. Health Phys. 67:477-485; 1994.

Filipy, R.E., R.E. Toohey, R.L. Kathren, and S.E. Dietert. Deterministic effects of ${ }^{241} \mathrm{Am}$ exposure in the Hanford americium accident case. Health Phys. 69:338-345; 1995.

Hall, C.A. and R.E. Filipy. Estimation of skeletal deposition of plutonium from analysis of a selected bone subset. (Abstract) Health Phys. 66:S26; 1994.

Hofer, K.G. and S. Bao. Low-LET and High-LET radiation action of ${ }^{125}$ I Decays in DNA: effect of cysteamine on micronucleus formation and cell killing. Radiat. Res. 141:183-192; 1995. 


\section{USTUR Publications and Presentations \\ October 1, 1994 to September 30, 1995 \\ (cont'd)}

Hopke, P.K., B. Jensen, C. Li, N. Montassier, P. Wasiolek, A.J. Cavallo, K. Gatsby, R.H. Socolow, and A.C. James. Assessment of the exposure to and dose from radon decay products in normally occupied homes. Environ. Science and Tech. 29(5):1359-1364; 1995.

Hui, T.E., A.L. Brooks, and A.C. James. Microdosimetry of micronuclei induction and cell killing in mammalian cells irradiated in vitro by alpha particles. Int. J. Radiat. Biol. (in press).

Hunacek, M. and R.L. Kathren. Alpha radiation risk coefficients for liver cancer, bone sarcomas, and leukemia. Health Phys. 68:41-49; 1995.

James, A.C., G. Akabani, A. Birchall, N.S. Jarvis, J.K. Briant, and J.S. Durham. International Commission on Radiological Protection. Annexe H: Absorbed fractions for alpha, electron, and beta emissions. In: Human respiratory tract model for radiological protection. ICRP Publication 66. Ann. ICRP 24(1/3); 1994.

James, A.C. and A. Birchall. New ICRP lung dosimetry and its risk implications for alpha emitters. Radiat. Prot. Dos. 1995.

James, A.C., M. Roy, and A. Birchall. International Commission on Radiological Protection. Annex F:Reference values for regional deposition. In: Human respiratory tract model for radiological protection. ICRP Publication 66. Ann. ICRP 24(1/3); 1994.

James, A.C., W. Stahlhofen, G. Rudolf, J.K. Briant, M.J. Egan, W. Nixon, and A. Birchall. International Commission on Radiological Protection (ICRP). Annexe D: Deposition of Inhaled Particles. In: Human respiratory tract model for radiological protection. ICRP Publication 66. Ann. ICRP 24(1/3); 1994.

Kathren, R.L. Book Review: Low-Level environmentalradioactivity: Sources and evaluation by Richard Tykva and Josef Sabol. Health Phys. 69(6):990-990; 1995.

Kathren, R.L. Pathway to a Paradigm: The linear nonthreshold dose response model in historical context. Health Phys. 70:621-635; 1996.

Kathren, R.L. Primeval X-ray Protection: X-rays and X-ray protection before there were state regulators: The first fifty years of $\mathrm{x}$-ray protection, proceedings of the 1995 Annual national meeting of the conference of radiation control program directors, San Antonio, Texas, May 7-10, 1995, CRCPD Publication; 95/4:6-18; 1995.

Kathren, R.L. Postmortem verification of internal dose. In Internal Radiation Dosimetry. Ed. O.G. Raabe. Madison, WI: Medical Physics Publishing; 1994, pp. 517-528. 
USTUR Publications and Presentations

October 1, 1994 to September 30, 1995

(cont'd)

Kathren, R.L. Toward improved biokinetic models for actinides: The United States Transuranium and Uranium Registries, A twenty-five year status report. Radiat. Prot. Dos. 53:219-227; 1994.

Kathren, R.L. The United States Transuranium and Uranium Registries. Chapter 5 in radiation and public perception, ACS advances in chemistry Eds. J.P. Young and R.S. Yalow, Washington: American Chemical Society, series No. 243: 459-482; 1995.

Kathren, R.L. and A. Brodsky. Historical development of radiation protection. Book chapter in radiology centennial physics history. Ed. P. Almond. (in press).

Kathren, R.L., J.B. Gough, and G.T. Benefiel. The Plutonium Story: The Journals of Professor Glenn T. Seaborg. Columbus, Ohio: Battelle Press; 1994.

Kathren, R.L. and L.A. Harwick. The United States Transuranium and Uranium Registries. Report of the Period October 1, 1993 - September 30, 1994. USTUR-0036-95. College of Pharmacy, Washington State University, Richland, WA (August 1995).

Kathren, R.L., L.A. Harwick, R.E. Toohey, J.J. Russell, R.E. Filipy, S.E. Dietert, M.M. Hunacek, and C.H. Hall. The United States Transuranium and Uranium Registries. Report of the period October 1, 1992 - September 30, 1993. USTUR-0015-95. College of Pharmacy, Washington State University, Richland, WA (September 1994).

Kathren, R.L., J.J. Russell, and A.C. James. Preliminary evaluation of the distribution and biokinetics of ${ }^{238} \mathrm{PuO}_{2}$ in a whole body donor to the USTUR. Health Phys. 68:576; 1995.

McInroy, J.F., R.L. Kathren, R.E. Toohey, M.J. Swint, and B.D. Breitenstein, Jr. Postmortem tissue contents of ${ }^{241} \mathrm{Am}$ in USTUR case 246. Health Phys. 69:318-323; 1995.

Medley, D.W., R.L. Kathren, R.E. Filipy, and A.G. Miller. Diurnal variation in urinary uranium levels. Health Phys. 67:122-130; 1994.

Park, J.F., R.L. Buschbom, G.E. Dagle, A.C. James, C.R. Watson, and R.E. Weller. Biological effects of inhaled ${ }^{238} \mathrm{PuO}_{2}$ in beagles. Radiat. Res. (submitted).

Priest, N.D., A. Freemont, J.A.M. Humphreys, and R.L. Kathren. Histopathology and ${ }^{241}$ Am microdistribution in the skeleton of USTUR case 246. Health Phys. 69:330-337; 1995.

Rudolf, G., R. Köbrich, W. Stahlhofen, and A.C. James. Regional deposition in man - A statistical and algebraic model. In: Inhaled particles VII. Eds. J. Dodgson and R.I. McCallum, Oxford: Pergamon Press:1-14; 1994. 


\section{USTUR Publications and Presentations \\ October 1, 1994 to September 30, 1995 \\ (cont'd)}

Russell, J.J., R.A. Guilmette, and R.L. Kathren. Autoradiographic localization of ${ }^{241} \mathrm{Am}$ in selected soft tissue samples from USTUR Case 246. Health Phys. 69:316-317; 1995.

Russell, J.J., R.L. Kathren, and S.E. Dietert. A histological kidney study of uranium and nonuranium workers. Health Phys. 70(4):466-472; 1996.

Russell, J.J., R.L. Kathren, R.A. Short, and J.F. McInroy. Long-term organ retention and pathology in a Thorotrast patient: A preliminary report. In: Health effects of internally deposited Radionuclides: Emphasis on radium and thorium. Eds. G. VanKaick, A. Karaoglou, and A.M. Kellerer. World Scientific; 1995.

Schlenker, R.A., R.E. Toohey, E.G. Thompson, and B.G. Oltman. Bone surface concentrations and dose rates 11 years after massive accidental exposure to ${ }^{241} \mathrm{Am}$. Health Phys. 69:324$329 ; 1995$.

Stannard, J.N. and R.L. Kathren. Radiation protection and medical practice with special reference to health physicists and the health physics society. Health Phys. 69(5):837:844; 1995.

Stark, A.A., J.J. Russell, R. Langenbach, D.A. Pagano, E. Zeiger, and E. Huberman. Localization of oxidative damage by glutathione-g-glutamyl transpeptidase system in preneoplastic lesions in sections of livers from carcinogen-Treated Rats. Carcinogenesis Vol. 15, No. 2:343; 1994.

Suslova, K.G., R.E. Filipy, V.F. Khokhryakov, S.A. Romanov, and R.L. Kathren. Comparison of the dosimetry registry of the mayak industrial association and the United States Transuranium and Uranium Registries: A preliminary report. Radiat. Prot. Dosim. (submitted)

Toohey, R.E. Biokinetics of Bone-seeking Radionuclides. In: Internal Radiation Dosimetry. Ed. O.G. Raabe. Madison, WI: Medical Physics Publishing; 1994, pp. 197-216.

Toohey, R.E. Measurement and analyses techniques for direct assessment of body radioactivity. invited paper for special issue on environment and waste management technology. Nuclear Technology (in press).

Toohey, R.E. and R.L. Kathren. Overview and dosimetry of USTUR Case 246. Health Phys. 69:310-316; 1995.

Wasiolek, P.T., S.D. Schery, J.E. Broestl, and A.C. James. Experimental and modeling studies of thoron decay products in outdoor air near the ground surface. Presented at the national radiation environment VI, Montreal, Canada, June 5-9, 1995. Science of the Total Environment. (in press). 
USTUR Publications and Presentations

October 1, 1994 to September 30, 1995

(cont'd)

Wasiolek, P.T. and A.C. James. Outdoor Radon Dose Conversion Coefficient in South-Western and South-Eastern United States. Radiat. Prot. Dosim. 59, 269-278; 1995.

Wasiolek, P.T. and A.C. James. Suitability of Radon Gas Concentration for Lung Dose Estimation Outdoors. Radiat. Prot. Dosim. (in press).

\section{Presentations}

\section{October}

- R.L. Kathren visited the Rocky Flats site and also moderated a Socratic discussion of radiation and chemical risks at a joint meeting of the local Denver chapters of the American Society of Safety Engineers, American Industrial Hygiene Association, Health Physics Society, Society for Risk Analysis, American Association of Occupational Physicians, and American Association of Occupational Nurses.

\section{November}

- R.L. Kathren presented "Ethical Considerations of Human Radiation Experimentation: A Health Physics Perspective" at the joint meeting of the Hoosier and Bluegrass Chapters of the Health Physics Society in Lexington, KY.

\section{December}

- R.L. Kathren presented "The United States Transuranium and Uranium Registries" to the President's Committee on Human Radiation Experiments.

- R.L. Kathren presented "The United States Transuranium and Uranium Registries" to the Agency for Toxic Substances and Disease Registry in Atlanta, GA.

- R.L. Kathren presented "The United States Transuranium and Uranium Registries" to the Advisory Board of the Agency for Toxic Substance and Disease Registry.

\section{February}

- R.L. Kathren presented "Radioactivity in Everyday Life" to Mathematics, Engineering and Science Achievement (MESA) students.

\section{March}

- R.E. Filipy participated in "The United States-Russian Federation Experience in Health Effects of Occupational Radiation Exposure" workshop in St. Petersburg, Florida.

\section{April}

- R.L. Kathren presented "Ethical Considerations of Human Radiation Experimentation: A Health Physics Perspective" as the Third Annual Newell Stannard Lecturer at the Annual Meeting of the Sierra Nevada Chapter of the Health Physics Society. 
USTUR Publications and Presentations

October 1, 1994 to September 30, 1995

(cont'd)

- R.L. Kathren presented "Environmental Radioactivity" to the California State Department of Health.

- R.L. Kathren presented "Radioactivity Labeled.Antibodies" to the Nưclear Medicine Research Working Group in Richland, WA.

May

- R.E. Filipy presented "The Collaboration Between the Russian and American Transuranium Registries" at the Interagency Nuclear Safety Review Panel Technical Interchange Meeting in Richland, WA, May 2-3, 1995.

- A.C. James presented "New ICRP Respiratory Tract Dosimetry" at the Interagency Nuclear Safety Review Panel Technical Interchange Meeting in Richland, WA, May 2-3, 1995.

- A.C. James presented "Dosimetry Modeling of a USTUR Whole Body Donor Exposed to ${ }^{238} \mathrm{PuO}_{2}$ Microspheres" at the Interagency Nuclear Safety Review Panel Technical Interchange Meeting in Richland, WA, May 2-3, 1995.

- R.L. Kathren presented "Changes in Radiation Protection Issues at Hanford and Beyond Since 1960" to the Columbia Chapter of the Health Physics Society in Richland, WA, May 2, 1995.

- R.L. Kathren presented "The U. S. Transuranium and Uranium Registries and the Applicability of Human Tissue Studies to In-Vivo Counting and Calibration" to the DOE Lung Intercalibration Committee in Richland, WA, May 4, 1995.

- R.L. Kathren presented "Primeval X-ray Protection" to the Conference of Radiation Control Program Directors in San Antonio, Texas, May 8, 1995.

\section{June}

- A.C. James presented "An Update of the NRC's (1991) Dosimetry Study Based on ICRP Publication 66 Recommendations" to the BEIR VI Committee of the National Research Council's Mini-Workshop on Radon and Thoron in the Lung: Comparative" in Montreal, Canada, June 4, 1995.

July

- R.L. Kathren, J.J. Russell, and A.C. James presented "Preliminary Evaluation of the Distribution and Biokinetics of 238Pu in a Whole Body Donor to the USTUR" at the 40th Annual Health Physics Society Meeting in Boston, MA, July 23-27, 1995.

- R.L. Kathren presented "Pathway to a Paradigm: The Linear Nonthreshold Dose Response Model in Historical Context" at the 40th Annual Health Physics Society Meeting in Boston, MA, July 23-27, 1995.

- E.T. Marshall, R.E. Toohey, J.D. Coissart, and R.L. Kathren presented "Distribution of Uranium in Two Whole Body Donors" at the 40th Annual Health Physics Society Meeting in Boston, MA, July 23-27, 1995. 
USTUR Publications and Presentations

October 1, 1994 to September 30, 1995

(cont'd)

August

- R.L. Kathren presented "X-rays and X-ray Protection: Looking Backward Over a Century of Progress for the Benefit of Mankind" at the Hong Kong Radiological Technologists' Association in Hong Kong, August 13, 1995.

- R.L. Kathren presented "The United States Transuranium and Uranium Registries" to the Laboratory of Industrial Hygiene, Ministry of Health, in Beijing, People's Republic of China, August 15, 1995.

- R.L. Kathren presented "X-rays and X-ray Protection: Looking Backward Over a Century of Progress for the Benefit of Mankind" at the Hong Kong University of Science and Technology in Hong Kong, August 18, 1995.

\section{September}

- S. Bao presented "Induction of Micronuclei Following Exposure to ${ }^{60} \mathrm{Co}$ Gamma Rays in the Respiratory Tract" at the 12th Annual Pacific Northwest Association of Toxicologists Meeting in Moscow, D.

- S. Bao presented "Use of Cellular Damage to Determine the Relationship between Exposure and Dose from Inhaled Radon" at the 12th Annual Pacific Northwest Association of Toxicologists Meeting in Moscow, ID.

\section{Awards}

1. R.L. Kathren was the recipient of the 1994 Herbert M. Parker Award of the Columbia Chapter of the Health Physics Society.

2. R.L. Kathren was the recipient of the Hartman Medal of the Radiology Centennial. 


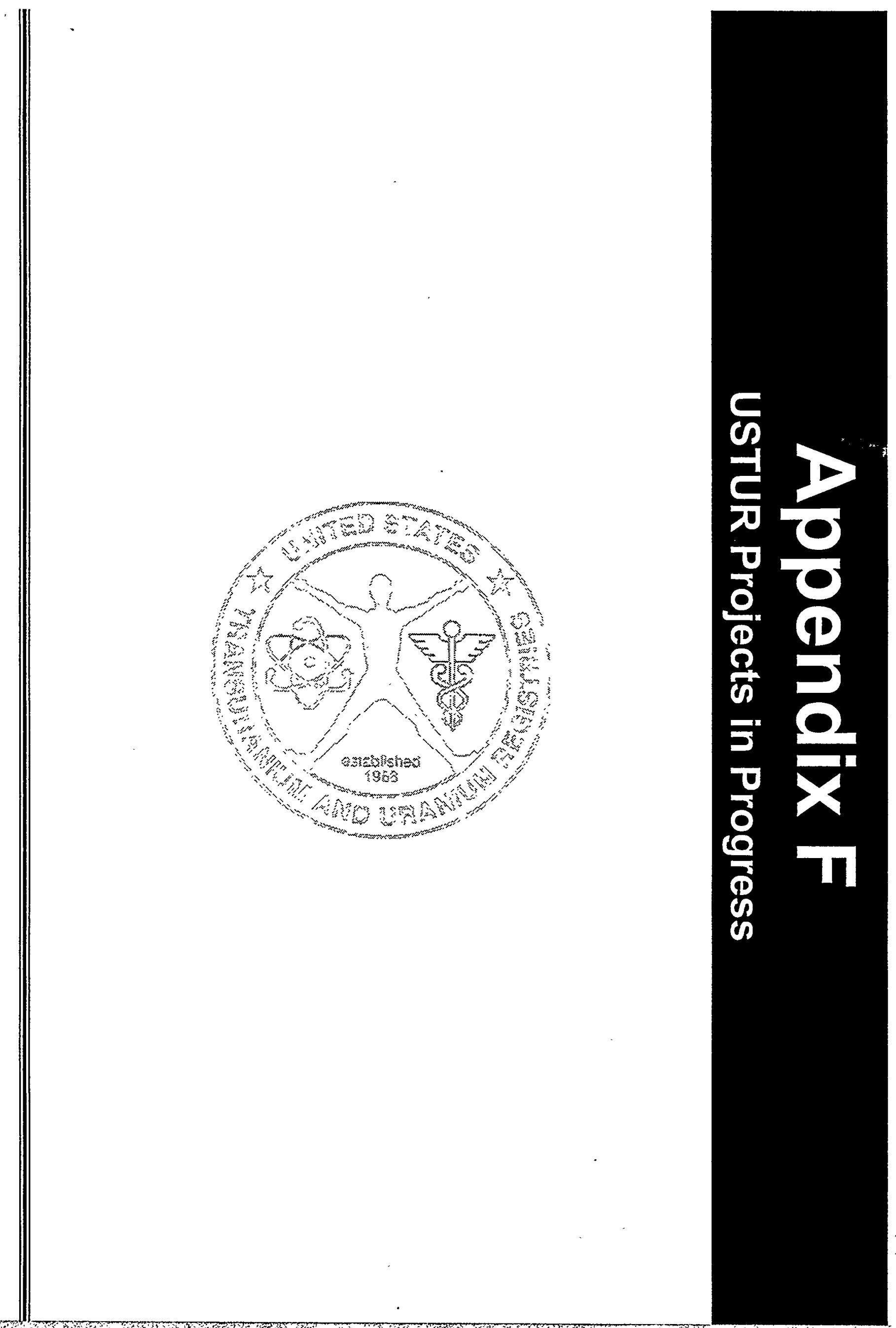




\begin{tabular}{|c|c|c|c|c|}
\hline Title/Description & $\begin{array}{l}\text { *USTUR } \\
\text { Lead }\end{array}$ & $\begin{array}{l}\text { *USTUR } \\
\text { Other }\end{array}$ & $\begin{array}{c}\text { Other } \\
\text { Collaborator(s) }\end{array}$ & $\begin{array}{c}\text { Projected } \\
\text { Completion }\end{array}$ \\
\hline $\begin{array}{l}\text { Biodosimetry Study: } \\
\text { Chromosome aberrations and micronucleus assays are used to detect radiation dam- } \\
\text { age in living registrants and these techniques are being developed. The blood lympho- } \\
\text { cytes from registrants will be used to produce cultures, and the cytogenetic damage } \\
\text { will be linked to biological effective doses from past radiation exposures. }\end{array}$ & SPB & RLK & A. Brooks, PNNL & ongoing \\
\hline
\end{tabular}

\section{Cytogenetic Instability:}

SPB

A. Brooks, PNNL ongoing

Epithelial cells from the rat respiratory tract were cultured after low-LET and highLET radiation. Micronucleus assays were used to study cytogenetic instability. The experiment is partially completed and the papers are being prepared.

\section{Radon Study:}

The radon exposure and biological effective dose to respiratory tract epithelial cells from nose, trachea, and deep lung were investigated. The epithelial cell culture techniques were developed.

\section{USTUR \\ Research and Development} Intemational Atomic Energy Asency

PNNL Pacific Nontwest National Lab

Development of extraction chromatography method for actinides in bone:

Current ion-exchange methods for actinides generate some organic mixed waste and also generate large amounts of chemical waste. Extraction chromatography methods are being developed for the actinides using combinations of EICHROM TRU, TEVA and U-TEVA resins.

Development of extraction chromatography method for actinides in soft

tissues:

Current ion-exchange methods for actinides generate some organic mixed waste and also generate large amounts of chemical waste. Extraction chromatography methods are being developed for the actinides using combinations of EICHROM TRU, TEVA and U-TEVA resins.

Characterization of EICHROM actinide resin for pre-concentration of actinides

RHF

HQ

$6 / 1 / 96$

in tissues:

A. Brooks, PNNL

ongoing

The advantages and disadvantages of using the new ACTINIDE resin for preconcentration of actinides from solution is being investigated. 


\section{USTUR \\ Research and Development Projects}

\begin{tabular}{|c|c|c|c|c|}
\hline Title/Description & $\begin{array}{l}\text { *USTUR } \\
\text { Lead }\end{array}$ & $\begin{array}{l}\text { *USTUR } \\
\text { Other }\end{array}$ & $\begin{array}{c}\text { Other } \\
\text { Collaborator(s) }\end{array}$ & $\begin{array}{c}\text { Projected } \\
\text { Completion }\end{array}$ \\
\hline CP Method for $\mathrm{Ca}$ and $\mathrm{P}$ in bone for normalization of actinide concentrat & RHF & & M. Billings, WSU & $3 / 1 / 96$ \\
\hline
\end{tabular}

An ICP method for actinides in soft tissues: Current ion-exchange methods for actinides generate some organic mixed waste and also generate large amounts of chemical waste. Extraction chromatography methods arebeing developed for the actinides using combinations of EICHROM TRU, TEVA and U-TEVA resins.

Determination of ${ }^{239} \mathrm{Pu}$ in very low level samples by fission-track analysis (FTA):

RHF CLL

An FTA method has been developed for measurement of levels of ${ }^{239} \mathrm{Pu}$ below those currently achieved by alpha spectrometry $(0.02 \mathrm{pCi})$.

Measurement of ${ }^{239+240} \mathrm{Pu}$ ratios in tissues by combined spectroscopy and FTA:

RHF

CLL

$6 / 1 / 96$

A method is being developed to determine total ${ }^{239+240} \mathrm{Pu}$ by alpha spectrometry on vana-

dium disks followed by FTA determination of ${ }^{239} \mathrm{Pu}$ on the disk - thus giving ${ }^{239+240} \mathrm{Pu}$ ratio.

\section{Determination of actinides in NIST bone SRM:}

Methods are being developed for analysis of the new NIST bone SRM.

\begin{tabular}{lll} 
RHF & $\begin{array}{l}\text { SEG, } \\
\text { DBS }\end{array}$ & $6 / 1 / 96$ \\
\hline \multirow{2}{*}{ SEG } & $\begin{array}{l}\text { RHF, } \\
\text { RLK }\end{array}$ & 1998 \\
&
\end{tabular}

Trace metal distribution in human tissues:

Development of methods for determination of Thorium and other trace elements in whole body tissue.

Thorium electrodeposition development:

Difficulties completed were experienced with the electrodeposition method used for $\mathrm{Pu}$

and Am. Modifications were made to improve efficiency and spectral resolution.

\section{Trace element determination in human tissues:}

The USTUR whole-body cases represent aunique opportunity to determine toxic metals in addition to radionuclides. An analytical method involving a combination of neutron activation analysis and ICP-AES is being developed for the determination of trace metals in solutions of tissues from whole body cases already analyzed for actinides.

Development of improved electrodeposition methods for $\mathrm{Pu}, \mathrm{Am}, \mathrm{U}$ :

SEG RHF,
RLK

A program was begun to improve the current electrodeposition methods for $\mathrm{Pu}, \mathrm{Am}, \mathrm{U}$, and $\mathrm{Th}$, primarily to improve the efficiency, resolution and speed of analysis. 


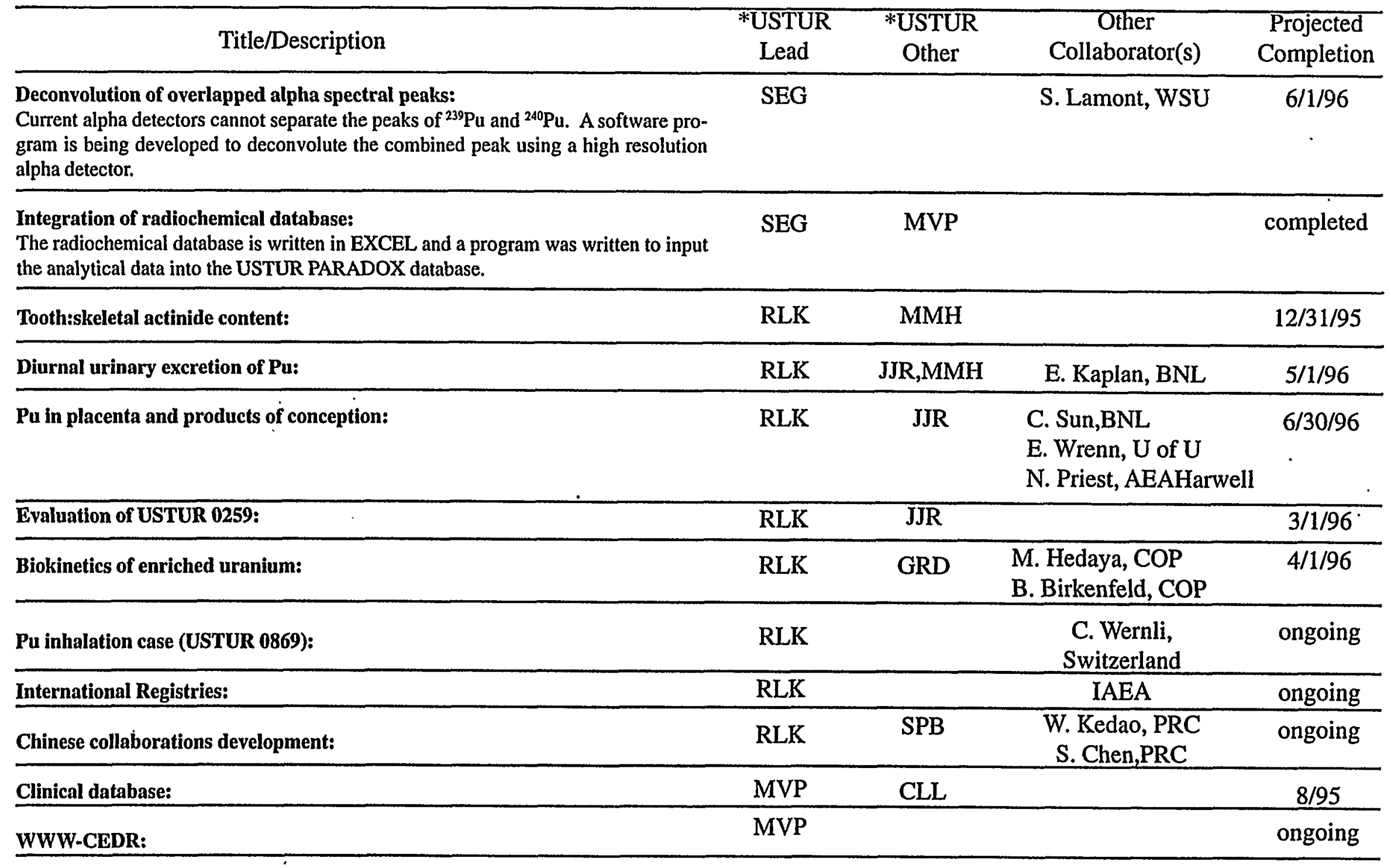

\section{Research and Development}

Projects

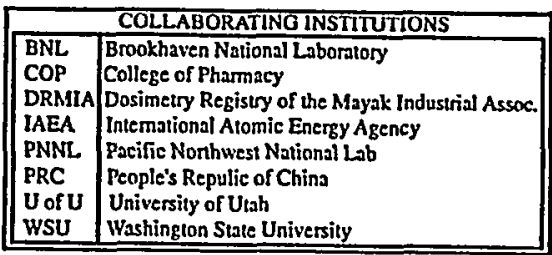

gram is being developed to deconvolute the combined peak using a high resolution alpha detector 


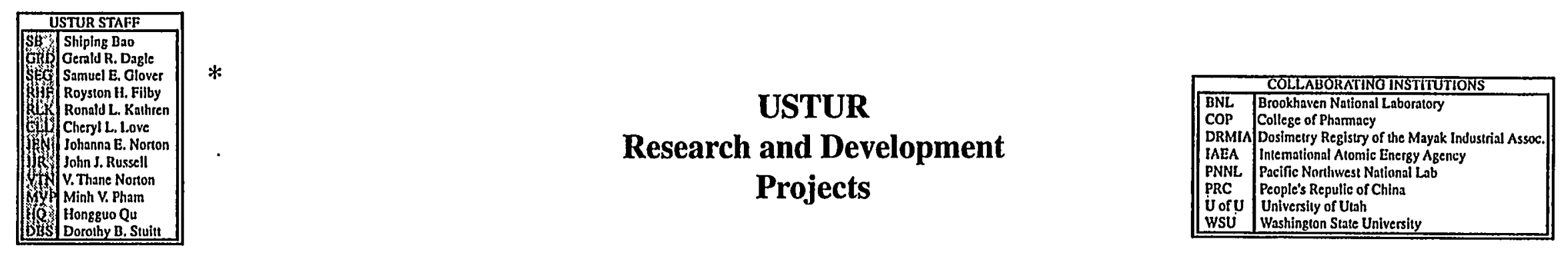

\begin{tabular}{llll}
\hline \multicolumn{1}{c}{ Title/Description } & *USTUR & *USTUR & Other \\
Lead & Other & Projected \\
Collaborator(s) & Completion \\
\hline $\begin{array}{l}\text { Development of a Method for the Determination completed of Th isotopes: } \\
\text { An ion exchange method was developed for }{ }^{228+232} \text { Th determination in tissues. Procedures }\end{array}$ & DBS & HQ &
\end{tabular}

An ion exchange method was developed for ${ }^{228+232} \mathrm{Th}$ determination in tissues. Procedures

from case 0841 .

Finalization of USTUR radiochemistry procedures:

$\begin{array}{lll}\text { DBS } & \text { SEG } & \text { completed } \\ & \text { RHF }\end{array}$

Procedures for $\mathrm{Pu}, \mathrm{Am}, \mathrm{U}$, and $\mathrm{Th}$ werefinalized and the procedures written up in the

Procedures Manual.

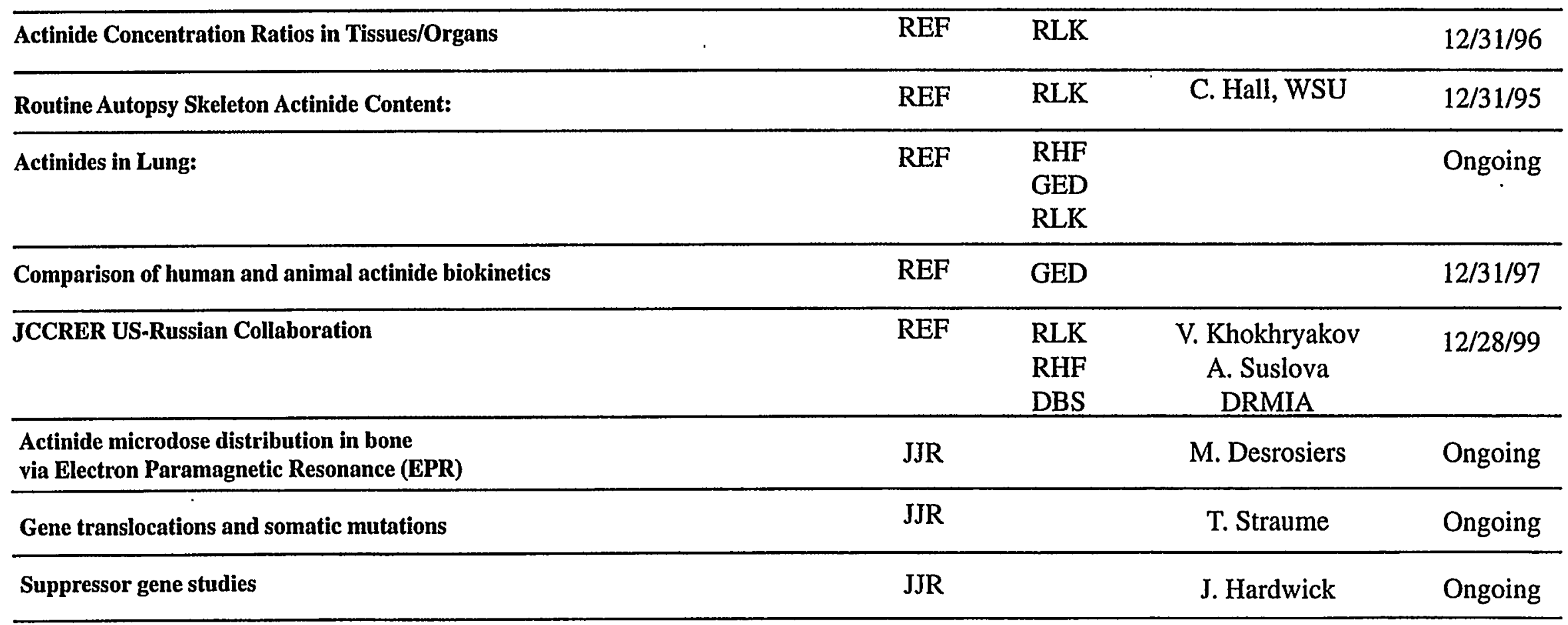



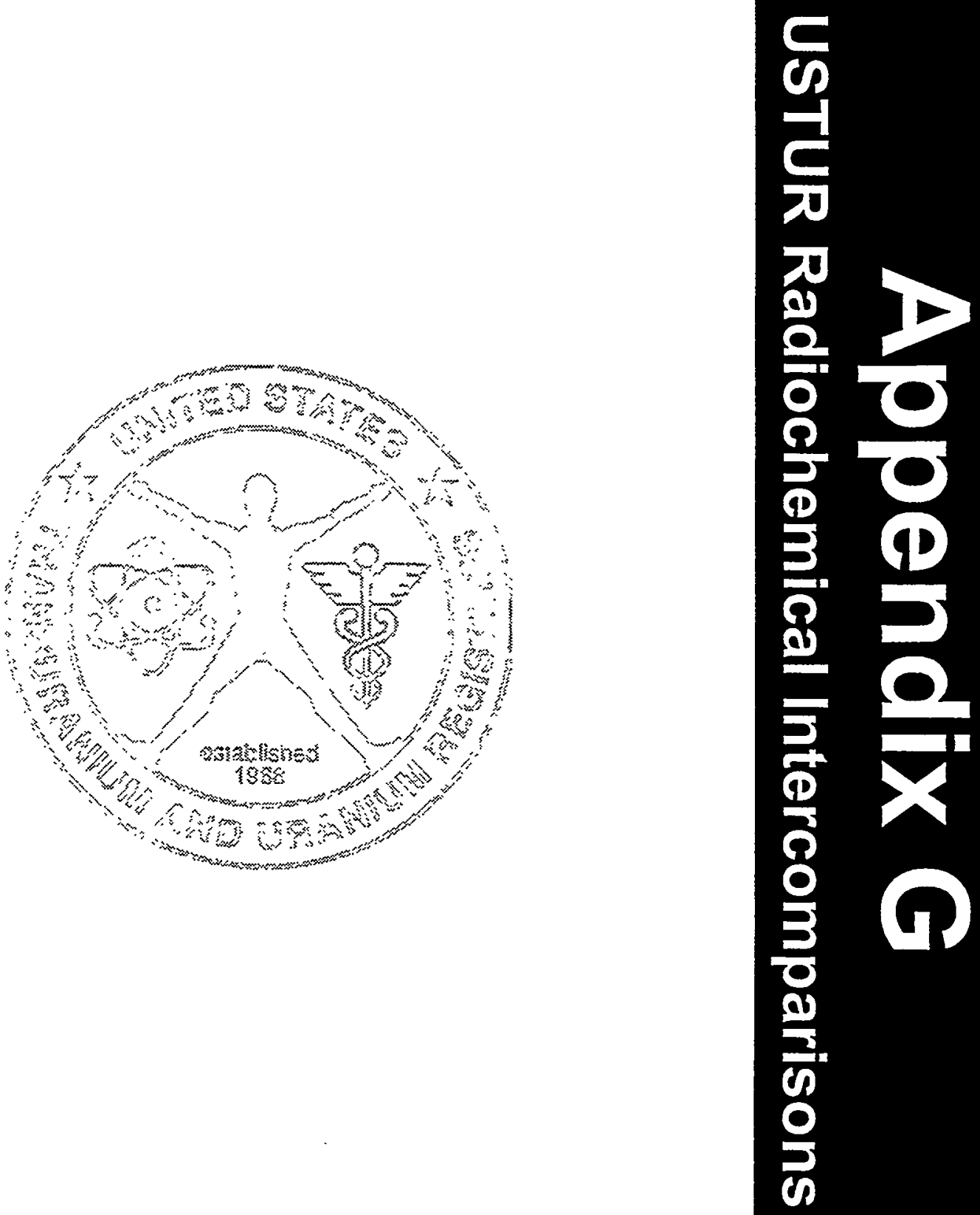


\title{
USTUR RADIOCHEMISTRY REPORT
}

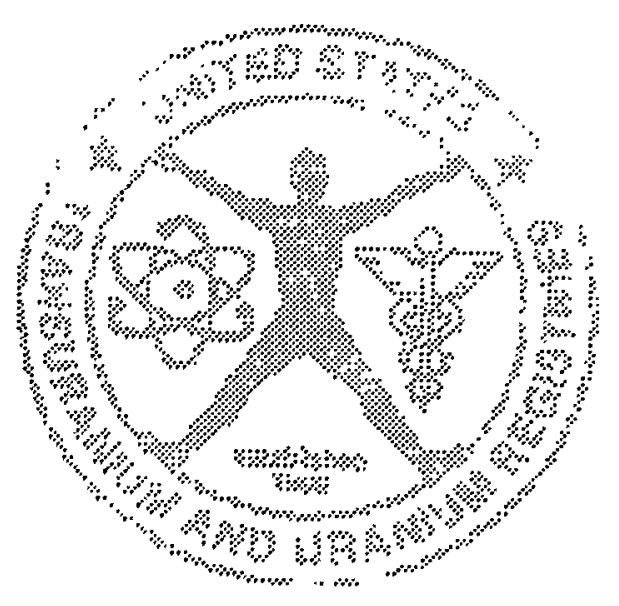

\section{Radiochemical Intercomparisons}

\section{Evaluation of the Results for Intercomparisons 2, 3, 4}

\author{
Presented at the \\ USTUR Advisory Committee Meeting
}

October 17-18, 1995 
This report describes a series of three radiochemistry intercomparisons which were conducted during 1995. These were preceded by the first intercomparison which was conducted in the Fall of 1994 for the . evaluation of alpha spectrometric methods and the results were reported in the 1994 USTUR Annual Report. These intercomparisons are necessary to insure and validate the transition of radiochemical measurements from Los Alamos National Laboratory (LANL) to the United States Transuranium and Uranium Registries located at Washington State University in Pullman (WSU) as well as to evaluate the capabilities of the University of Washington (UW) laboratory which will serve the USTUR radiochemistry program in a QA/QC capacity.

WSU and UW participated in Intercomparison 2 which involved the analysis of 5 blind samples prepared by the other laboratory with contaminant free ${ }^{241} \mathrm{Am}$ and ${ }^{239} \mathrm{Pu}$ traceable to NIST in $8 \mathrm{M} \mathrm{HCl}$. The activity range for these samples was requested to be within 0 to $10 \mathrm{dpm}$.

Intercomparison 3 was conducted using measurements of $8 \mathrm{M} \mathrm{HCl}$ sample solutions prepared by LANL from two USTUR cases, 0637 and 0246 . The original values from LANL were used as the 'known' value for the radiochemical sample activity for comparison of the results for WSU and UW. This intercomparison was designed to evaluate the radiochemical separation methods of the various laboratories with real samples.

Intercomparison 4 presents the results from the anaiysis of NIST lung (SRM 4351) and liver (SRM 4352) standard reference materials (SRM's) for various actinide elements by WSU. This study was chosen in order to evaluate the entire sample analysis program at WSU for selected actinide elements.

WSU adopted procedures very similar to those reported by LANL for the radiochemical analysis of tissues as described in the United States Transuranium and Uranium Registries Radiochemical Analysis Procedures Manual, first edition. This was done in order to expedite the transition of radiochemical analysis form LANL to WSU and in keeping with the recommendations of the 1994 USTUR Advisory Committee. Details of the procedures, calculation of activity, uncertainty, and detection limits are given in the USTUR Radiochemical Analysis Procedures Manual.

The procedures used by LANL for the determination of $\mathrm{Pu}$ and $\mathrm{Am}$ in Intercomparison 3 are those reported in the Radiotissue Chemistry Section of their procedures manual, Health and Environmental Chemistry: Analytical Techniques, Data Management, and Quality Assurance (LA-10300-M). The methods were modified for case 0246 because of the very high ${ }^{241} \mathrm{Am}$ content in the registrants' tissues. These methods were discussed in a recent edition of Health Physics (September 1995) and were based on liquid scintillation counting.

The procedures used by UW for the radiochemical analysis and error propagation are attached in Appendix A. Detection limits provided by UW were calculated based on two times the value of the blank. 


\section{Results forlntercompanson 2}

WSU and UW participated in Intercomparison 2. This intercomparison involved the exchange and analysis of 5 samples spiked with tracer free ${ }^{241} \mathrm{Am}$ and ${ }^{239} \mathrm{Pu}$ traceable to NIST in $8 \mathrm{M} \mathrm{HCl}$. Each laboratory prepared the samples with their own isotopic spikes and provided the solutions to the other . laboratory with the content unknown. The activity range for these samples was requested to be within 0 to $10 \mathrm{dpm}$. Each laboratory then analyzed the samples according to their procedures and reported the sample activity and its associated uncertainty. The results for this intercomparison are presented on the following two pages.

The intercomparison data were analyzed in a fashion similar to that described by ANSI N13.30. The relative percent bias from the 'known' activity for each sample is defined for a given laboratory as:

$\%$ Bias for a given isotope for each sample $=B_{n}(\%)=\left(\frac{A_{a i}-A_{i}}{A_{i}}\right) \times 100$

$A_{a i}=$ The measurement for a given isotope a for sample number $i$ for a given laboratory. $A_{i}=$ The 'known' isotopic value for sample number $i$.

The relative bias for each isotope is then defined for a given laboratory for each isotope as:

$$
\text { Relative laboratory bias }(\%)=B_{r}(\%)=\bar{B}_{n i}=\frac{\sum_{i=1}^{N} B_{n}}{N}
$$

Where $\mathrm{N}$ is the number of samples values reported for a particular isotope for a given laboratory. The relative laboratory bias (\%)was calculated using all reported values for each isotope, excluding those below the Minimum Testing Level (MTL). For the purposes of this intercomparison, only samples to which no activity was added were below the MTL. All other samples were well above the detection limits for that laboratory.

The relative bias precision for each isotope for a given laboratory (e.g. the WSU bias in box in the following table) is defined as:

$$
\text { Precision }=S_{B}(\%)=\sqrt{\sum \frac{\left(B_{n i}-B_{r}\right)^{2}}{(N-1)}}
$$

The results of WSU for the spiked solutions prepared by $U W$ for both ${ }^{239} \mathrm{Pu}$ and ${ }^{241} \mathrm{Am}$ are in good agreement with the spiked values reported by UW. Sample X04 leaked slightly during transportation to WSU but was not excluded from this data set for the purposes of calculating bias or precision. WSU correctly identified samples which had no activity added as below the detection limit.

The results for UW for the spiked solutions prepared by WSU are also generally in agreement with the spiked values reported by WSU. Sample QA2 did show high bias for both ${ }^{239} \mathrm{Pu}$ and ${ }^{241} \mathrm{Am}$. UW correctly identified that there was no ${ }^{239} \mathrm{Pu}$ activity exceeding the limit of detection in sample QA1, however misreported the presence of ${ }^{241} \mathrm{Am}$ in that same sample. UW defined the detection limit as :

$L D$ for ${ }^{239.240} \mathrm{Pu}=2 \times$ blank value $=2 \times .0 .011 \mathrm{dpm}=0.022 \mathrm{dpm}(3.7 \times 10-4 \mathrm{~Bq})$

$L D$ for ${ }^{24 l} \mathrm{Am}=2 \times$ blank value $=2 \times 0.009 \mathrm{dpm}=0.018 \mathrm{dpm}(3.0 \times 10-4 \mathrm{~Bq})$. 
Intercomparison 2:

Results for WSU

\begin{tabular}{|c|c|c|c|c|c|c|c|c|c|c|c|}
\hline Sample \# & Sample Description & Pu Sampl & Result (Bo & (Sample) & Am Sampl & e Result $(\mathrm{Bg}$ & (Sample) & WS & Bias & & ঝ: : : : \\
\hline 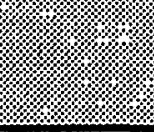 & & $\begin{array}{c}\text { Spike Value } \\
\text { Pu-239 }\end{array}$ & $\begin{array}{l}\text { WSU } \\
\text { Pu-239 }\end{array}$ & \pm 1 sigma & $\begin{array}{c}\text { Spike Value } \\
\text { Am-241 }\end{array}$ & $\begin{array}{c}\text { WSU Am- } \\
241\end{array}$ & \pm 1 sigma & Pu-239 & Am-241 & $\begin{array}{c}\text { WSU' } \\
\text { Pu-239 } \\
\text { Notes }\end{array}$ & $\begin{array}{c}\text { WSU } \\
\text { Am-241 } \\
\text { Notes }\end{array}$ \\
\hline $\mathrm{X} 01$ & QAVQC SAMPLE \#1 & $0.000 \mathrm{E}+00$ & $2.97 \mathrm{E}-04$ & $4.06 \mathrm{E}-04$ & $1.580 \mathrm{E}-01$ & $1.66 \mathrm{E}-01$ & $5.09 \mathrm{E}-03$ & & 5,06 & $<\mathrm{Ld}$ & \\
\hline $\mathrm{X} 02$ & QAVOC SAMPLE \#2 & $4.810 \mathrm{E}-02$ & $4.15 \mathrm{E}-02$ & $2.53 \mathrm{E}-03$ & $1.380 \mathrm{E}-01$ & $1.46 \mathrm{E}-01$ & $4.87 \mathrm{E}-03$ & -13.72 & 5.80 & & \\
\hline $\mathrm{X} 03$ & QA/QC SAMPLE \#3 & $7.210 \mathrm{E}-02$ & $6.78 \mathrm{E}-02$ & $3.31 \mathrm{E}-03$ & $7.910 \mathrm{E}-02$ & $8.13 \mathrm{E}-02$ & $3.86 \mathrm{E}-03$ & -5.96 & 2.78 & & \\
\hline X04 & QAVQC SAMPLE \#4 & $1.200 \mathrm{E}-01$ & $1.27 \mathrm{E}-01$ & $4.70 \mathrm{E}-03$ & $3.950 \mathrm{E}-02$ & $4.07 \mathrm{E}-02$ & $2.58 \mathrm{E}-03$ & 5.83 & 3.04 & & \\
\hline $\mathrm{X05}$ & QAOC SAMPLE \#5 & $1.680 \mathrm{E}-01$ & $1.76 \mathrm{E}-01$ & $5.05 \mathrm{E}-03$ & $0.000 \mathrm{E}+00$ & $-1.31 \mathrm{E}-04$ & $6.04 \mathrm{E}-04$ & 4.76 & & & $<\mathrm{Ld}$ \\
\hline $\begin{array}{l}\text { NOTES: } \\
\text { Spiked solv }\end{array}$ & ns prepared by UW & & & & & & & & & & \\
\hline & & & & Pu-239 & Am-241 & & & & & & \\
\hline & & WSU Bias ( & & -2.27 & 4.17 & & & & & & \\
\hline & & WSU Precisi & on $(\%)$ & 9.31 & 1.49 & & & & & & \\
\hline & & & & & & & & & & & \\
\hline
\end{tabular}




\section{Intercomparison 2:}

Results for UW

\begin{tabular}{|c|c|c|c|c|c|c|c|c|c|c|c|c|}
\hline$\frac{\text { Sample H }}{\%}$ & Sample Description & & Sample Res & ult (Bq/Sam & ple) & Am Sam & le Result (B & g/Sample) & UW $\%$ & Bias & \%ิ & $\%$ \\
\hline 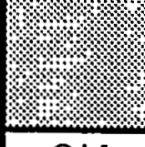 & & $\begin{array}{l}\text { Spike Value } \\
\text { Pu-239/240 }\end{array}$ & $\begin{array}{c}\mathrm{UW} \\
\mathrm{Pu}-239 / 240\end{array}$ & \pm 1 sigma & $\begin{array}{l}\text { Sample Ce } \\
\text { (Bq/sample) }\end{array}$ & $\begin{array}{c}\text { Spike } \\
\text { Value Am- } \\
241 \text { (a) }\end{array}$ & $\begin{array}{c}\text { UW } \\
\text { Am-241 }\end{array}$ & \pm 1 sigma & $\mathrm{Pu}-239 / 240$ & Am-241 & $\begin{array}{c}\text { UW } \\
\text { Pu-239/240 } \\
\text { Notes }\end{array}$ & $\begin{array}{c}\text { UW } \\
\text { Am-241 } \\
\text { Notes }\end{array}$ \\
\hline QA1 & QA/QC SAMPLE \#1 & $0.000 \mathrm{E}+00$ & 7.357E-04 & $4.554 \mathrm{E}-04$ & 7.707E-04 & $0.000 \mathrm{E}+00$ & $4.169 \mathrm{E}_{-} 03$ & $1.534 \mathrm{E}-03$ & & & $<\mathrm{Ld}$ & $>$ Ld \\
\hline QA2 & QA/QC SAMPLE \#2 & $3.825 \mathrm{E}-02$ & $4.483 \mathrm{E}-02$ & 2.619E-03 & $7.387 \mathrm{E}-04$ & 3.753E-02 & $4.892 \mathrm{E}-02$ & $2.821 \mathrm{E}-03$ & 17.19 & 30.36 & & \\
\hline QA3 & QA/QC SAMPLE \#3 & 1.913E-01 & 1.761E-01 & 7.042E-03 & $7.239 \mathrm{E}-04$ & $3.670 \mathrm{E}-02$ & $3.798 \mathrm{E}-02$ & $2.226 \mathrm{E}-03$ & -7.96 & 3.50 & & \\
\hline QA4 & QA/QC SAMPLE \#4 & 1.913E-01 & $1.948 \mathrm{E}-01$ & $7.786 \mathrm{E}-03$ & $7.415 \mathrm{E}-04$ & $1.876 \mathrm{E}-01$ & $1.902 \mathrm{E}-01$ & $7.684 \mathrm{E}-03$ & 1.83 & 1.40 & & \\
\hline QA5 & QA/OC SAMPLE H5 & 3.825E-02 & $3.901 E-02$ & 2.299E-03 & $7.436 \mathrm{E}-04$ & $1.866 \mathrm{E}-01$ & $1.923 \mathrm{E}-01$ & 7.707E-03 & 1.98 & 3.09 & & \\
\hline $\begin{array}{l}\text { Notess } \\
\text { Spiked sol }\end{array}$ & $\begin{array}{l}\text { \% } \text { ons prepared by WSU. } \\
\text { la }\end{array}$ & & & & & & & & & & & \\
\hline$\frac{\text { Am-241 in }}{\text { (a) Correc }}$ & $\begin{array}{l}\text { recly identified as bein } \\
\text { for Am-241 content o }\end{array}$ & $\frac{\text { as present in }}{\mathrm{Pu}-239 / 240 \mathrm{sp}}$ & $\frac{\text { QAl }}{\text { pike }}$ & & & & & & & & & \\
\hline & & & $\%$ & $\mathrm{Pu}-239 / 240$ & $A m-241$ & & & & & & & \\
\hline & & UW Bias (\%) & & 3.26 & 9.59 & & & & & & & \\
\hline & & UW Precision & $n(\%)^{*}$ & 10.39 & 13.88 & & & & & & & \\
\hline & ঝ. & 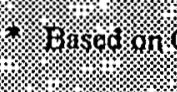 & $6 \%$ & itis. & $\%$ & & & & & & & \\
\hline
\end{tabular}




\section{Results for intercompanson 3}

Intercomparison 3 was conducted among WSU, LANL, and UW. This intercomparison was conducted using samples from two USTUR cases which had been previously analyzed by LANL, 0637 and 0246 . Case 0637 was analyzed by the USTUR and UW for ${ }^{238} \mathrm{Pu}$ and ${ }^{239 / 240} \mathrm{Pu}$ content, while case 0246 was analyzed for ${ }^{241} \mathrm{Am}$. USTUR Case Number 0637 corresponds to LANL Number 56-068 while USTUR Case Number 0246 is 47-058.

The samples for both of these cases had been prepared by LANL several years previously and were recently transferred from LANL to WSU at Pullman. These samples were assigned a USTUR sample number using current procedures. Samples were picked for the USTUR, LANL, and UW intercomparison to provide a range of activity values and sample compositions. A further sample selection criterion included how much sample remained for the intercomparison. LANL often used one-half of the sample for routine analysis and thus the intercomparison was sample limited which restricted many of the samples to a two-way intercomparison (LANL-WSU). Seven samples from Case 0637 and five samples from Case 0246 were chosen for the three way intercomparison. All samples from case 0637 were processed by WSU ( 22 in total) including 0637016 , thyroid, which had not been processed by LANL.

The LANL Case 0637 data used for this intercomparison was provided by personal with Jim McInroy (Case 0637 was in final reporting status and thus the data was not available at the USTUR-TriCities). The data for Case 0246 were derived from the USTUR database and LANL laboratory notebooks. Many of these data appeared without uncertainty information and as such these uncertainty values could not be included for evaluation. Furthermore, the standard methods used by LANL had been modified for the analysis of Case 0246 to utilize liquid scintillation counting at LANL because of the very high tissue content of ${ }^{241} \mathrm{Am}$.

The WSU data represent the values obtained by a single alpha spectrometric radiochemical determination with its associated uncertainty. The UW repeated the analysis of the samples and reported the data as the average of the two determinations and used the average of the uncertainty values.

Samples for three way intercomparison are described in the following table. 
USTUR, LANL, UW Intercomparison

\begin{tabular}{|c|c|c|c|c|c|c|}
\hline \multirow{2}{*}{$\begin{array}{l}\text { Sample } \\
\text { Number. }\end{array}$} & \multirow{2}{*}{$\begin{array}{c}\text { Sample } \\
\text { Description }\end{array}$} & \multicolumn{2}{|c|}{ Elements For Analysis } & \multirow{2}{*}{$\begin{array}{c}\text { Initial Total } \\
\text { Solution } \\
\text { Weight } \\
\text { (g) } \\
\end{array}$} & \multirow{2}{*}{$\begin{array}{c}\text { Total } \\
\text { Solution } \\
\text { Provided to } \\
\text { UW } \\
\text { (g) } \\
\end{array}$} & \multirow{2}{*}{$\begin{array}{c}\text { Estimated } \\
\text { Aliquot } \\
\text { Activity } \\
\text { Range } \\
\\
\end{array}$} \\
\hline & & $\mathbf{P u}$ & Am & & & \\
\hline 0637001 & Liver & $x$ & & 500.0 & 100.0 & Medium \\
\hline 0637002 & Lung-R & $x$ & & 400.0 & 80.0 & Medium \\
\hline 0637009 & Pericardium & $\bar{x}$ & & 400.0 & 100.0 & Low \\
\hline 0637010 & Aortic Arch & $\mathbf{x}$ & & 300.0 & 60.0 & Low \\
\hline 0637017 & Vertebrae & $\mathbf{x}$ & & 700.0 & 100.0 & Very Low \\
\hline 0637018 & Rib & $x$ & & 800.0 & 200.0 & Very Low \\
\hline 0637021 & Patella-R & $x$ & & 200.1 & 48.3 & Low \\
\hline 0246001 & Liver \#1 & & $x$ & 100.0 & 2.18 & Very High \\
\hline 0246002 & L. Lung LI & & $x$ & 105.0 & 5.03 & High \\
\hline 0246003 & Spleen & & $x$ & 100.0 & 5.03 & Medium \\
\hline 0246004 & $\begin{array}{l}\text { Rectus } \\
\text { Muscle }\end{array}$ & & $x$ & 100.0 & 5.24 & Medium \\
\hline 0246005 & $\begin{array}{c}\text { Clavicle } \\
\text { Acro. } \\
\text { Marrow }\end{array}$ & & $x$ & 800.1 & 10.03 & Low \\
\hline
\end{tabular}

Estimated aliquot activity range based on using one-half of the total solution provided to $U W$. The following definitions apply:

Very Low $\equiv$ Aliquot Activity (dpm) $<1$

Low $\equiv 1<$ Aliquot Activity (dpm) $<10$

Medium $\equiv 10<$ Aliquot Activity (dpm) $<100$

High $\equiv 100<$ Aliquot Activity (dpm) $<1000$

Very High $\equiv 1000<$ Aliquot Activity (dpm) $<2000$ 
The results from this intercomparison were again analyzed in a fashion similar to that described in ANSI N.13 30 using the following statistics:

- Relative bias from the 'known' activity for each sample for a given laboratory

- Relative bias for the isotope for a given laboratory

- The relative precision of the relative bias for each isotope for a given laboratory

- $t$ value for the difference between the laboratory's value and LANL's value

The relative percent bias from the mean activity for each sample is defined for a given laboratory as:

$$
B_{n}(\%)=\left(\frac{A_{a i}-A_{i}}{A_{i}}\right) \times 100
$$

$A_{a i}=$ The measurement for a given isotope a for sample number i for a given laboratory.

$A_{i} \equiv$ The average value for sample number $i$.

The relative bias for each isotope is defined for a given laboratory as:

$$
B_{r}(\%)=\bar{B}_{n i}=\frac{\sum_{i=1}^{N} B_{n i}}{N}
$$

Where $\mathrm{N}$ is the number of samples values reported for a particular isotope for a given laboratory. $\mathrm{B}_{\mathrm{r}}$ was calculated using all reported values for each isotope, including those below the Minimum Testing Level (MTL).

The radiochemical sample activity as reported by LANL was used as the 'known' activity of the sample. Only the values for samples which had been run by all three labs and were above the MTL were included in the analysis estimation of bias and precision. The MTL for Intercomparison 3 was defined as 5 times the limit of detection as quoted by LANL procedures, 0.06 disintegrations per minute (dpm) for each of the isotopes, times 4 (only one-fourth or less of the sample was available for analysis), divided by 60 $\mathrm{Bq} / \mathrm{dpm}$. This corresponds to a MTL of $0.02 \mathrm{~Bq} / \mathrm{sample}$. This value was used as a reference for all laboratories.

The relative precision for each isotope for a given laboratory is defined as:

$$
S_{B}(\%)=\sqrt{\sum \frac{\left(B_{r i}-B_{r}\right)^{2}}{(N-1)}}
$$

The $t$ value for the difference between the laboratory's value and LANL's was calculated as follows:

$$
t=\frac{\overline{x_{i}}-\overline{x_{L A N L}}}{\left[\frac{s_{i}^{2}}{n_{i}}+\frac{s_{L A N L}^{2}}{n_{L A N L}}\right]^{1 / 2}}
$$

where $n=2$ for $U W$, and 1 for all others. 
The acceptable ranges for relative bias and the relative precision are from $-25 \%$ to $+50 \%$ and 40 , respectively, for those values which are above the laboratory's MTL (ANSI N13.30). The relative bias and the relative precision of the bias were recalculated where possible for each laboratory in each category using only those values for which the average value equaled or exceeded the MTL.

The anaiysis for ${ }^{238} \mathrm{Pu}$ was limited because many of the samples for case 0637 were below the MTL 0.02 . $\mathrm{Bq} / \mathrm{sample)}$. Furthermore, UW did not report the results for 4 of the 7 requested samples for ${ }^{238} \mathrm{Pu}$ because of very high blank values. However, based on these limited results, WSU showed no significant difference from LANL in samples above the MTL. The results for UW for the samples which were reported for ${ }^{238} \mathrm{Pu}$ and above the MTL showed negative bias. This result could be explained by the laboratory's high ${ }^{238} \mathrm{Pu}$ blank values (potentially contamination of some interfering isotope). Due to the limited number of reported analysis not much can be gained from these results.

The analysis of ${ }^{239} \mathrm{Pu}$ in the selected samples for Case 0637 were again limited by the low levels of activity present. UW reported all requested samples. Both laboratories showed excellent agreement for samples above the MTL and for which no problems were reported. Two of the samples chosen had leaked during storage or transportation and are included for review, but are not part of the statistical analysis of bias or precision. These samples also showed generally good agreement between the laboratories and LANL except for 0637021 , the right patella. Both laboratories found the activity of the sample to be $\sim 250 \%$ higher than reported by LANL It should be noted that the LANL value for this sample (right patella) may be in error since the LANL value for the left patella is $5.19 \mathrm{E}-02 \mathrm{~Bq}$, consistent with the UW and WSU results for the right patella, 5.10E-02 and 5.35E-02 Bq respectively, and the WSU result for the left patella of $4.96 \mathrm{E}-02 \mathrm{~Bq}$. Only one other sample showed significant difference from the reported LANL value for WSU and that sample's results are suspect due to leakage of the bottle during storage and due to foreign material in the solution upon inspection prior to analysis. This foreign material was apparently caused by degradation of the lining in the bottle cap.

The analysis of the ${ }^{241} \mathrm{Am}$ data selected from case 0246 showed excellent agreement between the values reported by LANL and the results for WSU. All samples were above the MTL. Only one sample from UW showed significant bias (liver \#1) from the reported LANL value. The bias and precision for both laboratories is good.

There are some other general comments concerning these analysis which need to be stressed. There are some difficulties associated with the analysis of samples which have been in storage for several years. The solution stability of the actinides, even in $8 \mathrm{M} \mathrm{HCl}$, is not proven. Some of the samples showed signs of leakage and in some cases foreign material was present. Given these circumstances, this intercomparison showed reasonable agreement for all laboratories. 
${ }^{238} \mathrm{Pu}$ Results for Intercomparison 3

\begin{tabular}{|c|c|c|c|c|c|c|c|c|c|c|c|c|}
\hline \multirow{2}{*}{ Somple } & \multirow{2}{*}{ Sample Description } & \multicolumn{6}{|c|}{ Pu Sample Result (Bq/ Radiochemical Sampk) } & \multicolumn{2}{|c|}{$\begin{array}{l}\text { Pu-238 \% Difference } \\
\text { (Based on LANL) }\end{array}$} & \multicolumn{2}{|c|}{ Pu-238 \# SD (t value) } & \multirow[b]{2}{*}{ Notes } \\
\hline & & $\begin{array}{l}\text { LANL } \\
\text { Pu-238 }\end{array}$ & \pm 1 sigma & $\begin{array}{l}\text { WSU } \\
\text { Pu-238 }\end{array}$ & \pm 1 sigma & $\begin{array}{l}\text { UW } \\
\text { Pu-238 }\end{array}$ & \pm 1 sigma & wsU & uw & WSU & uw & \\
\hline 0637001 & Liver & $2.607 \mathrm{E}-02$ & 2.347E-03 & $2.764 \mathrm{E}-02$ & $4.360 \mathrm{E} 03$ & $1.417 \mathrm{E}-02$ & $6.667 \mathrm{z}-03$ & $6.0 \%$ & - $45.7 \%$ & ....3........ & -1.7........... & \\
\hline 0637002 & Huns:R & $5.237 \mathrm{E} 02$ & $2.650 \mathrm{E}-03$ & s. 109502. & $1.070 \mathrm{E}-02$ & $4.500 \mathrm{E}-02$ & $1.335 \mathrm{E}-02$ & $-2.4 \%$ & $-14.1 \%$ & -0.1 & -0.5 & \\
\hline 0637003 & Lung-L & $4.370 \mathrm{E}=02$ & $2410 \mathrm{E}-03$ & $5.533 \mathrm{E}-02$ & 4.103503 & & & & & & & \\
\hline 0637004 & TBLN & 4.200003 & 6.033504 & $2.181 \mathrm{E}-03$ & $1.275 \mathrm{E}, 03$ & & & & & & & $\Delta M$ \\
\hline 0637005 & ZN-hilar & $5.667 \mathrm{E} 04$ & 3200504 & $2238 \mathrm{E}-04$ & $4466 \mathrm{E}-04$ & & & & & & & 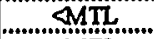 \\
\hline 0637005 & Kidney-R & $2.000 \mathrm{E}_{0} 04$ & $2.367 \mathrm{E} 04$ & $1.233 \mathrm{E}, 04$ & $1.987 \mathrm{E}-04$ & & & & & & & $\triangle M T L$ \\
\hline 0679007 & Kidney.L. & 6.667505 & 1.767004 & $2763 \mathrm{~g}-05$ & $167 ? 0_{0} 04$ & & & & & & & 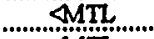 \\
\hline 0637008 & Heart & $3.000 \mathrm{E} 04$ & 2.467504 & $5.155 \mathrm{E}-05$ & $3.527 \mathrm{E}-04$ & \%א & & & & & & $\varangle M \pi$ \\
\hline 0637009 & pericandium & $3.033 \mathrm{E} 003$ & 5300004 & $2381=03$ & 134503 & $4000 \mathrm{E}-03$ & $2000 \mathrm{~B}-03$ & & $3 \%$ & $3 \%$ & 80 & $\triangle M T$ \\
\hline o6s37oio & Aonticarch & 4800003 & 75604 & 46050 & 19.03 & 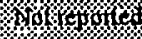 & & & w & & & MnL \\
\hline 0637011 & Spleen & $1.333 \mathrm{E}=04$ & 2367504 & $554 \mathrm{~g} 04$ & 4324504 & & & & & & & ......................... \\
\hline 0637012 & Stomach \& Esoph. & $1.667 \mathrm{E}-04$ & $2.667 \mathrm{k} 04$ & i.2725-03 & $2.297 \mathrm{E} .03$ & & & & & & & $\triangle M T A$ \\
\hline 0637013 & Prostate & -2.00004 & 226604 & $-3.561 \mathrm{E} 05$ & $1.754 \mathrm{E}-04$ & & & & & & & ...MII \\
\hline 0637014 & Testis:R & $0.000 \mathrm{E}+00$ & $8.800 \mathrm{E}, 03$ & 2.675E-0S & $1.730 \mathrm{E}-04$ & & & & & & & $\triangle M T L$ \\
\hline 0637015 & Testis-L & $3.333 \mathrm{E} 0 \mathrm{~S}$ & 2000004 & .98360 .05 & 2005004 & & & & & & & MTL. \\
\hline 0637016 & Thyroid & ঝ & / & $-2450 \mathrm{~g} 04$ & 3.301104 & & & & & & & $4 \pi$ \\
\hline 0637017 & Vertebrae & $1.533 \mathrm{E}_{0} 03$ & $7.133 \mathrm{E}-04$ & 2.291003 & $1.459 \mathrm{E} 03$ & & & & & 6 & & ATR \\
\hline 0637018 & $\mathrm{Rib}$ & $-2.533 \mathrm{E} 03$ & 26003 & 1.585003 & 7992504 & \%or. & & & & 聯 & $8 \%$ & STM \\
\hline 0637019 & Stemum & 5.667 .04 & 4267004 & 7.000E-05 & $3.692 \mathrm{E}-04$ & \% & & & w & & 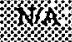 & 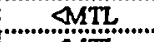 \\
\hline 0637020 & Clavicle & 3000004 & 386004 & -7.699006 & 4011504 & & & & & & & $\triangle M T$ \\
\hline 0637021 & Patella-R & $1.607 \mathrm{E} 04$ & 2433004 & 309004 & 431504 & Xon & & & & 113 & $N$ & AMT \\
\hline 0637022 & Patella-L & $6.667 \mathrm{E}-04$ & $3.600 \mathrm{E}-04$ & $5.778 \mathrm{E}, 04$ & $6.236 \mathrm{E} 04$ & & & & & & & QMTL \\
\hline 0246001 & LiverH1 & & & & & & & & & & & \\
\hline 0246002 & 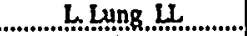 & & & & & & & & & & & \\
\hline 0246003 & Spleen & & & & & & & & & & & \\
\hline 0246004 & Rectus Muscle & & & & & & & & & & & \\
\hline 0246005 & Clavicle Aero. Marrow & & & & & & & & & & & \\
\hline \multirow{2}{*}{\multicolumn{13}{|c|}{ 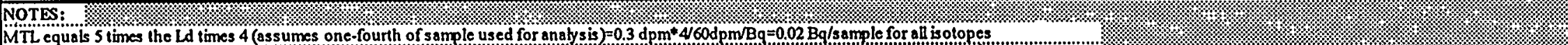 }} \\
\hline \multirow{2}{*}{\multicolumn{13}{|c|}{ 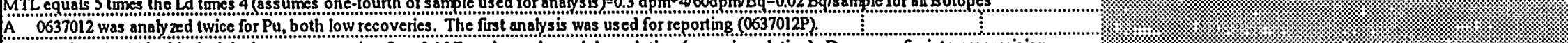 }} \\
\hline & & & & & & & & & & & & \\
\hline \multirow{2}{*}{\multicolumn{13}{|c|}{ 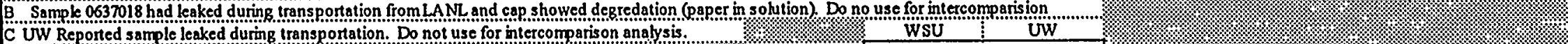 }} \\
\hline & & & & & & & WSU & UW & & & & \\
\hline & & & & & & Bias.(\%).............. & $1.8 \%$ & - & & & & \\
\hline & & & & $6 \%$ & & Precision (\%) & $6.0 \%$ & $22.3 \%$ & & & & \\
\hline & & & & & & 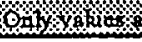 & m & (cistom & & & & \\
\hline
\end{tabular}




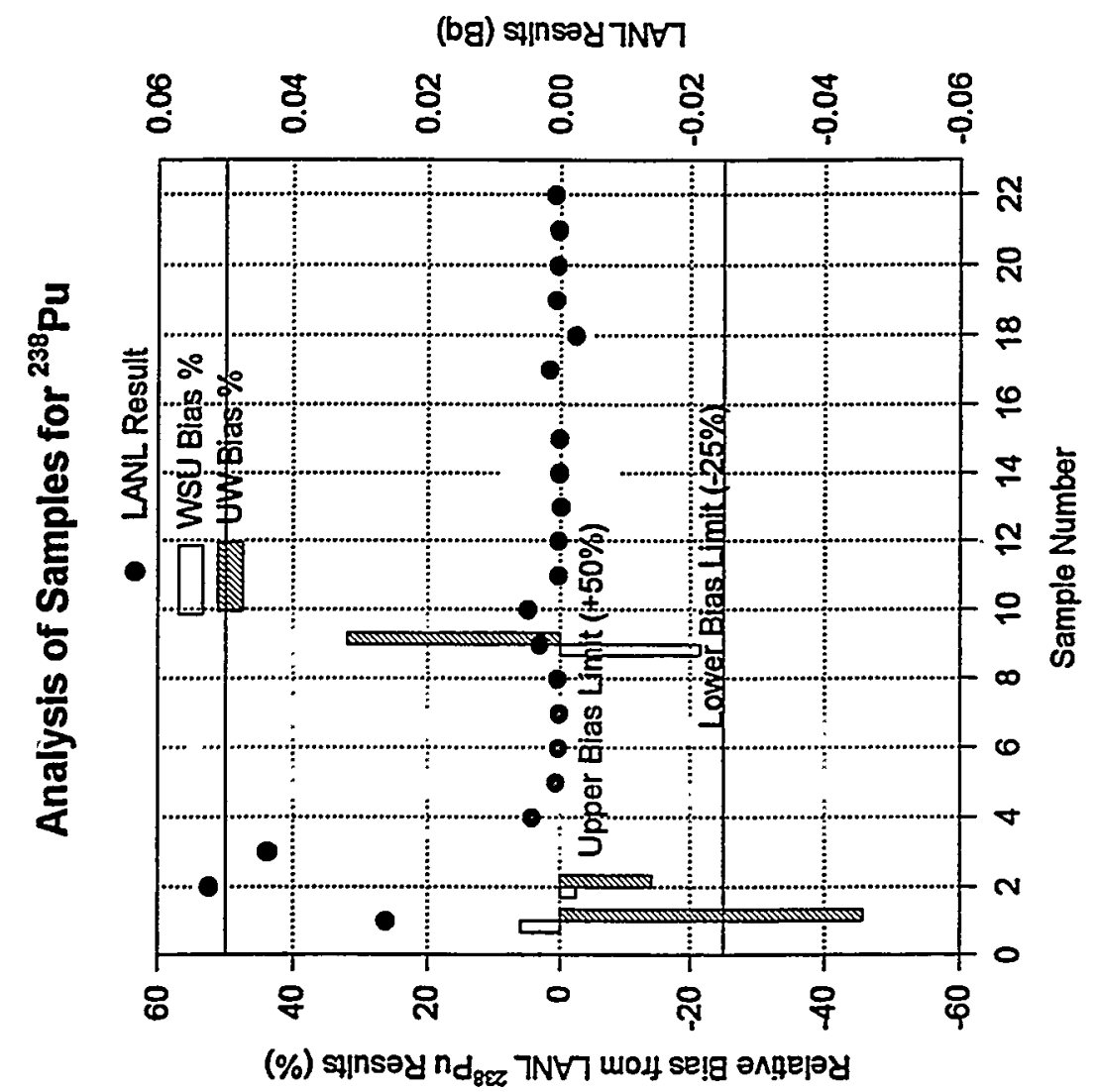




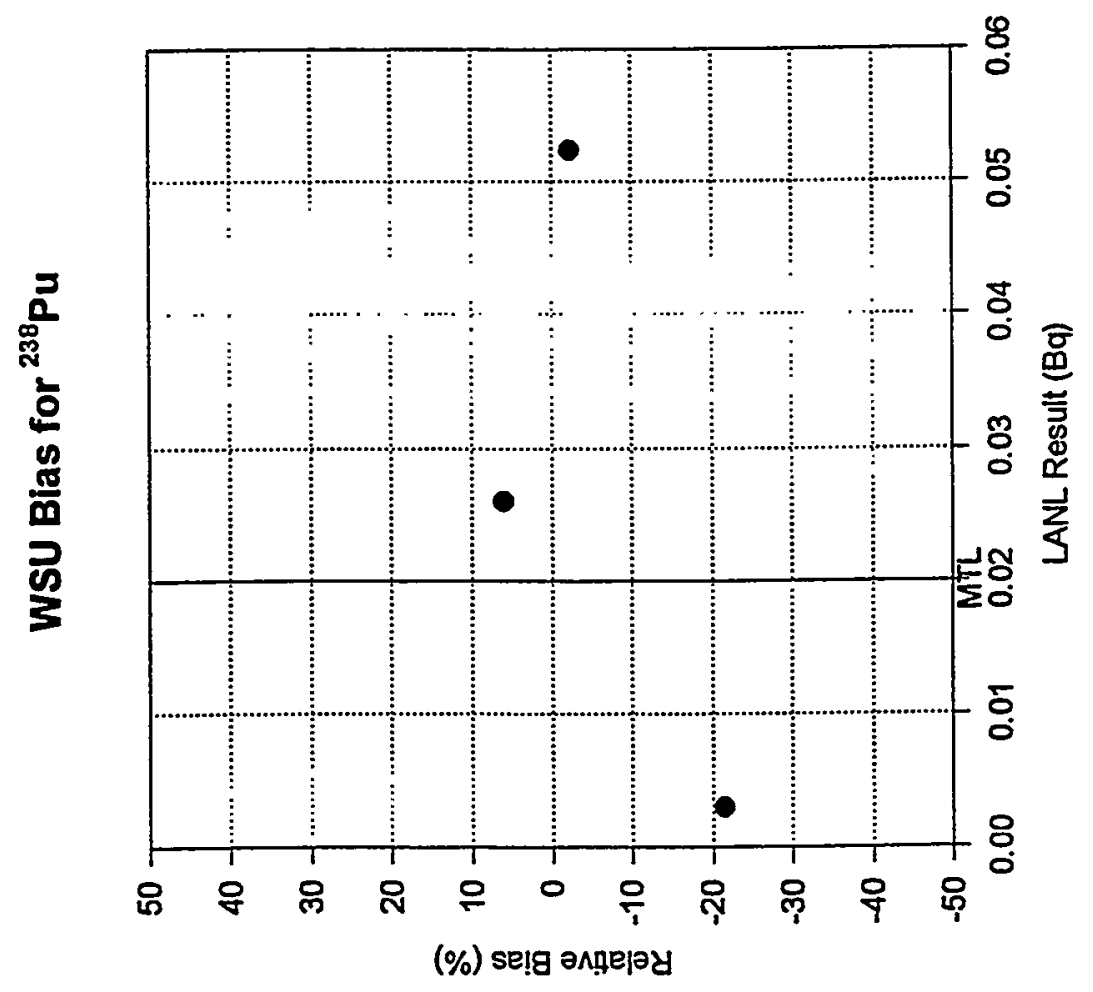




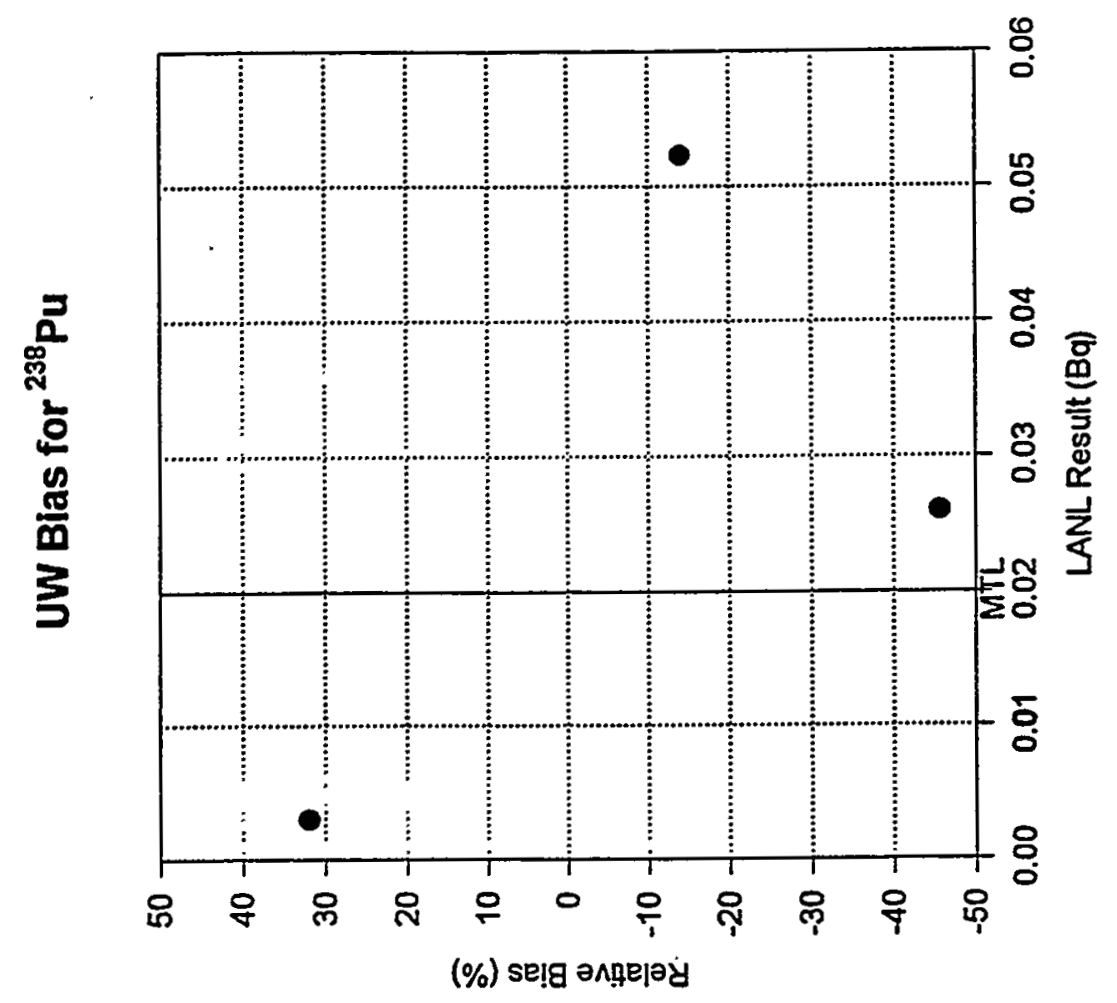


${ }^{239 / 240}$ Pu Results for Intercomparison 3

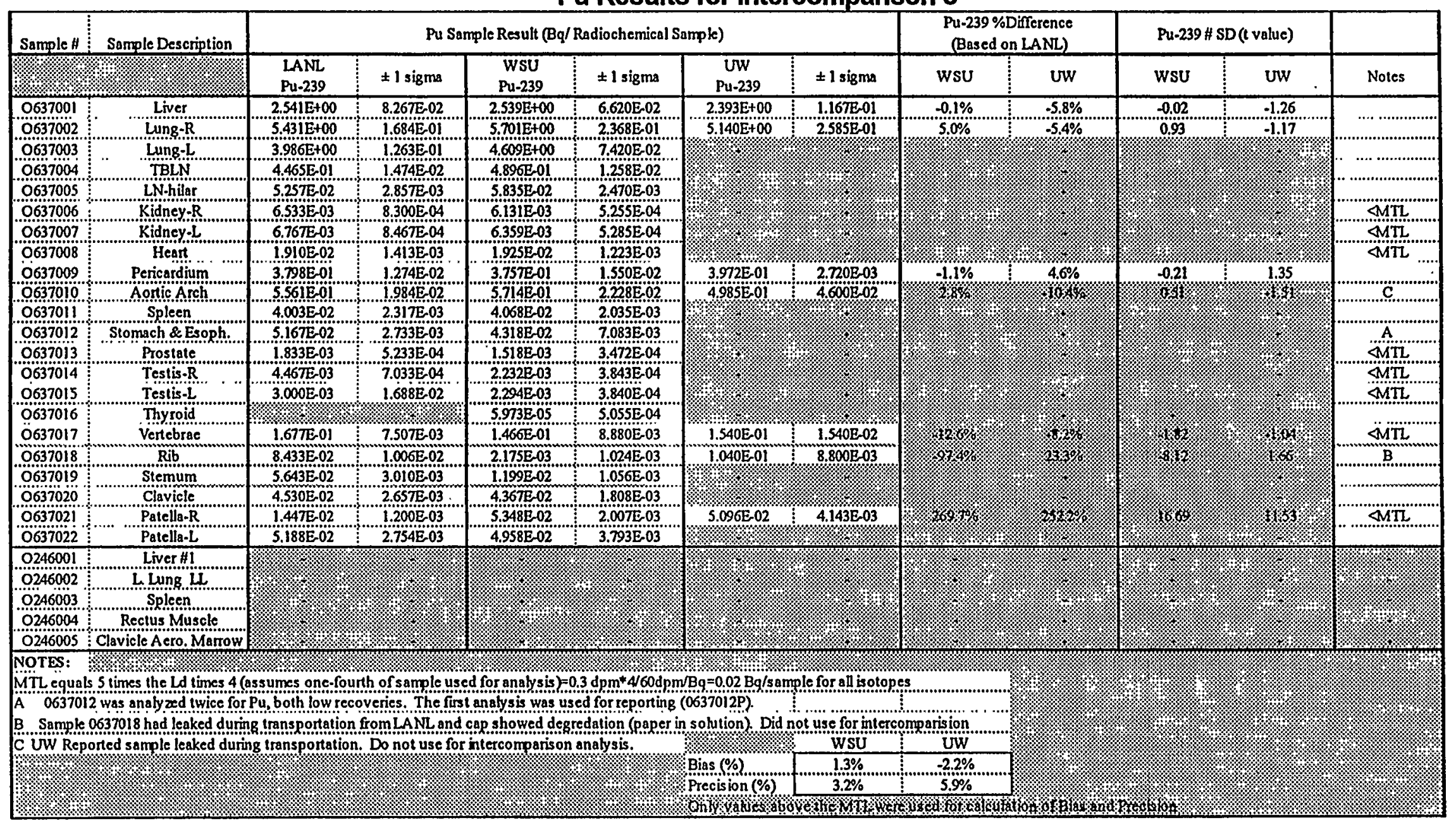




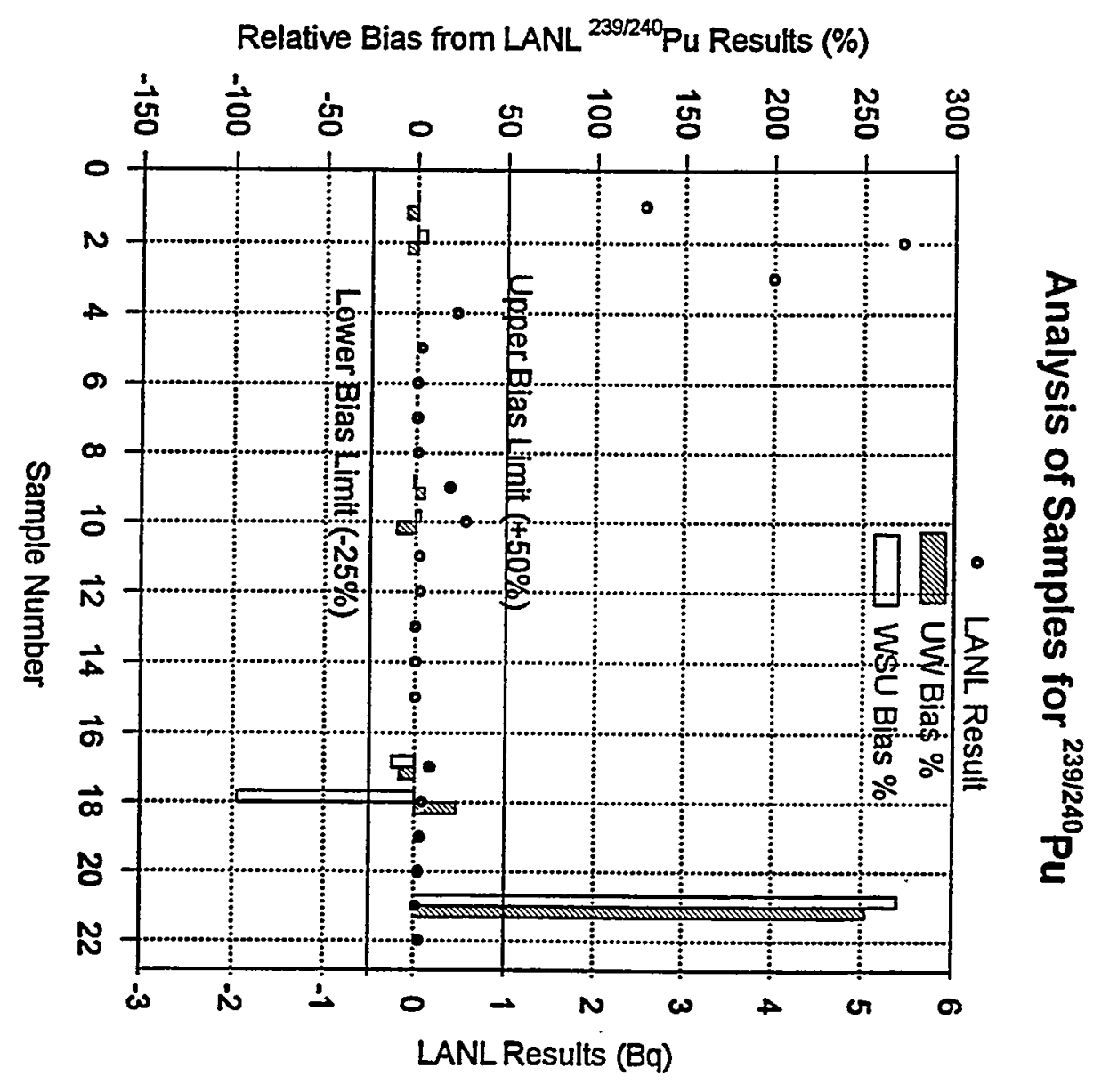




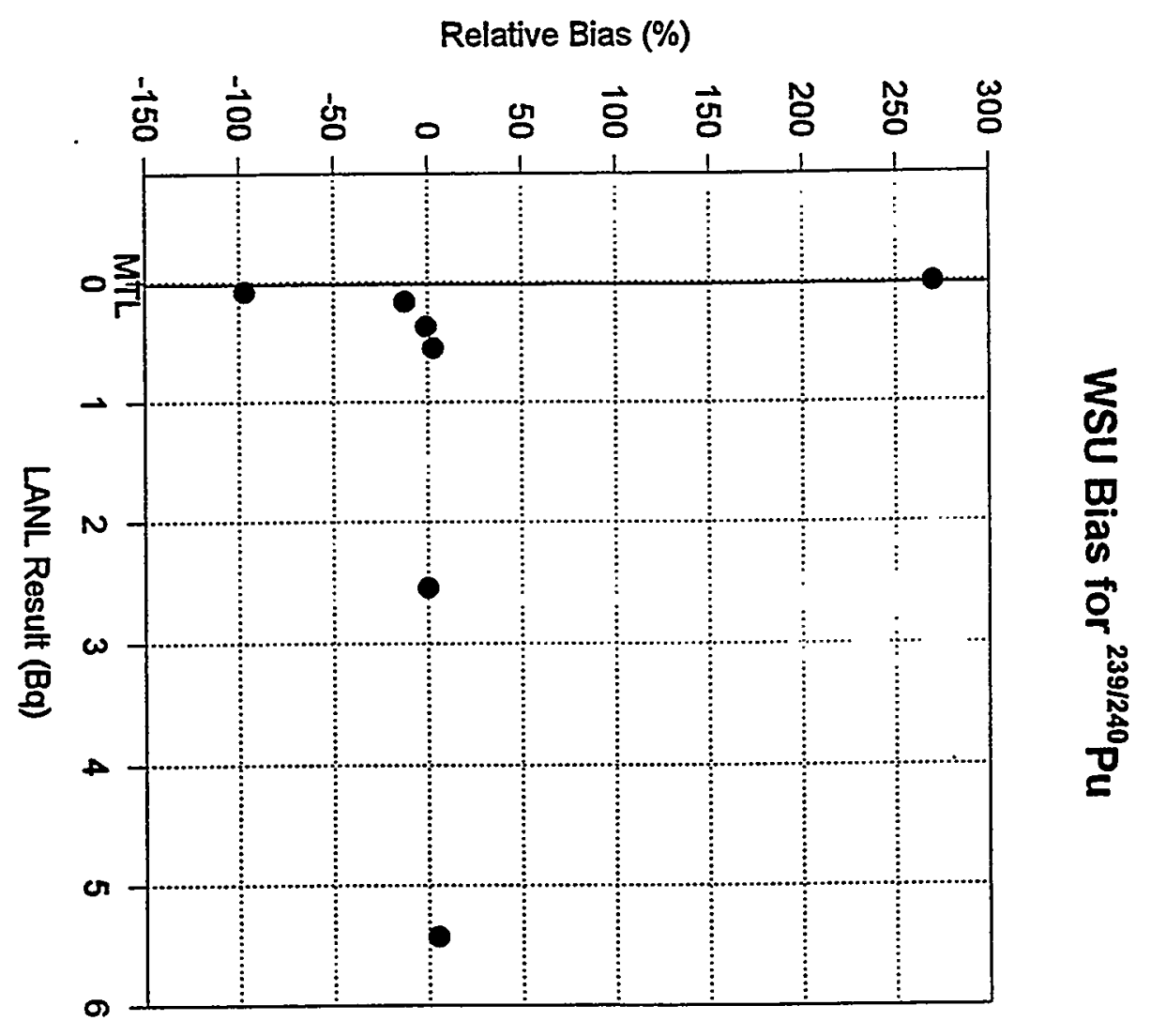




\section{UW Bias for ${ }^{239 / 240} \mathrm{Pu}$}

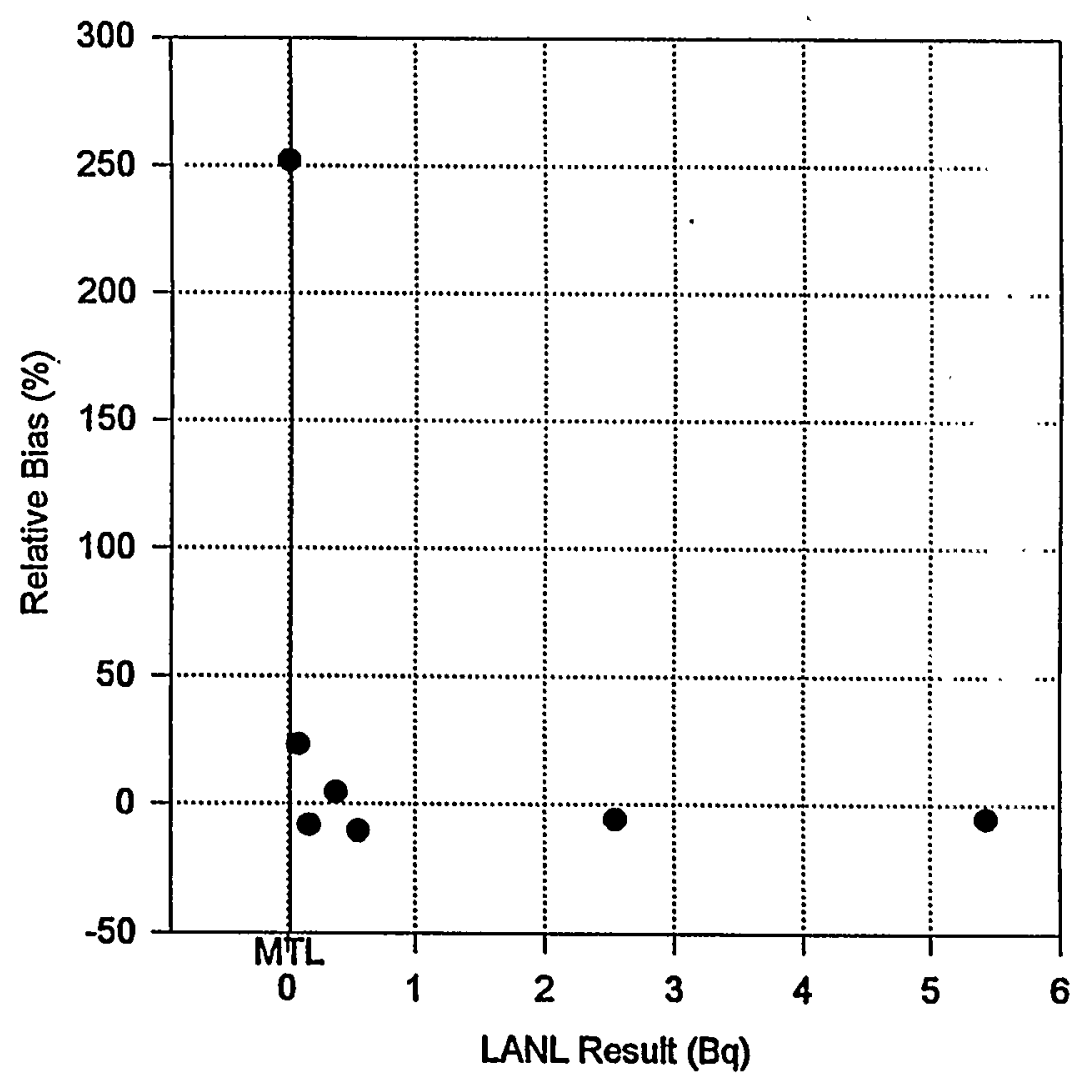


${ }^{241}$ Am Results for Intercomparison 3

\begin{tabular}{|c|c|c|c|c|c|c|c|c|c|c|c|}
\hline \multirow{2}{*}{ Sample \# } & \multirow{2}{*}{ Sample Description } & \multicolumn{5}{|c|}{ Am-241 Sample Result (Bq/Radiochemical Sample) } & \multicolumn{2}{|c|}{$\begin{array}{l}\text { Am-24l \%Difference } \\
\text { (Based on LANL) }\end{array}$} & \multicolumn{2}{|c|}{$A m-241$ \# SD (t test) } & \multirow[b]{2}{*}{ Notes } \\
\hline & & $\begin{array}{l}\text { LANL } \\
\text { Am-24l }\end{array}$ & \pm 1 sigma & $\begin{array}{c}\text { WSU } \\
\text { Am-24l }\end{array}$ & $\begin{array}{l}\text { UW } \\
\text { Am-241 }\end{array}$ & \pm 1 sigma & wsU & UW & WSU & ww & \\
\hline 0637001 & Liver.... & & & & & & & & & & \\
\hline 0637002 & Luns R & & & & & & & & & & \\
\hline .0637003. & Lung-L... & & & & & & & & & & \\
\hline 0637004 & TELN & & & & & & & & & & \\
\hline 0637005 & Nonghilar & & & & & & & & & & \\
\hline $\begin{array}{l}0637006 \\
0637007\end{array}$ & Kidney-R & & & & & & & & & & \\
\hline $\begin{array}{l}0637007 \\
0637008\end{array}$ & - lo & & & & & & & & 4 & & \\
\hline 0637009 & Pencardium & & & & & & & & & & \\
\hline 6637010 & Aortic Arch & & & & & & & & & & \\
\hline $06370 ! 1 !$ & ..................npleen & & & & & & & & & & \\
\hline 0637012 & Stomach \& Esoph. & & & & & & & & & & \\
\hline 0637013 & Prostate & & & & & & $\%$ & & & & \\
\hline 0637014 & $\begin{array}{l}\text { Testis-R } \\
\text { Testis-L }\end{array}$ & & & & & & & & & & \\
\hline 0637015 & $\begin{array}{l}\text { Testis-t } \\
\text { Thyroid }\end{array}$ & & & & & & & & & & \\
\hline 6637016 & $\begin{array}{l}\text { Thyroid } \\
\text { Vertebrae }\end{array}$ & & & & & & & & & & \\
\hline 0637017 & $\begin{array}{ll}\text { Vetebrae } \\
\text { Vent }\end{array}$ & & & & & & & & & & \\
\hline 0637018 & Stemum & & & & & & & & & & \\
\hline 6637019 & $\begin{array}{l}\text { Slemum } \\
\text { Clavicle }\end{array}$ & & & & & & & & & & \\
\hline 0637020 & $\begin{array}{l}\text { Clavicle } \\
\text { Patella-R }\end{array}$ & & & & & & & & & & \\
\hline 637021 & $\begin{array}{l}\text { Patella-R } \\
\text { Patella-L }\end{array}$ & & & & & & & & & -3.5 & \\
\hline 0637022 & $\frac{\text { Palella-L }}{\text { Liver } \# 1}$ & $2.971 E+03$ & - & $2.914 \mathrm{E}+03 \quad 6.786 \mathrm{E}+01$ & $2.398 \mathrm{E}+03$ & $2.294 \mathrm{E}+02$ & $-1.9 \%$ & - l-19.3\% & -0.8 & 06 & \\
\hline 0246001 & $\begin{array}{l}\text { Liver } \# 1 \\
\text { L. Lung Le. }\end{array}$ & $2.539 \mathrm{E}+02$ & $\therefore$ & $2.420 \mathrm{E}+02 \quad 6.367 \mathrm{k}+00$ & $2463 \mathrm{E}+02$ & $2.296 \mathrm{E}+01$ & $4.7 \%$ & $-3.0 \%$ & .1.1..... & -0.5 & \\
\hline 0246002 & 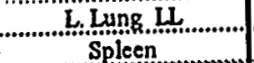 & $4.407 \mathrm{~F}+01$ & 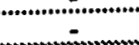 & $4.322 \mathrm{E}+01 \quad 9700 \mathrm{E} 01$ & $4.294 \mathrm{E}+01$ & $2.584 \mathrm{E}+00$ & $-1.9 \%$ & $-26 \%$ & -0.9 & . & \\
\hline 0246003 & Spleen & $1.810 \mathrm{E}+01$ & & $\begin{array}{ll}4.346 \mathrm{E} 01 \\
1.830 \mathrm{E}+01\end{array}$ & $1.832 \mathrm{E}+01$ & $1.908 E+00$ & $1.1 \%$ & $1.2 \%$ & 0.5 & 0.2 & .............. \\
\hline 0246004 & & & $2.630 \mathrm{E}-01$ & $\begin{array}{l}1.139 \mathrm{E}-01 \\
7.170 \mathrm{E}+00\end{array}$ & $\frac{1.751 \mathrm{E}+00}{6.7010}$ & 5.584E-01 & $8.6 \%$ & $1.5 \%$ & 1.4 & 0.2 & \\
\hline 0246005 & Mavicle Acro. Marrow & $6.600 \mathrm{E}+00$ & $2.630 \mathrm{E}-01$ & 1.10D+00 & O.NIEN & & & & & & \\
\hline NOTES: & $\begin{array}{l}\text { \% } \\
\text { s stimes the ta times } 44\end{array}$ & sumes onceff & of sample & or anatysis $=0.3 \mathrm{dpm} * 4600$ & $=0.02 \mathrm{~B}$ & & & & & & \\
\hline M 063701 & $\begin{array}{l}\text { Stimes the Ld times } 4 \text { (a } \\
\text { iwes analyzed twice for }\end{array}$ & $\begin{array}{l}\text { sumes one-f } \\
\text { uboth low }\end{array}$ & $\begin{array}{l}\text { ofsample } \\
\text { eries. The }\end{array}$ & nalys is was used for reportin & $0637012 P)$ & & & & & & \\
\hline A.......... & 2 was analyzed twice for & Gransportio & romLANL an & p showed degredation (paper & solution D Did & of use for inter & mparision & & & & \\
\hline B Sample & 0637018 had leaked durin & transpontatio & TomLANL an & p r & & wsu & uw & & & & \\
\hline & & & & & Bias (\%) & $0.2 \%$ & $-4.4 \%$ & & & & \\
\hline & 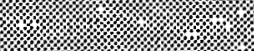 & & & "/\% & Precision (\%) & $5.1 \%$ & $8,6 \%$ & & & & \\
\hline
\end{tabular}




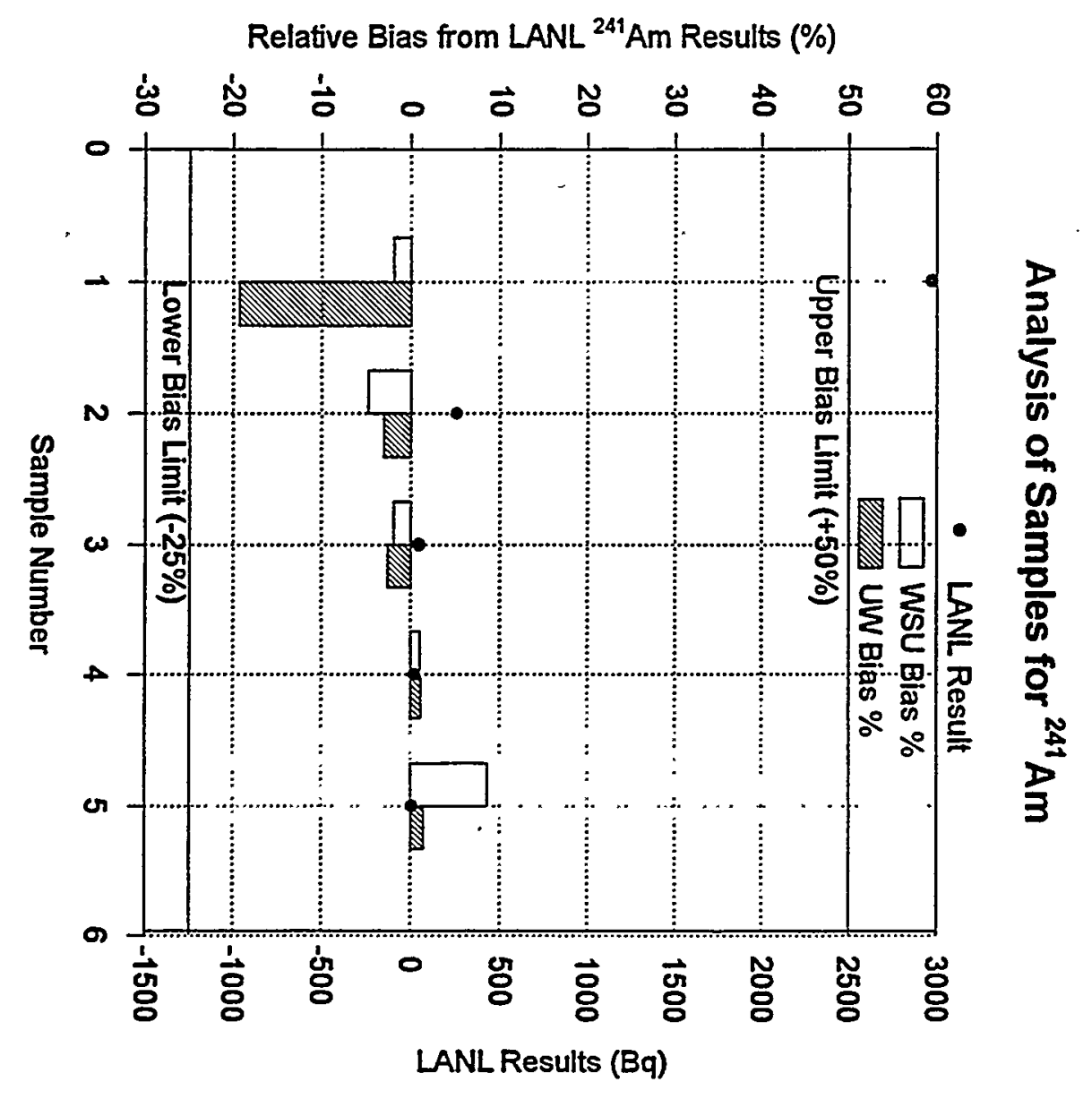




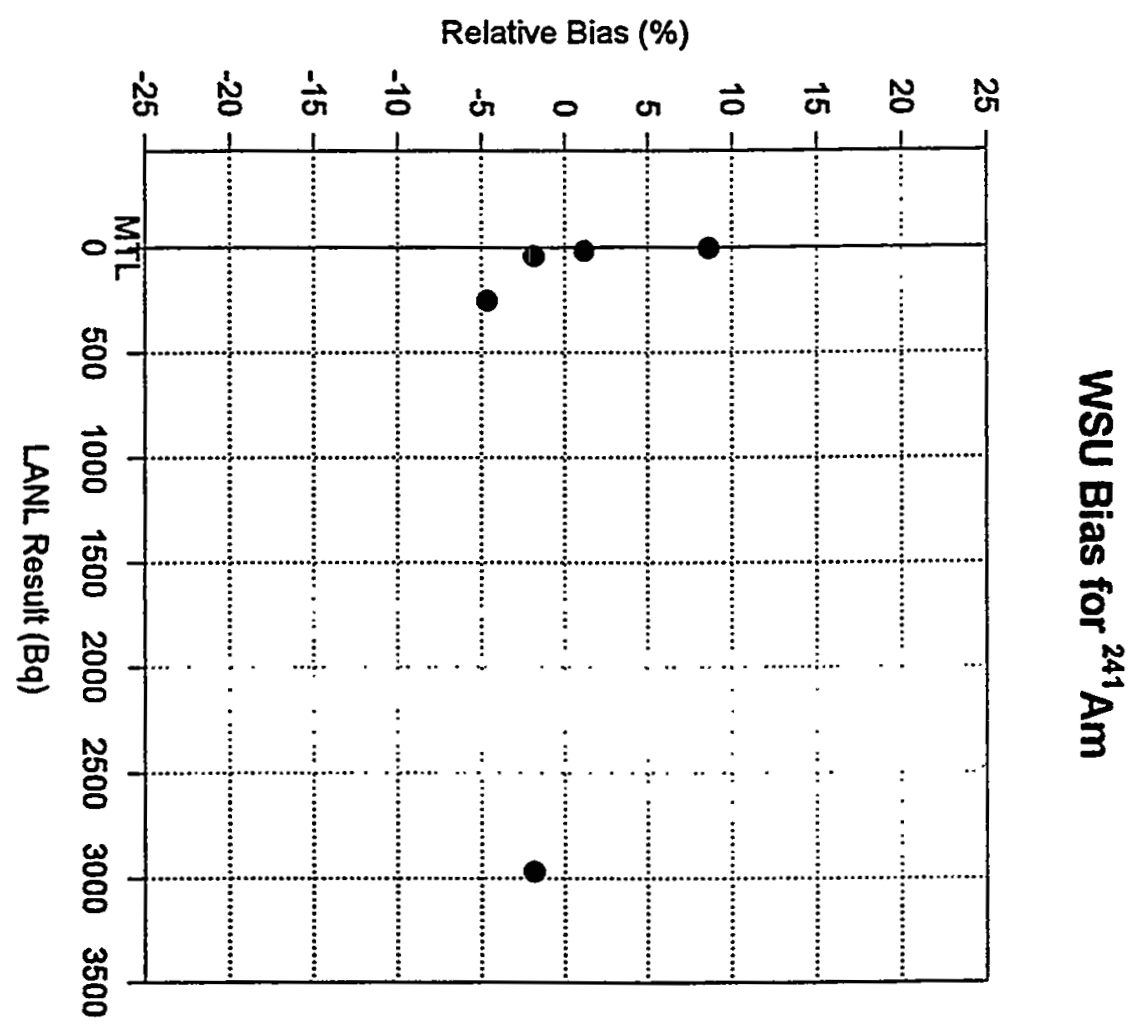




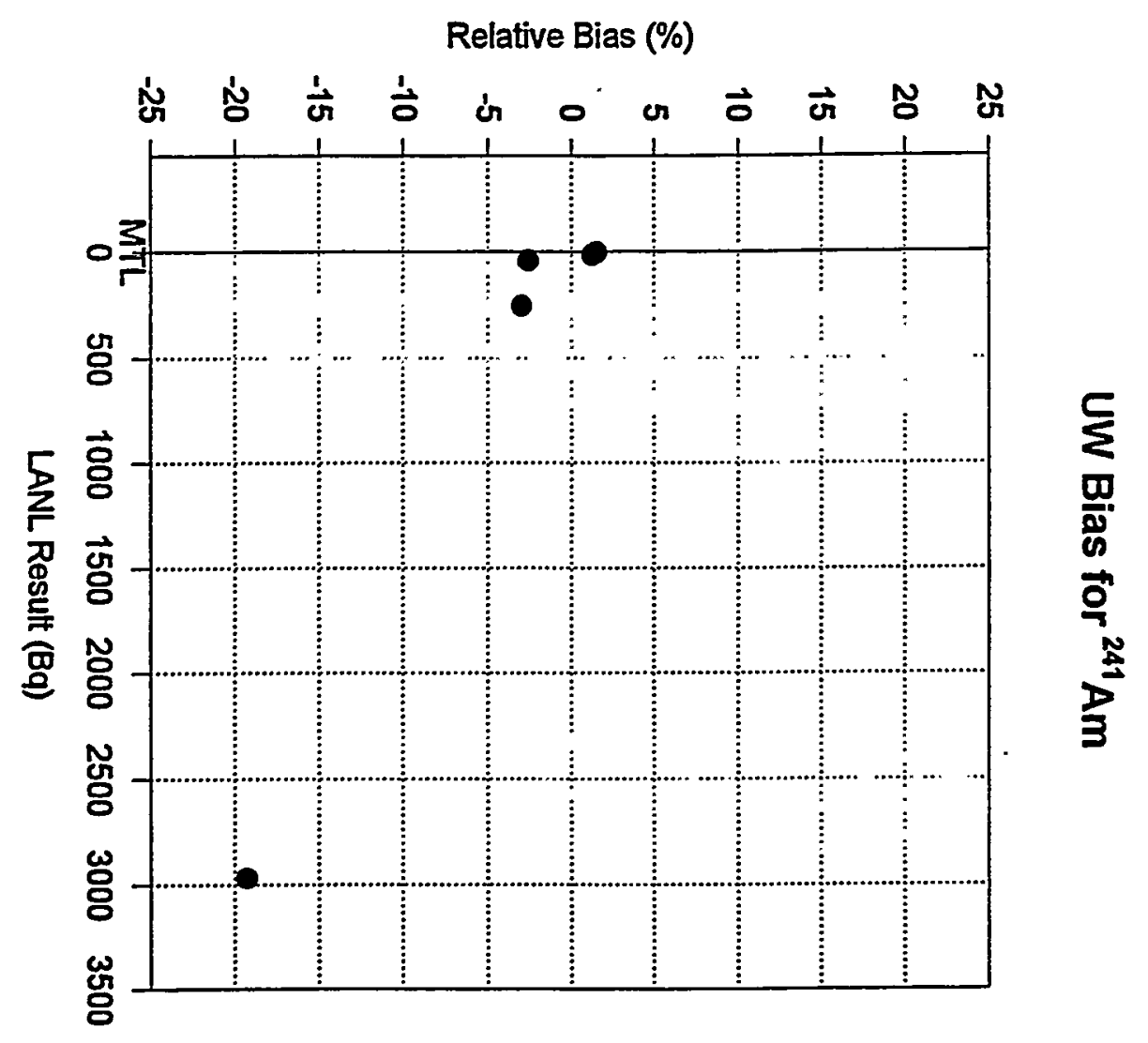




\section{Resuits for Intercompanison 4}

Intercomparison 4 assesses the complete radiochemical analysis method of samples by WSU. Two bottles of NIST SRM 4352, human liver, and two bottles of NIST SRM 4351, human lung, were prepared for analysis using the complete dissolution methods and radiochemical separation techniques as described in the USTUR Radiochemical Analysis Procedures Manual, (1 $1^{\text {st }}$ edition) for selected actinides. The entire content of each SRM bottle was used as a sample. Each SRM sample was then run in duplicate, using an aliquot of solution equal to one-half of the sample solution for each analysis. The average of the four values for each SRM were then compared against the NIST certified isotopic values based on the $95 \%$ confidence limits reported for the SRM and the $95 \%$ confidence limits of the WSU result.

The results of these analyses indicated no significant difference between the NIST SRM reported activity concentration and the WSU results at the $95 \%$ confidence level. 
Intercomparison 4 Results

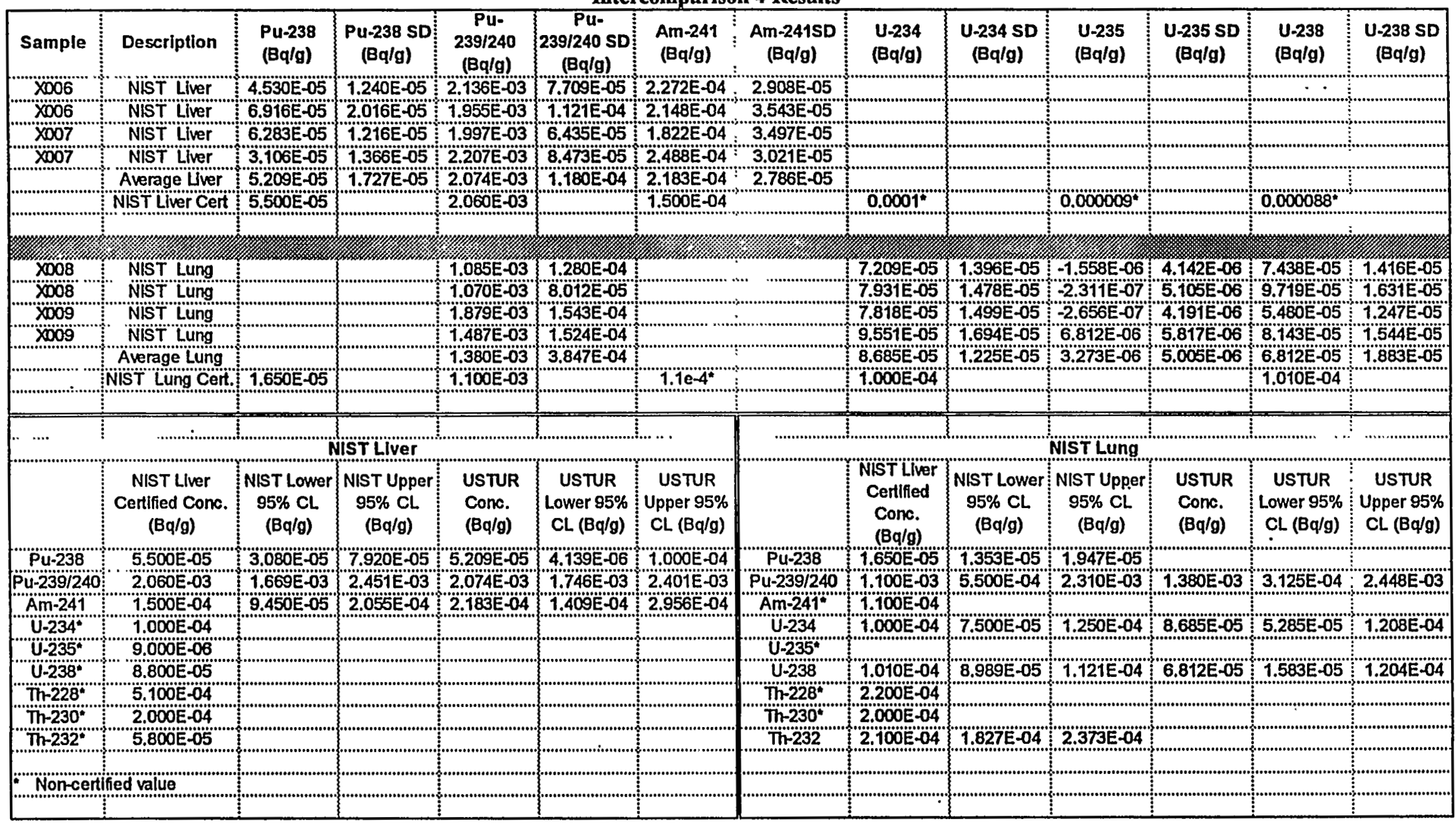




\subsection{Conclusions}

Based on the outcome of these first four intercomparisons, the radiochemical analysis of USTUR tissue samples has been successfully transferred from LANL to WSU-Pullman. WSU has successfully adopted LANL's radiochemical methods and put in place a radiochemistry analysis program to meet the analytical needs of the USTUR program. 


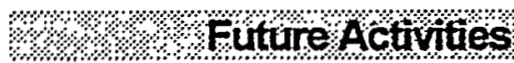

There are several additional studies which need to be performed over the next year. We are currently evaluating a procedure for the analysis of $\mathrm{Th}$ in human tissues which will be intercompared against the results for Case 1001 and NIST SRM's. The analysis of the SRM's will be repeated for plutonium, americium and uranium (where certified values exist) as part of the USTUR Radiochemistry Project routine QA program. The USTUR will also participate in the NIST bone ash intercomparison.

Additionally there will be continued evaluations of new procedures which are being developed for the analysis of actinides in tissues. 


\section{Appenax A}

\section{Radiochemical Methods for the University of Washington}

1. Weigh the bottle + sample. Pipette $5 \mathrm{ml}$ into a $200 \mathrm{ml}$ beaker. Re-weigh the bottle to obtain the weight of the sample.

2. Add to the beaker $10 \lambda$ Am-243 tracer, $10 \lambda$ Pu-242 tracer, and $300 \lambda=6 \mathrm{mg}$ Fe-carrier, and evaporate to dryness.

3. Add $15 \mathrm{ml} 8 \mathrm{M}$ HNO3 and few $\mathrm{mg} \mathrm{NaNO} 2$, boil the solution, cool, and pass through the Pu-column (AG 1-X8 100-200 mesh anion exchange resin prepared in $8 \mathrm{M} \mathrm{HNO}_{3}$ ).

4. Wash the column with $8 \mathrm{M}$ HNO3 until all the Fe is removed from the column. Evaporate the column effluents to dryness for Am measurements.

5. Elute the Pu with $40 \mathrm{ml} 0.4 \mathrm{M} \mathrm{HCl} / 0.01 \mathrm{M} \mathrm{HF}$ and evaporate the eluent to dryness.

6. Add 2-3 ml of $2 \mathrm{M} \mathrm{NH}_{4} \mathrm{SCN} / 0.1 \mathrm{M}$ formic acid to the americium fraction and allow to stand overnight to assure dissolution of the sample.

7. Prepare an EIChroM TEVA-Spec column by washing with $3 \mathrm{ml}$ water followed by $5 \mathrm{ml}$ of $2 \mathrm{M}$ NH4SCN/0.1 M formic acid.

8. Transfer the sample to the column and wash the beaker with four $0.5-1 \mathrm{ml}$ of thiocynate solution and add them to the column.

9. Wash the column with $1 \mathrm{M} \mathrm{NH}_{4} \mathrm{SCN} / 0.1 \mathrm{M}$ formic acid until all the iron is removed from the column.

10. Elute the Am with $20 \mathrm{ml} 2 \mathrm{M} \mathrm{HCl}$. Add $3 \mathrm{ml} \mathrm{Conc.} \mathrm{HNO}_{3}$ to the solution and evaporate to dryness.

\section{ELECTRODEPOSITION}

1. To the dry beakers containing $\mathrm{Pu}$ and Am fractions add 10 drops of $\mathrm{Conc} . \mathrm{H}_{2} \mathrm{SO}_{4}, 2 \mathrm{ml} \mathrm{H} 2 \mathrm{O} 2(30 \%)$ and $10 \mathrm{ml}$ water. Cover with a watch glass and evaporate to fumes of sulfuric acid.

2. Dilute with 10-15 ml water, boil for few minutes, cool, adjust the $\mathrm{pH}$ to 2.5-3.0 with Conc. $\mathrm{NH}_{4} \mathrm{OH}$, transfer to electroplating cells, and electroplate for 3 hours at $0.2 \mathrm{Amp}$.

3. Take the stainless steel disks out, rinse, flame, and alpha count. Counting time $\geq 23$ hours.

\section{EQUATIONS}

Equation for calculation of PU-239,240 activity and error:

$$
A_{\mathrm{Pu}-239} \pm a_{\mathrm{Pu}-239}=\frac{C_{\mathrm{Pu}-239} \pm \mathrm{c}_{\mathrm{Pu}-239}}{C_{\mathrm{Pu}-242} \pm \mathrm{C}_{\mathrm{Pu}-242}} \times A_{\mathrm{Pu}-242} \pm a_{\mathrm{Pu}-242}-(\text { Blank } \pm b)
$$


Where:

$A_{\text {pu-239 }} \pm a_{\text {pu-239 }}=$ Activity of Pu-239 and the associated error

$\left.\mathrm{C}_{\mathrm{pu-239}} \pm \mathrm{C}_{\mathrm{Pu}-239}=[\mathrm{Cg} \pm \mathrm{Cg})^{1 / 2}\right]-\left[\mathrm{C}_{\mathrm{b}} \pm\left(\mathrm{C}_{\mathrm{b}}\right)^{1 / 2}\right]$

$\mathrm{C}_{\mathrm{pu}-239}=$ Net counts under PU-239 peak

$c_{p u-239}=$ Error associated with Pu-239 net counts

$\mathrm{C}_{\mathrm{B}}=$ Gross counts under Pu-239 peak

$\left(C_{g}\right)^{1 / 2}=$ Error associated with gross counts under $\mathrm{Pu}=-239$ peak

$\mathrm{C}_{\mathrm{b}}=$ Background counts in Pu-239 channels (for the same counting time as sample)

$\left(C_{b}\right)^{1 / 2}=$ Error associated with background counts in Pu-239 channels

$\left.\mathrm{C}_{\mathrm{pu}-242} \pm \mathrm{C}_{\mathrm{Pu}-242}=[\mathrm{Cg} \pm \mathrm{Cg})^{1 / 2}\right]-\left[\mathrm{C}_{\mathrm{b}} \pm\left(\mathrm{C}_{\mathrm{b}}\right)^{1 / 2}\right]$

$\mathrm{C}_{\mathrm{pu}-242}=$ Net counts under $\mathrm{Pu}-242$ peak

$c_{\text {pu-242 }}=$ Error associated with Pu-242 net counts

$\mathrm{C}_{\mathrm{B}}=$ Gross counts under $\mathrm{Pu}-242$ peak

$\left(C_{g}\right)^{1 / 2}=$ Error associated with gross counts under Pu-242 peak

$\mathrm{C}_{\mathrm{b}}=$ Background counts in Pu-242 channels (for the same counting time as sample)

$\left(C_{b}\right)^{1 / 2}=$ Error associated with background counts in Pu-242 channels

$A_{\mathrm{pu}-242} \pm \mathrm{a}_{\mathrm{Pu}-242}=$ Activity of $\mathrm{Pu}-242$ tracer and the corresponding uncertainty

Blank $\pm b=$ Average blank value and the corresponding uncertainty. A similar equation is used for Am241 calculations.

\section{ERROR PROPAGATION}

Operation

$(A \pm a)+(B \pm b)$

$(A \pm a)-(B \pm b)$

$(A \pm a) \times(B \pm b)$

$(A \pm a) /(B \pm b)$
Answer

$A+B$

$A-B$

A.B

$\mathrm{A} / \mathrm{B}$
Uncertainty

$\left(a^{2}+b^{2}\right)^{1 / 2}$

$\left(a^{2}+b^{2}\right)^{1 / 2}$

A.B $\left.[\mathrm{a} / \mathrm{A})^{2}+(\mathrm{b} / \mathrm{B})^{2}\right]^{1 / 2}$

$\left.\mathrm{A} / \mathrm{B}[\mathrm{a} / \mathrm{A})^{2}+(\mathrm{b} / \mathrm{B})^{2}\right]^{1 / 2}$ 

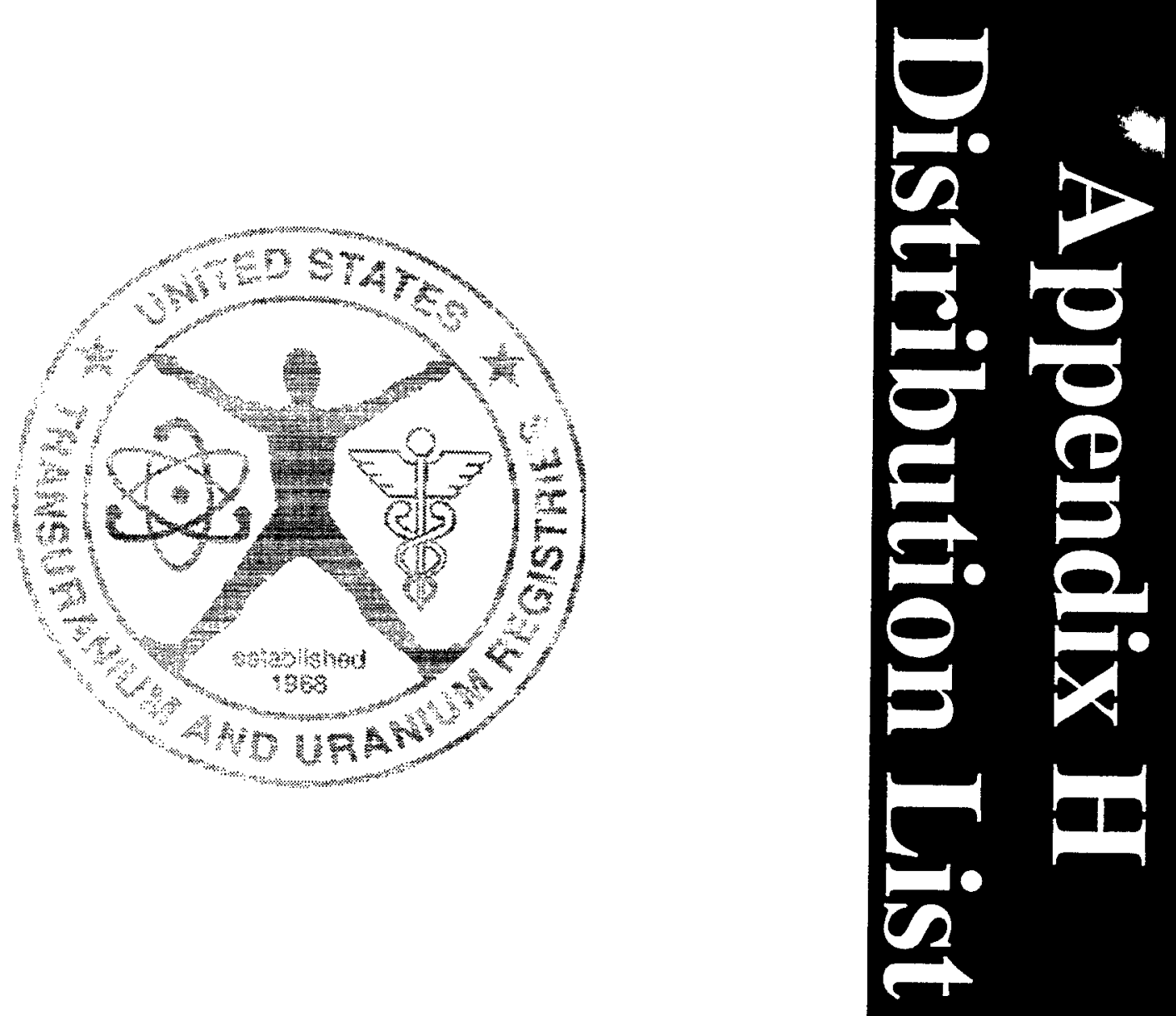


\section{Distribution List}

Dr. Mahmoud M. Abdel-Monem, Dean College of Pharmacy, Wegner 105E Washington State University Pullman, WA 99164-6510

Dr. S. Abrahamson 2012 Waunona Way Madison, WI 53713

Captain David Adams

A.F. Radiation Assessment Team USAF OEHL/RZA

Brooks AFB, TX 78235-5501

Mr. Steven Adams

IT Corporation 4330 S. Valley View, Suite 114

Las Vegas, NV 89103-4047

Mr. Andor Andrasi

KFKI Atomic Energy Research Institute H-1525 Budapest P.O. Box 49 HUNGARY

Director

Argonne National Laboratory 9700 South Cass Avenue Argonne, IL 60439

Atomic Energy of Canada Limited Scientific Doc. Dist. Office Sta. 14, Chalk River Nuclear Labs Chalk River, KOJ 1JO Ontario, CANADA

Director

Agency for Toxic Subtances

and Disease Registry

1600 Clifton Rd. MS E-56

Atlanta, GA 30333

Dr. Irina A. Avonova

Department of Radiology

RSFSR Ministry of Public Health

8, Mira, St.

197101, St. Petersburg

RUSSIA
Dr. P. Bannasch

Department of Cell Pathology

German Caner Research Center

Im Neuenheimer Feld 280

62120 Heildelburg,

GERMANY

Mr. Don C. Barg

Radiological Engineer

P.O. Box 1625

Idaho Falls, ID 83415

Mr. Mark C. Becker

Public Affairs Manager

EG\&G Mound Applied Technologies

P.O. Box 3000

Miamisburg, OH 45343-3000

Dr. Luiz Bertelli

Rua Geminiano Gois

170 BL-I Apt. 202

Rio De Janeiro - RJ

22743-670

BRAZIL

Dr. R. W. Bistline

DOE/RFFO, HP Group

P.O. Box 928

Golden, CO 80402-3408

Dr. B.B. Boecker

Inhalation Toxicology Research Institute

P.O. Box 5890

Albuquerque, NM 87185

Dr. John Boice

REB/NCI EPN 408

Bethesda, MD 20892

Dr. Thomas Borak

Dept. of Radiation Health Science

Colorado State University

Ft. Collins, CO 80523

Dr. B.D. Breitenstein, Ir.

Brookhaven National Lab, BLDG. 490

P.O. Box 83

Upton, NY 11973 
Dr. Allen Brodsky

Allen B. Consultants

2765 Ocean Pines

Berlin, MD 21811-9127

Director, Brookhaven National Laboratory

Associated Universities, Inc.

Building 490

Upton, NY 11973

Dr. Antone L. Brooks

Battelle, Pacific Northwest National Lab

P.O. Box 999, K8-07

Richland, WA 99352

Dr. Barbara Brooks

U.S. Dept. of Energy

Office of Health, EH-42, GTN

Washington, DC 20585

Dr. A. R. Britcher

British Nuclear Fuels, Hinton House

Risley, Warrington WA3 6AS

UNITED KINGDOM

Dr. L.A Buldakov

Deputy Director

Institute of Biophysics

Zhivopisnaya 4 Moscow,

RUSSIA

Dr. William Burr

Oak Ridge Associated Universities

P.O. Box 117

Oak Ridge, TN 37830

Director

Pacific Northwest National Laboratory

P.O. Box 999

Richland, WA 99352

Dr. E.H. Carbaugh

Battelle, PNNL

P.O. Box 999

Richland, WA 99352

Dr. Paul Charp

Agency for Toxic Subtances

and Disease Registry

1600 Clifton Rd., MS:E-56

Atlanta, GA 30333

Dr. Larry P. Clevenger

Sandia Laboratories - 3300

P.O. Box 5800

Albuquerque, NM 87123
Prof. Norman Cohen

60 Still Road

Monroe, NY 10950

Ms. Gail Cole

EG\&G Mound Applied Technologies

P.O. Box 3000

Miamisburg, $\mathrm{OH} 45343$

Dr. Daniel E. Conrad

Martin Marietta Energy Systems, Inc.

P.O. Box 2009

Oak Ridge, TN 37831

Mr. J.P. Corley

2213 Torbett Street

Richland, WA 99352

Dr. David Coulston

BNFL

1002607 England Regd. Office

Risley Warrington

Cheshire WA3/6AS

ENGLAND

Dr. W. W. Crosbie

Authority Chief Medical Officer

Building 147, Harwell Lab

Oxfordshire, OX11 ORA

ENGLAND

Mr. Jean Pierre Culot

Boeretang 200

B-2400 MOL

BELGIUM

Dr. Robert T. Cutting

Medical Dept.

Savannah River Site

Aiken, SC 29808

Dr. Marina O. Degteva

Ural Research Center

Medgorodok Chelyabinsk

454076

RUSSIA

Ms. Martha DeMarre

REECO

P.O. Box 98521

Las Vegas, NV 89193-8521 
Dr. Gordon DePuey

St. Lukes Hospital

Amersterdam Ave. at 114th St.

New York, NY 100258521

Dr. Marc F. Desrosiers

U.S. Department of Commerce, NIST

Building 245, Room C229

Gaithersburg, MD 20899

Mr. Bruce B. Dicey

U.S. Environmental Protection Agency

Environmental Monitoring Systems Lab

Radiation Sciences Division

P.O. Box 93478

Las Vegas, NV 89193-2929

Dr. Hans Doerfel

HS/D

Kerforschumgszentrum Karlsruhe

Postfach 3640, D-76021 Karlsruhe 1

GERMANY

Dr. Mildred A. Donlon

Armed Forces Radiobiology Research Institute

Bethesda, MA 20814-5145

Dr. Patricia W. Durbin

1150-70A Lawrence Berkeley Laboratory

1 Cyclotron Road

Berkeley, CA 94720

Dr. Keith Eckermann

Medical Sciences Division

Oak Ridge Institue of Science and Ed.

P.O. Box 117

Oak Ridge, TN 37831-0117

Dr. Merrill Eisenbud

340 Carolina Meadows Villa

Chapel Hill, NC 27514

Ms. Jill Fitch, Director

Radiation Protection Branch

61 Hindmarsh Square

P.O. Box 6, Rundle Mall 5000

Adelaide, South Australia

AUSTRALIA

Dr. John R. Frazier

Auxier and Associates

412 Executive Tower Dr., Suite 402

Knoxville, TN 37923

Dr. Marvin Fraser

US Department of Energy

OHER, GTN

Washington, DC 20585
Dr. Thomas Fritz

Argonne National Laboratory

9700 S. Cass Ave.

Argonne, IL 60439

Miss F. A. Fry

Secretary, NRPB

Chilton Didcot

OXON OXO11 QRQ

ENGLAND

Dr. Shirley Fry

ORISE

P.O. Box 117

Oak Ridge, TN 37831

Dr. F. J. Furman, Director

Medical Department, Bldg. 122

Rocky Flats Plant

P.O. Box 464

Golden, CO 80402

Ms. Marcie Gallagher

Agency for Toxic Substances

and Disease Registry

1600 Clifton Rd. MS E-56

Atlanta, GA 30333

Dr. A. Seaton Garrett

Oak Ridge National Laboratory

P.O. Box X

Oak Ridge, TN 37831

Dr. J.A. B. Gibson

Wayside, Wellshead

Harwell, Didcot

OXON OXO11 HD

UNTTED KINGDOM

Dr. Ethel Gilbert

Pacific Northwest National Laboratory

Box 999 MS P7-82

Richland, WA 99352

Professor Marvin Goldman

Department of Radiological Sciences

University of California Davis

Davis, CA 95616-8742

Dr. Robert Goldsmith

902 Beacon Square Port \#405

Gaithersburg, MD 20878 
Dr. Abel J. Gonzales, Deputy Director

Division of Nuclear Safety, IAEA

Wagramerstrasse 5, P.O. Box 100

A 1400 Vienna

AUSTRIA

Dr. W. Gossner

Institute for Strahlenbiologie

GSF-Forschungszentrum

D-85764 Oberschileimbheim

GERMANY

Max E. Benitz Library

Washington State University

100 Sprout Road

Richland, WA 99352

Mr. Richard Griffith

IAEA

Wagramerstrasse 5, P.O. Box 100

A-1400 Vienna

AUSTRIA

Dr. W.C. Griffith

Inhalation Toxicology Research Institute

P.O. Box 5890

Albuquerque, NM 87185

Dr. David H. Groth

Robert A. Taft Laboratories

4676 Columbia Parkway

Cincinnati, OH 45226

Mr. Arnaldo Guerrero

145 Jewell Street Apt. 3

San Rafael, CA 94901

Dr. R.A. Guilmette

Inhalation Toxicology Research Inst.

P.O. Box 5890

Albuquerque, NM 87185

Dr. Borje K. Gustafsson, Dean

College of Veterinary Medicine

Bustad 110

Washington State University

Pullman, WA 99164-7010

Mr. G. J. Ham

Radiological Protectional Board

Chilton, Didcot

Oxfordshire OX 11 ORA

ENGLAND

Hanford Health Information Network

P.O. Box $\mathrm{H}-76$

Richland, WA 99352
Mr. Fred Harrison

128 Russel Dr.

Selma, AL 36701

Mr. Frank Hawkins

Office of International Health

EH-44 GTN

US Department of Energy

Washington, DC 20585

Dr. Thomas W. Henn

Benton-Franklin District Health Dept.

506 McKenzie st.

Richland,m WA 99352

Dr. J.O. Hightower

Westinghouse Savannah River Co.

Bldg. 719-A

Aiken, SC 29808

Dr. Leo J. Hoge

P.O. Box 563

Saratoga Springs, NY 12866

Holland Library

Washington State University

Holland 1st. Fl

Pullman, WA 99164-5610

Mr. Mark D. Hoover

Inhalation Toxicology Research Institute

P.O. Box 5890

Albuquerque, NM 87185

Dr. E. Huberman

Argonne National Laboratory

9700 South Cass Ave.

Argonne, IL 60439

Mr. J. Humphreys

Biomedical Research Dept., AEAEE

Harwell Lab, B-551

OXON OX11 ORA

ENGLAND

Mr. Jerry B. Hunt

P.O. Box 2008, ORNL

Bldg. 4500-5, MS-6099

Oak Ridge, TN 37831-6099

Dr. J. Inaba

National Inst. of Radiological Science

Anagawa,4-9-1, Chib-shi, 263

JAPAN 
Dr. Kenneth G.W. Inn

Center for Radiation Research

U.S. Dept. of Commerce, NIST.

Bldg. 245, Rm C-229

Gaithersburg, MD 20899

Dr. Yuichi Ishikawa

Dept. Pathol. Cancer Inst.

1-37-1 Kami-ikebukuro

Toshima-ku, Tokyo 170

JAPAN

Dr. Seymour Jablon

6813 Persimmon Tree Rd.

Bethesda, MD 20817

Dr. O.W. Jones

Martin Marietta Energy Systems, Inc.

P.O. Box 2009, MS 8103

Oak Ridge, TN 37831-8103

Mr. Stan Jones

Martin Marietta Energy Systems

P.O. Box 628, MS 5020

Piketon, $\mathrm{OH} 45661$

Ms. Amy E. Johnson

Rocky Flats Workers Studies

4300 Cherry Creek Dr. S.

Denver, CO 80222-1530

Lt. Col. J. Christopher Johnson

HQAMC; AMCSG-R

5001 Eisenhower Ave.

Alexandria, VA 22333-0001

Dr. John R. Johnson

Battelle

Box 999, MS K3-57

Richland, WA 99352

Dr. A. Karaoglou

Comm. of the European Communities

DG XII.F.6

200, rue de la Loi

B-1049 Brussels

BELGIUM

Professor Alexander Kaul

Bundesamt fur Strahlenschutz

Albert-Schweitzer-Str. 18

D-3320 Salzgitter 1

GERMANY
Mr. Hisao Kawamura

Division of Radioecology

Natl. Institute of Rad. Sciences

3609 Isazaki, Hitachinaka,

Ibaraki 311-12

JAPAN

Dr. Charles Kelsey

11513 Kimbark Ct.

N. Potomac, MD 20878

Mr. Robert W. Keys

Los Alamos National Laboratory

P.O. Box 1663

MS M888

Los Alamos, NM 87545

Ms. Esther Kim

456 Crossroads Dr.

N. Augusta, SC 29841

Dr. Valentin F. Khokhryakov

Branch Biophysics Institute

Public Health Ministry of Russia

454065 Chelyabinsk-65

RUSSIA

Dr. Nina A. Koshumikova

Branch Biophysics Institute

Public Health Ministry of Russia

454065 Chelyabinsk-65

RUSSIA

Dr. Arnold Kramish

2065 Weathersfield Court

Reston, VA 22901

Mr. P.W. Kruger

U.S. Department of Energy

P.O. Box 550-A5-90

Richland, WA 99352

Mr. Ramney Kou

Public Health

P.O. Box 637

Dover, DE 19803

Dr. Emelie S. Lamothe

AECL Research

Chalk River Laboratories

Chalk River, Ontario KOJ 1JO

CANADA 
Director

Lawrence Berkeley Laboratory

1 Cyclotron Road

Berkeley, CA 94720

Director

Lawrence Livermore National Laboratory

P.O. Box 808

Livermore, CA 94550

Dr. Adam Lawson

British Nuclear Fuels Ltd.

2 Sellafield Cumbria CA20 1 PG

ENGLAND

Mr. Bruce Lawson

135 Westwood Lane

Oliver Springs, TN 37840

Dr. Dorothy Legarretta

National Association of Rad. Survivors

78 El Camino Real

Berkeley, CA 94705

Dr. Joyce Lipsztein

Rua Itajuru 132

Rio De Janeiro - RJ

22641-190

BRAZIL

Dr. Ray D. Lloyd

Radiobiology Laboratory, Bldg. 586

University of Utah

Salt Lake City, UT 84112

Mr. Robert Loesch

U.S. Dept. of Energy

EH-52, GTN, 270CC

19901 Germantown Rd.

Washington, DC 20874-1290

Director

Los Alamos National Laboratory

P.O. Box 1663

Los Alamos, NM 87545

Mr. Tim Lynch

Pacific Northwest Laboratory

P.O. Box 999 MS B1-60

Richland, WA 99352

Dr. David Marsden

St. Lukeís-Roosevelt Hospital

428 W. 59th. Street, NW

New York, NY 10019
Jerome B. Martin, CHP

20254 Watersrow Terrace

Germantown, MD 20874

Dr. Osamu Matsuoka

Abiko Laboratory, Central Research

Institute of Electric, Power Industry

Abiko 1646, Abiko-city,

Chiba 270-11

JAPAN

Dr. William R. McArthur

US Dept.. of Energy, GTN

Ofc. of Worker Protection Programs \& Hazards

Management, MS5097/2700CC

Germantown, MD 20874

Dr. J.F. McInroy

580 E. Lake Drive

Rio Rancho, NM 87124

Dr. Roger O. McClellan

President, CIIT

P.O. Box 12137

Research Triangle Park, NC 27709

Prof. Charles B. Meinhold, President

National Council on Radiation

Protection and Measurements

7910 Woodmont Ave, Suite 800

Bethesda, MD 20814

Mr. Richard A. Meserve

P.O. Box 7566

Washington, D.C. 20044

Mr. Sheldon Meyers

USEPA

3506 Dundee Dr.

Chevy Chase, MD 20815

Dr. William Mills

Program Committee

Risk Assessment, AD HOC

2915 Ascott Lane

Olney, MD 20832

Ms. Hollie Mooers

Richland Field Office

US DOE, MS A5-55

P.O. Box 550

Richland, WA 99352 
Mr. David S. Meyers

Lawrence Livermore Laboratory

Hazards Control Deparment, L-383

P.O. Box 5508

Livermore, CA 94550

Mr. Sheldon Meyers

3506 Dundee Drive

Chevy Chase, MD 20815

Mr. Mark Miller

NRL Code 1244

4555 Overlook Avenue SW

Washington, D.C. 20375-5320

Dr. Scott Miller

Division of Radiobiology, Bldg. 588

University of Utah

Salt Lake City, UT 84112

National Inst. of Radiation Science

Division of Rad. Hazards

9-1, 4-Chrome Anagawa, Chiba

JAPAN

Dr. Neal S. Nelson

U.S. Environmental Protection Agency (6602J)

Washington, D.C. 20460

Dr. Ruth Neta

US Department of Energy, EH-63, 270CC

19901 Germantown Road

Germantown, MD 20585-1290

Dr. Lee S. Newman

Pulmonary Division

National Jewish Center for Immunology and Respiratory Medicine

1400 Jackson St., D-104

Denver, CO 80206

Dr. W.R. Ney

National Council on Radiation Protection \& Measurement

7910 Woodmont Ave \#800

Washington, DC 20014

Director

Oak Ridge National Laboratory

P.O. Box 2008

Oak Ridge, TN 37831

Occupational Health Researcher Public Citizen Health Research Group 2000 P Street N.W.

Washington, DC 20036
Office of Scientific and Technical Info.

Oak Ridge Operations Office

P.O. Box 62

Oak Ridge, TN 37831

Mr. Peter Olsen

5201 Blue Jay Lane

W. Richland, WA 99352

Dr. Norris J. Parks

Civil Engineering Department

University of Texas

El Paso, TX 79969

Dr. John Peeters, Deputy Director

US Department of Energy, GTN

Occupational Medicine Programs Div., EH-43

Washington, DC 20585

Dr. Gerald R. Peterson

U.S. Dept. of Energy

Office of Health, EH-42, GTN

Washington, DC 20585

Dr. Harry Pettingill, Director

U.S. Department of Energy

19901 Germantown Road

Germantown, MD 20874

Dr. J.E. Phillips

Martin Marietta Energy Systems, Inc.

Paducha Gaseous Diffusion Plant

P.O. Box 1410

Paducah, KY 42001

S. Wynne Porter, CHP

Porter Consultants

125 Argyle Road

Ardmore, PA 19003

Dr. John Poston, Sr.

Department of Nuclear Engineering

Texas A\&M University

College Station, TX 77843

Mr. Howard M. Prichard

Auxier\& Associates, Inc.

412 Executive Tower Dr., Suite 402

Knoxville, TN 37923

Dr. Nicholas D. Priest

Biomedical Research Department, AEAEE

Harwell Laboratory, B-551

OXON OX11 ORA

ENGLAND 
Dr. Jerry Puskin

USEPA

11103 Old Coach Rd.

Potomac, MD 20854

Dr. Michael R. Quastel

Institue of Nuclear Medicine

Ben-Gurion University of the Negev

Soroka Medical Center

P.O. Box 151

Beer-Sheva, ISRAEL 84101

Mr. Robert M. Quillin

Radiation Control Division

Colorado Dept. of Health

4300 Cherry Creek Drive South

Denver, CO 80222-1530

Dr. Otto G. Raabe

Lab for Energy-Related Health Research

University of California

Davis, CA 95616

Dr. Rafailovich E. Lybchansky

State Scientific Centre - Biophysics Institute

456780 Chelyabinsk Region, Ozersk

RUSSIA

Dr. I. Riaboukhine

Radiation Scientist

World Health Organization

Geneva 2F

SWITZERLAND

Dr. Chester R. Richmond

Oak Ridge National Laboratory

Science Education Programs \& Ext. Relations

P.O. Box 2008-MS 6250

Oak Ridge, TN 37831-6250

Dr. S.A. Roberts

Martin Marietta Energy Systems, Inc.

P.O. Box 2003

Oak Ridge, TN 37831-7422

Dr. G.R. Roessler

Health Physics Newsletter

Rt. 1, Box $139 \mathrm{H}$

Elysian, MN 56028

Mr. Harold Rogers

860 Folsom Court

Carson City, NV 89705
Dr. R.E. Rowland

700 W. Fabyan Pkwy, Apt. 8C

Batavia, IL 60510

Mr. Sheldon Samuels, Director

Health, Safety and Environment

AFL-C10

815 16th. Street NW

Washington, DC 20006

Mr. D. Michael Schaeffer

Defense Nuclear Agency

Radiation Policy Division

6801 Telegraph Rd.

Alexandria, VA 22310-3398

Dr. Keith J. Schiager

690 E. 4149 South

Salt Lake City, UT 84107-2934

Dr. Robert Schlenker

Argonne National Laboratory

9700 South Cass Ave.

Argonne, IL 60439

Mr. M.C. Schumacher

25 W. 201 Highview Drive

Naperville, IL 60563

Dr. Bobby Scott

Inhalation Toxicology Research Institute P.O. Box 5890

Albuquerque, NM 87185

Dr. Glenn T. Seaborg

Lawrence Berkeley laboratory

1 Cyclotron Road, Bldg. 70A Room 3307

Berkeley, CA 94720

Dr. Fritz A. Seiler

4101 Lara Drive N.E.

Albuquerque, NM 87111

Dr. Paul Seligman

EH-142, GTN

US Department of Energy

Washington, DC 20885

Mr. Hugo Simenson

Sunhedsstryrelsen

Statens Institut for Stralehygiene

Frederikssundsvej 378

2700 Bronshoj

DENMARK 
Dr. N.P. Singh

University of Utah 4412 Fortuna Way

Salt Lake City, UT 85117

Dr. Kenneth W. Skrable

Department of Physics

University of Lowell

Lowell, MA 01854

Dr. A.J.M. Slovak

Brittish Nuclear Fuels Ltd.

2 Sellafield Cumbria

CA20 1 PG

ENGLAND

Dr. James M. Smith

Centers For Disease Control

MS F-35

4770 Buford Hwy N.E.

Atlanta, GA 30341-3724

Mr. Grover Smithwick

Oak Ridge Operations

DOE Federal Building

Oak Ridge, TN 37830

Mr. Michael Soldano

FERMCO

P.O. Box 538704, MS-31

Cincinnati, $\mathrm{OH}$ 45253-8704

Dr. A. Spiethoff

Department of Cell Pathology

German Cancer Research Center

Im Neuenheimer Feld 280

69120 Heidelburg

GERMANY

Dr. Henry Spitz

University of Cincinnati

8802 Castleford

Cincinnati, OH 45242

Dr. J. Newell Stannard

17446 Plaza Delores

San Diego, CA 92128

Dr. John Stather

National Radiologial Protection Board

Chilton, Didcot

OXON OX11 ORA

ENGLAND
Dr. Andrew F. Steheny

1132 Curtiss Street Apt. 2D

Downers Grove, IL 60515

Ms. Lynn Stembridge

HEAL

1408 W. Broadway

Spokane, WA 99201

Dr. E.T. Still

Kerr-McGee Corporation

P.O. Box 25861

Oklahoma City, OK 73125

Dr. Heather G. Stockwell, Director

Epidemiological Studies Div., EH-421, GTN

U.S. Department of Energy

Washington, DC 20585

Dr. Daniel J. Strom

Battelle, PNNL.

P.O. Box 999, MS K3-56

Richland, WA 99352

Dr. Casper Sun

Brookhaven Natl. Laboratory

Division of Rad. Science

Bldg. $703 \mathrm{M}$

Upton, NY 11973

Dr. Margery Swint

2426 Alexander Avenue

Richland, WA 99352

Dr. William G. Tankersley

Center for Epidemiologic Research

ORISE, P.O. Box 117

Oak Ridge, TN 37831-0117

Professor David Taylor

5, Branwen Close

Cardiff CF5 4NE

UNITED KINGDOM

Mr. Myint Thein

ORNL, 4500S, MS 6105

P.O. Box 2008

Oak Ridge, TN 37831-6105

Dr. James J. Thompson

University of Utah

Dept. of Radiological Health

100 Orson Spencer Hall

Salt Lake City, UT 84112 
Ms. Lisa J. Thompson

Westinghouse Savannah River Co. Medical Department - 719A

Aiken, SC 29808

Dr. MaryBelle Thompson, Director Empire Health Services

P.O. Box 248

Spokane WA 99210-0248

Dr. Robert G. Thomas

P.O. Box 279

Bigfork, MT 5991

Dr. R. E. Toohey

Medical Sciences Division

ORISE

P.O. Box 117

Oak Ridge, TN 37831-0117

Dr. Lois Travis

Natl. Cancer Inst. Radiation Branch

Executive Plaza North \#408

Bethesda, MD 20892

Dr. Normal M. Trieff

Division of Env. Toxicology

University of Texas Medical Branch

2104C Ewing Hall

Galveston, IX 77555-1110

Mr. Clinton Tuck

Health Effects Group

Rocky Flats Plant - Bldg. 122

Golden, CO 80402

Dr. I. Turai, Scientific Secretary

Division of Nuclear Safety, IAEA

Wagramerstrasse 5, P.O. Box 100

A 1400 Vienna

AUSTRIA

United Steel Workers Union, LU 8031

4510 Indiana St.

Golden, CO 80403

Dr. G. Van Kaick

German Cancer Research Center

Im Neuenheimer Feld 280

D-69120 Heidelberg

GERMANY

Veterinary Medical/Pharmacy Library

Washington State University

170B Wegner

Pullman, WA 99164-6512
Dr. George L. Voelz

Los Alamos National Laboratory

MS K404

Los Alamos, NM 87545

Dr. Niel Wald

University of Pittsburgh

Graduate School of Public Health

Room A-744

Pittsburgh, PA 15261

Dr. Ronald A. Walters

Pacific Northwest National Laboratory

ROB-3000 MS K1-50

Richland, WA 99352

Mr. Christian Wernli, Dipl. Phys.

Paul Scherrer Institute

Wurenlingem and Villigen

$\mathrm{CH}-5232$ Villigen PSI

GERMANY

Mr. Robert A. Wessman

TMA/NORCAL

2030 Wright Ave.

Richmond, CA 94804

Mr. C.M. "Hap" West

Oak Ridge Associated Universities

Oak Ridge, TN 37381-0117

Mr. Daniel White

Richland Field Office

US DOE, MS A7-80

P.O. Box 550

Richland, WA 99352

Dr. Gregg Wilkinson

Division of Epidem. \& Bio.

University of Texas Medical Branch

1.134 Ewing Hall

Galveston, TX 77555-1147

Dr. Robert W. Wood

U.S. Department of Energy

EV-31, Germantown

Washington, DC 20545

Miss J. A. Woodhouse

British Nuclear Fuels, Hinton House

Risley, Warrington WA3 6AS

UNITED KINGDOM

World Health Organization

Environment Health Criteria \& Stds.

1211 Geneva 29

SWITZERLAND 
Prof. McDonald E. Wrenn

Environ. Radiation Department

School of Medicine

The University of Utah

1771 South 900 West \#10

Salt Lake City, UT 84104

Dr. S.S. Yaniv

Office of Nuclear Ragulatory Research

Nuclear Regulatory Commission

Washington, DC 20555

Dr. Alvin L. Young

Radiation Research and Policy Coordination

1019 Nineteenth St., NW

Suite 700

Washington, DC 20036

Dr. Maria Limson-Zamora

Bureau of Radiation and Medical Divices

Dept. of National Health and Welfare

775 Brookfield Road

Ottawa, Ontario KIA ICI

CANADA

Dr. Paul L. Ziemer

School of Health Sciences

Purdue University

Lafayette, IN 47907

Dr. John D. Zimbrick

National Research Council

National Academy of Sciences

2101 Constitution Ave, N.W., Suite 342

Washington, D.C. 20418 